University of Rhode Island

DigitalCommons@URI

Open Access Dissertations

1981

\title{
Human Pharmacokinetics of 5-Formyl Tetrahydrofolate
}

Bruce Kenneth Birmingham

University of Rhode Island

Follow this and additional works at: https://digitalcommons.uri.edu/oa_diss

\section{Recommended Citation}

Birmingham, Bruce Kenneth, "Human Pharmacokinetics of 5-Formyl Tetrahydrofolate" (1981). Open Access Dissertations. Paper 141.

https://digitalcommons.uri.edu/oa_diss/141

This Dissertation is brought to you for free and open access by DigitalCommons@URI. It has been accepted for inclusion in Open Access Dissertations by an authorized administrator of DigitalCommons@URI. For more information, please contact digitalcommons-group@uri.edu. 
hoHAN PEARHACOKIMETICS OF

5-FOREIL TETRABYDROFOLATE

\author{
by \\ Bruce K. Birainghan
}

A DISSERTATION SOBEITTED IN PARTIAL FULFILLERT OF THE REQUIREEETIS POR THE DEGRE OF DOCTOR OF PEILOSOPHY

IN

PHARAACETICAI SCIBACES. -4 . S

URIVERSITI OF, RHODE ISLAND 1981

9 
ABSTRACT

The purpose of this study was to deternine the pharmacokinetics of calciua leucororin in normal subjects and in patients undergoing ingh-Dose methotrexace therapy for the treatnent of neoplastic disease. BY characterizing the disposition of leucororin it was hoped that the the efficacy of the nethotrexate therapy aight be inproved. while at the sane time, the incidence of toxicity could be dininished.

An assay for the separation and quantification of leucororin in serun was developed. The reduced folate was extracted from serun using reverse-phase chrowatographic ainicolunns and a paired-ion reagent. Leucovorin vas eluted fron this systen in methanol and eraporated to dryness nnder nitrogen. The extracted samples vere stable for 3 days when stored at $-40 \mathrm{C}$. High pressare liquid chronatography vas used to separate leucororin froa the extracted serum components using a reverse-phase. paired-ion mode. Ammonium phosphate, dibasic, vas found to be a suitable pairing agent. The recently developed radially conpressed reverse-phase colunns vere found to provide superior resolution of seru components than was possible with conrentional stainless steel colums. The 
effects of flov rate, pH, column temperature, and buffer concentration on the separation of leucovorin vere inrestigated.

Electrochenical detection was used to quantify the reduced folate in the extracted serun samples. An applied potential of 0.8 rolts was used to produce a sensitive and selective neans of detecting leucororin. The apparent lower linit of sensitivity under the conditions emploped was $12 \mathrm{ng}$ leucororin. The effects of $\mathrm{pH}$. buffer concentration, methanol concentration, and mobile phase flow rate on detector response vere investigated.

The protein binding of leucororin and its najor metabolite 5-methyltetrahydrofolate to human serum albunin was determined. over the concentration range of $5.0 \times 10^{-7}$. to 1x10-4 neither folate saturated the arailable binding sites. Leucovorin binding was a constant $70 \%$, while nethyltetrahydrofolate decreased slightly over this range. When both folates vere present in the albumin solution, there was a significant decrease in the degree of binding of each. Lethotrexate did not affect the binding of leucororin or its metabolite.

The pharnacokinetics of leucovorin was determined in 6 normal subjects and in 5 cancer patients. There vere no significant differences in the kinetic parameters calculated from either group. The disposition of leacovorin is best characterized by a two conpartuent open nodel. In initial half-life of $8.79 \pm 4.44$ minutes and a 
second. slover elimination phase of $231.46 \pm 31.76$ minutes was determined. The rolume of the central compartment was calculated as $5.49 \pm 3.53$ Liters. Leucororin serus concentrations in 3 cancer patients receiving aigh-Dose methotrexate vere deternined to be 3 to 11 tines greater than was predicted using methotrexate pharmacokinetic parameters.

This study clearly denonstrates that there are significant differences in the pharmacokinetics of leucororin and aethotrexate. The data presented in this study suggests that it aight be possible to reduce the anount of leucovorin administered to patients being treated vith methotrexate. This ma be expected to improve the efficacy of the antinetabolite therapy without additional risk of toxicity- 
TABIE OF CONTENTS

ABSTRACT ii

ACKNOULEDGEUENT T

TABLE OF CONTERTS VI

LIST OF TABLES Xi

LIST OF FIGURES xiii

I. IHTRODUCTION 1

II. IITERATORE SURVEY

A. Polate Chenistry 5

B. Leucovorin 8

1. Physical-Cherical Properties 8

2. Isolation and Identification 9

3. Biochenical Role 10

4. Clinical Applications 13

a. Megaloblastic Anemia 13

b. Reversal of Antifol Toxicity 14

5. Methotrexate 15

a. Physical-Chenical Properties $\quad 15$

b. Biochemistry and Pharmacology 15

c. High Dose Methotrexate Therapy 16

d. Pharnacokinetics $\quad 24$

i. Absorption 24 
ii. Distribution 25

iii. Uetabolisn 28

iv. Excretion 29

V. Pharmacokinetic nodels 30

6. Lencororin Disposition 31

a. Plasma 32

i. Intravenous 32

ii- Oral 36

b. Orine 41

c. 5-Methyl Tetrahydrofolate 42

1. Physical-Chenical Properties 42

2. Isolation and Identification 43

3. Biochenical Role 45

III. FOLATE ASSAYS 47

1. Microbiologic 47

B. Spectrophotonetric 48

1. 01traviolet 48

2. Fluorometric 49

C. others 49

IV. EC̣ETROCHEGICAL DETECTION 53

A. Theory 54

B. Electrode baterials 60

c. Cell Geometry and Operations 61

7. CGROGATOGRAPHI 63

VI. PROTEIX BIXDIHG 66 
A. Description of Protein-Drug Interactions

B. Equations Describing Protein Binding

C. Methods of studying Protein Binding

D. Polate Binding 74

1. Folic Acid 74

2. Uethyitetrahydrofolate 76

3. Leucororin 76

VII. EXPERIEERTAI

A. Materials and Methods 77

$\begin{array}{ll}\text { 1. Drugs } & 77\end{array}$

2. Reagents $\quad 77$

3. Chemicals 77

4. Equipment 79

B. Method 81

1. Electrochenical 81

a. Configuration 81

b. Electronic Connections 83

c. Electrode Preparation 84

i. Carbon Paste 84

ii. Glassy Carbon Electrode 85

2. Chronatographic 87

a. Apparatus 87

b. Solrent systems 87 
3. Protein Binding 89

a. Genbrane Preparation 89

b. Sample preparation 89

C. Oltrafiltration 90

4. Human Studies 92

a. Humans subject Protection 92

b. subject selection 92

c. Cancer Patients 93

d. Method of Blood Sampling 94

e. Extraction Procedure 96

VIII- RESULTS and DISCUSSION 98

A. Electrocheistry 98

1. Electrode Evaluation 101

a. Carbon paste, silicone-0il 101

b. Dax-inpregnanted Graphite 103

c. Glassy Carbon 105

i. Blectroactivity of Polate
nnalogs

ii. Durability 107

iii. Effects of Flow Rate 109

iv. Bffects of Salt Concentration 114

V. Effect of Methanol on Detector Response

B. Chroaatography

1. C-18 Stainless steel Columas 118

2. Radial Compression Separation Systen 126 
a. Bvaluation of Radial Compression system

i. Effects of Flow Rate

127

ii. Effects of Teaperature

128

iii. Effects of Counter-Ion Strength

131

iv. Effects of $\mathrm{pH}$

134

C. Drug Assay

137

1. Aqueous Systeas

137

2. Serun

138

a. Recovery

139

b. Sample stability

142

3. Separation of Lencovorin from serun Components

143

D. Protein Binding

151

1. Mon-Specific Binding

151

2. Analysis of Albunin Solutions

151

3. Leucovorin Binding to Human Serum Albunin

4. Leucovorin Binding to Botine Serun Albumin

5. Dethyltetrahydrofoalte Binding

6. Leucovorin-Methyltetrahydrofolate Binding Interaction

7. Leuco vorin-Hethyltetrahydrofolate Binding Interaction

vith lethotrexate 
E. Leucovorin Pharmacokinetics 167

1. Mormal subjects 167

2. Cancer Patients 176

3. Comparison of Leucovorin Pharmacokinetics Derived from uicrobiologic rersus Electrochenical Assay Methods

IX_ CORCIUSIONS

X. REFERENCES

XI. APPEUDICES

A. Institutional Berieu Board Approval

B. Hethotrexate Protocols and Informed Consent

C. Leucovorin Protocol and Inforned Consent

215

D. PORTRAM Subroutine DFUNC

220 
I. dethotrexate Protocols 23

II. Patient Information 95

III. Mobile Phase Conpositions 124

IV. Effect of Tenperature on Folate 132

V. Effect of Buffer Concentration on Folate Retention Time 135

VI. Recovery of Leucovorin from Serum 140

VII. Stability of Frozen Leucovorin Extract 144

VIII. Chronatographic Parameters Describing 146

Leucororin Separation fron Serum Components

IX. Leucovorin - Eethyltetrahydrofolate Binding Interactions

x. Methyltetrahydrofolate - Leucororin Binding Interactions

XI. Effect of lethotrerate on the Binding of Leucororin

XII. Effect of Methotrexate on the Binding of lethyltetrahydrofolate

XIII. Lencovorin Pharmacokinetic paraneters Derived fron 6 Mormal subjects

XIV. Comparison of Lencovorin Pharnacokinetic Parameters Between bales and Fenales

xV. Conparison of Iencororin Pharmacokinetic Parameters in Cancer Patients and Normal volunteers 
XVI. Comparison of Predicted and Calculated Leucovorin Serua Concentrations in

cancer Patients

XVII. Conparison of Pharmacokinetic parameters For J.eucovorin and Methotrexate

XVIII. Comparison of Pharmacokinetic Parameters Derived from a Microbiologic Assay and from an Electrochenical Assay 
1. Structures: Leucovorin, Hethotrezate. Folic Acid, Lethyltetrahydrofolate

2. Metabolic Pathways Involving Leucororin 7

3. Lencovorin Biosynthetic Pathways 12

4. Leucovorin Plasna Decay Assayed by a Hicrobiologic Disc Hethod

5. Diagran of the Electrochenical PlowThrough Cell

6. Lencovorin Byảrodynamic Voltamogram 99

7. Hethotrexate Hydrodynaic Voltamogram 100

8. Peak Height as a Punction of Applied Potential for Leucororin and Hethyltetrahydrofolate

9. Decline in Detector Response Heasured as Peak Height as a function of Tine

10. Effect of Dobile Phase Plow Rate on Ieucovorin Peak leight

11. Effect of Hobile Phase Plov Rate on Hethyltetrahydrofolate Peak Beight

12. Effect of Buffer Concentration on Leucovorin Peak Height

13. Effect of Buffer Concentration on Methyltetrahydrofolate Peak geight

14. Peak Beight as a Function of Hethanol Concentration in Injected Sample

15. Initial Leucororin Chromatogram

16. Resolution of Polate Analogs Using C-18 Stainless Steel Coluen 
17. Plot of Retention Time as a Punction of uobile Phase Plow Rate for Leucovorin and lethyltetrahydrofolate

18. Retention Time as a Function of Uobile Phase Flow Rate; LogLog Transformation

19. Effect of Column Tenperature on

Iencovorin and bethyltetrahydrofolate Retention Tine

20. Effect of $\mathrm{pH}$ on Leucororin and lethyltetrahydrofolate Retention Tine

21. Leucovorin Recovery from serun

22. Separation of Lencororin and lethyltetrahydrofolate Using the RCSS nodule

23. Serun Blank: Subject K. B.

24. Leucovorin in Serun: subject $\mathrm{K}_{-} \mathrm{B}_{\mathrm{m}}$

25. Percent of Leucororin Bound to Human Serun Albumin as a Function of Drug Concentration

154

26. Scatchard Plot for Leucororin: $r / a$ as a function of $I$

27. Percent of Leucovorin Bound to Borine Albunin as a Function of Drug Concentration

28. Percent of gethyltetrahydrofolate Bound to kuan serum albunin as a Punction of Drug Concentration

29. Scatchard Plot for bethyltetrahydrofolate: $\mathrm{I} / \mathrm{a}$ as a Function of $I$

30. Lencovorin Serua Concentration as a Function of rine: normal bales

31. Leucororin Serun Concentration as a Function of Tine: Hormal Females

32. Two Conpartment Open lodel 
33. Leucovorin Serum Concentration as a Punction of Time: Patient F.F.

34. Leucororin Serum Concentration as a Function of Time: Patient L.H.

35. Leucovorin Serua Concentration as a Function of Time: patient P.F.

36. Leucororin Seru Concentration as a Function of Time: Patient F.I.

37. Leucovorin Serum concentration as a Function of Tine, A Couparison Using pharnacokinetic Paraneters Derived fron Two Different Assay Procedures 
I. INTRODUCTION

The folate antagonist nethotrexate (MIX) is an effective antineoplastic agent widely used for the treatment of choriocarcinoma, osteosarcoma, and a variety of head and neck tumors (Stoller et alse 1977). It has also been used in non-neoplastic diseases such as psoriasis (Vanscott et alse 1964) systenic lupus erythenatosus (Svanson and schrartz, 1976), and psoriatic arthritis (Fosdick, 1968). Hethotrexate acts at the cellular level by reversibly binding the enzye dihgdrofolate reductase, preventing the reduction of dihydrofolic acid to tetrahydrofolic acid, thereby depleting the reduced folate pool necessary for the transfer of 1-carbon units in a number of biocherical pathways. As a result, DNA synthesis, porine synthesis, and sereral anino acid interconversions are severely inbibited (Bleyer, 1977). Lethotrexate's toxicity to normal and nalignant cells is dependent on both the administered dose and the duration of exposure (Djerassi, 1975 ).

since Parber first reported the successful use of an antifolate for the treatment of lenkemia (1948). ATX dosage 
page 2

schedules have changed dramatically. First used daily and given orally. progressively large: and more frequent doses (orally, intramuscularly, and intravenously) have provided consistently inproved clinical response. Djerassi has reported success in treating previously resistant tumors with MTI dosages in the range of 100-200 ing per where as little as $3 \mathrm{ng}$ per $\mathrm{m}^{2}$ had been employed. Bleyer (1977). Goldin (1978), and Djerassi (1975), have all discussed the historical background of high dose MTX therapY-

The goal of aTX research has been to identify the maximu dose and frequency of adninistration tolerated by normal tissues that will still be effective against tumor cells. Toward this end the pharmacokinetics of HTX have been extensively studied (Bischoff et alles 1971. Reich et ales 1977 and Huffinan et ales 1973) and the absorption. distribution, netabolism, and excretion of the drug in both animals and humans are well understood.

Leucororin (citrovoru factor, 5-formyl THF, LEO) is a reduced folate, capable of supplying 1-carbon units in the biosynthetic pathuags inhibited by MTI. since its further reduction does not depend on dihydrofolate reductase. Although the nechanisa by which leucororin "Iescues" a host organism is unknown. the prerailing theory postulates a conpetition for a conmon transport nechanisa regulating entry into cells (Chabner et ales 1975). As early as 1949 Burchenal et ale $(1949,1950)$ had reported the prevention of therapeutic effect of $\mathrm{MT}$ on nouse leukenia with the 
page 3

administration of LEO or pteroylglutanic acid. Goldin et ales $(1953,1954,1955,1966)$ and Bernbanu et ales (1965) working with leukenic aice produced results suggesting that proper administration of LEO subsequent to MTX could prevent toxicity in normal cells without protecting the malignant cells. Shoenbach et ales (1950) reported a case in which LEO was successfully used to reverse uTX-induced toxicity in a patient. Howerer, it was not until the work of Djerassi et allee $(1966,1967,1968,1970)$ and Lefkowitz et alee (1967) that controlled studies clearly demonstrated the role of IEU in preventing UT-induced toricity. Since the publication of these works, the cancer literature has been flooded with reports of improved clinical response in patients treated with high dose HTX-LEO rescue reginens. However, there is still considerable debate regarding the optinal dose and schedule of LEO which should be employed. Penta (1975), in a reviey of InD protocols discussed ten different treatment schedules while Nixon (1979) described a 100-fold range in the doses of IEO enployed and labeled current reginens as arbitrary.

Leucovorin has been assayed in hunan plasma biologically (dehta et alse 1978). radiochenically (Rothenberg et als 1979). radioimnuologically (Raso. 1977). spectrophotonetrically (Chapman, 1978), and by administration of radiolabelled drug (Nixon and Bertino, 1972). The applicability to pharnacokinetic analysis of each of these nethods, hoverer, has serere linitations. 
spectrophotometric methods are not sufficiently sensitive to reduced folates; microbiologic assays are generally not precise enough for pharmacokinetic analysis: radiochemical and radioimunologic techniques suffer from a lack of reproducibility: and the use of radiolabeled drug is inappropriate for the general patient population.

The pharmacokinetic data derired fron these methods is of linited value for two reasons. First, these studies have been carried out at relatively low doses and in the absence of nethotrexate, and, therefore, the do not reflect the clinical conditions under wich LEU is employed (1979) - Second, although plasma concentrations of LEU have been deternined, these studies were not adequately designed with regard to sapling time and duration of sampling for conplete pharmacokinetic analysis.

The parpose of this work is twofold: (1) to develop a rapid, sensitire, and reproducible assay for LEU in plasma and: (2) to characterize the disposition of LeU in normal subjects and in patients receiving high dose uT therapyDetermination of the pharnacokinetic parameters governing LEU distribution and elimination should make possible the optinization of LEJ rescue protocols without adversely affecting the anti-neoplastic activity of MTX. 
page

II. LITERATORE SURVEY

A. Folate Chenistry

The folates are a series of compounds containing the pteroic acid nucleus, conjugated with one or more L-glutamic acid molecules (Figure 1) (Blakely. 1969). Folic acid, $1-[\mathrm{p}-[$ [ (2-Amino-4-hydroxy-6-pteridingl)nethyl janino] benzorl]glutamic acid or pteroylglutamic acid (PGA). is a partially oxidized, stable form of folate found in pharmaceutical preparations but rarely in nature (Nixon. 1979). Folic acid is rapidly reduced, first to dihydrofolate (DHF). then to tetrahydrofolate (TBF) bI the enzyes dihydrofolate reductase and tetrahydrofolate reductase, respectively (1970). Tetrahydrofolate serves as an intermediate carrier of forml. nethyl. and hydroxynethyl one- carbon units, which are usually attached in the $\mathrm{H}^{5}, \mathrm{H}^{\circ} \mathrm{O}$, or MS-10 positions. These reduced folate forms are found in nearly all natural foods including manalian cells (Blakely. 1969). The so-called nfolate coenzyesn participate in a large number of enzymatic reactions in which one-carbon units are transferred frov one metabolite to another or alternatively may be interconverted to other coenzyne forms (1970). Figure 2 represents the netabolic pathways and interconrersions followed by folic acid and various folate coenzymes which result in the conversion of glycine to serine, homocysteine to methionine and deoxyuridine monophosphate (doup) to thynidglate nonophosphate (dTMP) and ultinately the 

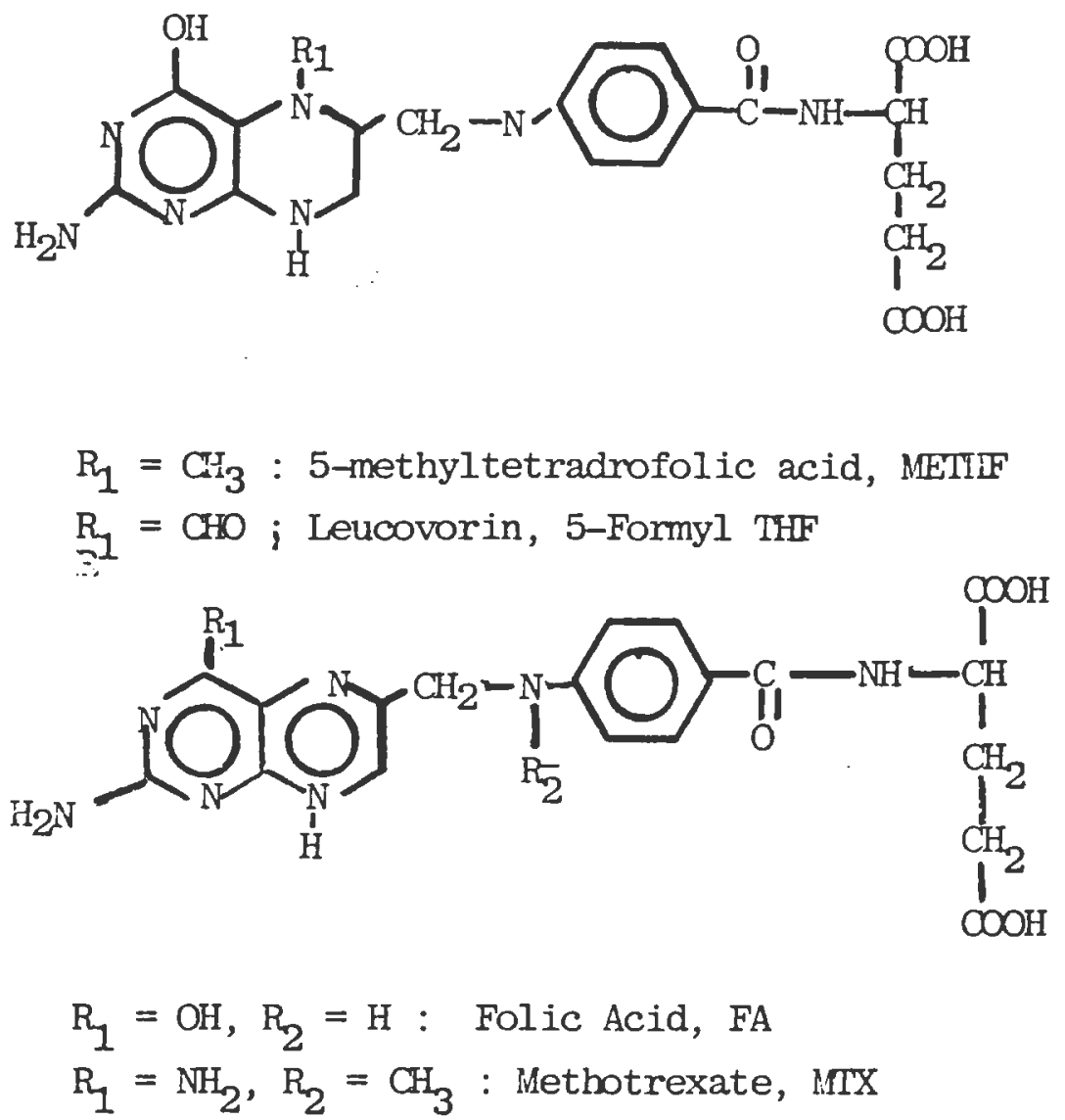

Figure 1: Folate Structures 


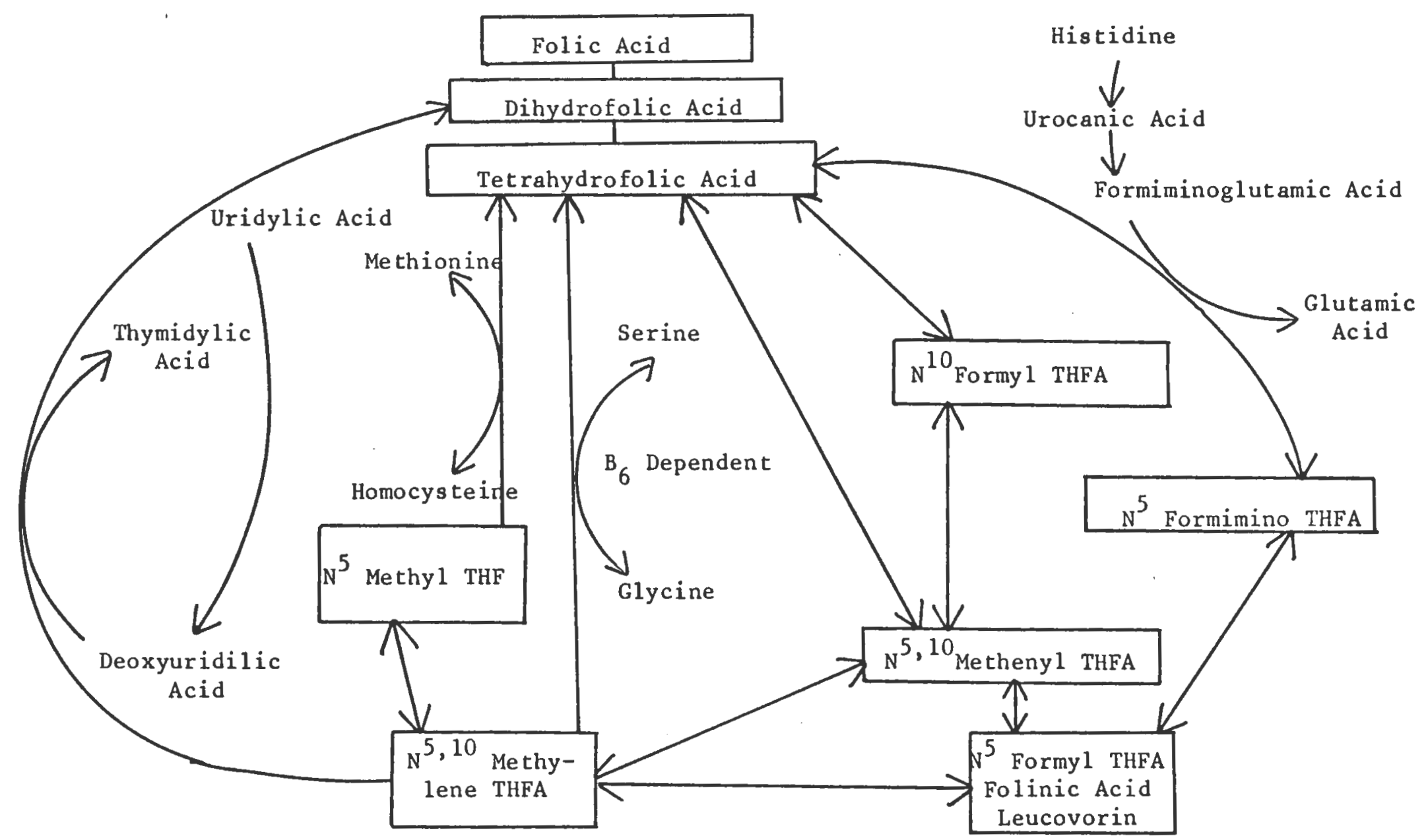

Figure 2: Metabolic Pathways Involving Reduced Folate Coenzymes 
page 8

synthesis of DaA. An excellent reviev of the biochenistry of folic acid, folate coenzyes, and related pteridines has been published (Blakely, 1969$)$.

\section{B. Leucovorin}

1. Physical-Chenical Properties

Polinic acid, $\mathbb{E}-[\mathrm{p}-[[$ (2-anino-5-form $1-5,6,7,8,-$ tetrahydro -4- hydroxy -6-

pteridingl) aethyl janino jbenzoyl]-L glutanic acid, molecular weight 511.513. is the formyl derivative of THF. It is one of the forms of reduced folate coenzymes found in the body. (Blakely. 1969). The tern leucovorin generally refers to the chemically syothesized material containing both the -I and 1 diastereomers. while "folinic acid" or "citrororua factor" applies to the biologically active 1 isomer only (Ponte et alles 1979).

Folinic acid (also called 5-formyl tetrahydrofolate)

is a rellowish-white or Yellow, odorless, microcrystalline powder (Blacow. 1972). It is sparingly soluble in water and practically insoluble in alcohol. The ptr of a saturated aqueous solution is 2.8 to 3.0 . at which partial deconposition takes place. Three pka ralues have been reported for the free acid: 3.1.4.8, and 10.4. The first two are attributed to the glutanyl carboryl groups and the third to the C-4 hydroxyl groap (Ponte et all=e 1979). The greatest stability is at neutral or gildly alkaline pH (Merck Index. 1976). The comercially available salt form 
page 9

of folinic acid, calcind leucovorin pentahydrate, molecular weight 601.513, is freely soluble in water but remains practically insoluble in alcohol (Herck Index, 1976). All the reduced folates are heat labile; folinic acid is. however, the most stable, and for this reason it is the only connercially arailable pharmacentical preparation of a reduced folate coenzyne (Kastrup and Boyd, 1980). An excellent review of the physical properties of leu inclading infrared spectrun, proton magnetic resonance spectrun. C13 nagnetic Iesonance spectrun, mass spectrum, x-ray crystallography. optical rotation and circular dichroise has recently been published (Ponte et ales 1979).

\section{LEO Isolation and Identification}

During a survey of organisms suitable for a nicrobiological assay of alanine. Sauberlich and

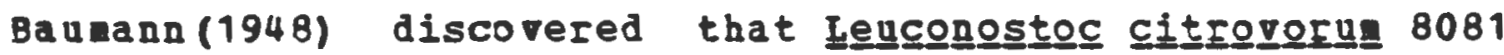
failed to grov on a nediua that had proved suitable for sinilar assay organisus. They also reported that various "antianenic" crude liver and yeast extracts promoted the growth of the organisa and did so at a substantially faster rate than did folic acid.

Keresztesy and silvernan (1950) reported the partial purification and concentration from liver of a "citrovorum-factor" so named because of its ability to stinulate the growth of $I_{\text {e }}$ citregrofune Brockarar et all (1950) and Bardos et ales (1949) reported the preparation 
page 10

of a compound resulting from the formlation and reduction of pteroylglutamic acid (folic acid), whose activity was sinilar to the extracted naterial.

Keresztesy and Silverman (1951), and Silverman and Keresztesy (1951), compared the actirity of the syathetic compound with the liver extract and found that the latter was approximately twice as active, relative to Is citcrovoran growth. It is now known that the synthetic naterial contains both the inactive dL and active IL diasteriomers. The naturally occuring extracted naterial contains only the active ll form, it is clear that, on a weight-weight basis, it would be more active than the syathetic material.

Pohland et ales (1951). proposed a structure for folinic acid-sf ("sf" designates a synthetic folate, as opposed to a liver extract as, 5-formy 1-5,6,7,8tetrahyiropteroyl glutaic acid, (Pigure 1). The synthesis fron either pteroylglutamic acid or formpleterl glatanic acid. (Roth, 1952) as the chenistry (Cosulich et ales 1952) of IRO have since been reported in detail.

\section{Biochemical Bole of LEU}

Leucororin was the first naturally occuring derivative of THF to be isolated, identified, and synthesized. (Blakely. 1969). Although the mechanism of its biosynthesis remains uncertain, three have been proposed (Figure 3): (1) the reverse of an ATP dependent 
page 11

conversion of LED to $\mathrm{N}^{5}$, HoO, methenYl THF and ADP + Pi; (2)

the reverse of a sieilar ATP dependent conversion of leucovorin to N10 forml THF + ADP + Pi; and (3) the formation of LEO and L-glutamate from $T B F$ and formylglutanate. (Donaldson and Keresztesy. 1959) Although the first tuo mechanisas are possible, they are not farored thermodynamically, and the third is limited by the quantity of fornylglutanate available (Blakely. 1969).

Lencororin is not believed to be involved in the direct transfer of one-carbon units in the biosynthesis of anino acids or the purine and prrimidine units of DNA. (Blakely. 1969) Bather, it erists in equilibriu with the gs, gro methylene, methenyl and weo fornyl folate coenzyes which are directly involved in sereral syntheses (lehninger, 1970).

The ajor role for LEO, although indirect, is in the syathesis of serine from glycine (Kislivk and Sakami.1955: Alexander and Greenberg, 1955; Blakely. 1954; and Blakely. 1957). Lencovorin confers the one-carbon (formyl) group on Hs, No-nethylene THF converting it to THP by donating the fornyl group to glycine, resulting in the formation of serine (Pigure 2).

The formyl group originating from LeO also participates in tro reactions important to purine biosynthesis. W5.N10 methengl THF donates the forml 1-carbon unit in the conversion of glycinamide ribonucleotide (GAR) to formlglycinamide ribonuclieotide 
1. 5-Formyl $\mathrm{THF}+\mathrm{H}^{+} \longrightarrow$

$$
5,10 \text { Methenyl } \mathrm{THF}+\mathrm{H}_{2} \mathrm{O}
$$

2. 5-Formyl THF + ÁP

$$
\text { 10-Formyl THF + ADP + Pi }
$$

3. 5-Formyl THF + L-glutamate

$$
\begin{array}{r}
\mathrm{THF}+\mathrm{N}-\text { formyl- } \\
\text { glutamate }
\end{array}
$$

Figure 3: Leucovorin Biosynthetic Pathways 
(EGAR) (Calabresi and Parks, 1975). Mto forml THF donates its formyl group in the conversion of 5-aminoinidazole carboxamide Iibonucleotide (AICAR) to

5-formando-inidazole-4-caboramide Iibonucleotide (FAICAIB) (Lehninger, 1970) - The syathesis of both fGAR and PAICAR are important steps in the biospnthesis of inosinic acid. and ultinately purine nononucleotides (Iehninger, 1970).

\section{Clinical Applications of LEO \\ a. Uegaloblastic Anemia}

Leucororin ay be used in the treatment of folate deficient megaloblastic anemias resulting from pregnancy. sprue, or nutritional deficiencies (A.S.H.P.. Leucororia Monograph, 1980)- Hoverer, LEO offers no advantage orer folic acid in treating these disorders and is considerably nore expensive. LEO may be useful in treating conditions of folate deficiency anemias in which the ability to reduce folic acid to the various coenzyme forms is impaired (A.S.H.P.. Ieucororin tonograph, 1980). Anemia associated wth acute portal cirrhosis (alcoholic or Laennecc's cirrhosis) often does not respond to folic acid therapy (Patek. 1969)- This phenonena has been attributed to an inability to produce reduced coenzyne forns rather than an actual lack of folic acid itself. It has been suggested in such cases that because of its ready conversion to other reduced coenzyme forms leo be used to treat the anemia (Patek, 1969). 
page 14

Tauro et ales (1976) reported tyo cases of megaloblastic anenia in infants resulting from a congenital deficiency of dihydrofolate reductase which prevented the reduction of dibydrofolate to THF. Both infants shored "satisfactory clinical response" following parenteral LEU therapy-

b. Reversal of Antifol Toricity

The najor clinical application of leucovorin is as an antidote for the folate antagonists pyrimetharine. trinethoprin, and methotrexate (A.S.H.P. Ieucovorin Gonograph, 1980). Pyrimethamine is a folic acid antagonist used in the treatnent of chloroquin-resistant malaria caused by susceptible strains of plasmodia (Marnan and Herbert, 1969) and nal be used to treat ocular toroplasmosis (Giles et alle 1964). It can produce negaloblastic anemia which, reportedly, has been reversed by IED but not by folic acid (Giles et ales 1964: and Darnan and Berbert, 1969).

Trinethoprin acts as an inhibitor of dihydrofolate reductase, blocking the production of THP (Kastrup and Boyd. 1980). Toricity resulting from trinethoprin therapy could presunably be treated by adninistering LEO and by-passing the point of enzime blockade. 


\section{Methotrexate}

The use of IEd in conjunction with nethotrexate (MTX) therapy represents the most important and videly studied application of a reduced folate in humans.

\section{a. Physical-Chenical properties}

Methotrerate, (amethopterin, UTX).

$N-[p-[[(2,4-D i a m i n o-6-p t e r i d i n y 1)$ methyl $]$-methyl amino Jbenzorljglutanic Acid, molecular veight 454.45 , is a yellow powder. structurally related to folic acid, scheme 1 (Herck Index, 1976). MTX is practically insoluble in water, alcohols, chlorotorn, and ether. It is freely soluble in dilute solutions of alkali hydroxides and carbonates (Blacow, 1972). The solubility of uT has been reported to be $2.2 \times 10^{-3}$ in urine at pH 5.1 and $2.2 \times 10$ -2 at pH 6.9 (Bleyer, 1977). MTX has two pka's; 4.8 and 5.5. attributable to the two carboxyl groups of the glutanic acid portion of the nolecule (Bleyer. 1977).

\section{b. Biochemistry and Pharmacology}

Hethotrexate, is one of sereral derivates of 2-4 dianopteridine which inbibit dibydrofolate reductase (Plenderheith and Bertino, 1975), the enzyme responsible for the reduction of dihydrofolate to tetrahydrofolate. This enzye block results in the depletion of THF and consequently the supply of folate coenzynes arailable for 
page 16

thymdylate and purise synthesis and the formation of serine and methionine (Calebresi and Parks, 1975 ). Thynidylate synthesis is reportedly the most sensitive to depletion of THF stores (Plenderheith and Bertino, 1975). As a result. DNA synthesis is affected to a greater degree than is RNA synthesis. Because DNA synthesis is most sererly affected, MTX's mechanisa of action is considered to be cell cycle specific, acting in the "s-phase" of mitotic activity (Bleger, 1977). In this manner, those tissues undergoing rapid cellular turnover with a high percentage of cells in "S-phase" are most suscepiible to the effects of घTX (Bleyer, 1977). The binding of MTX to the enzyme is considered to be of a "tight" but reversible nature (e.g.. it is a competetive stoichionetric inhibitor (Plenderheith and Bertino, 1975: Blakely. 1969). Johns et

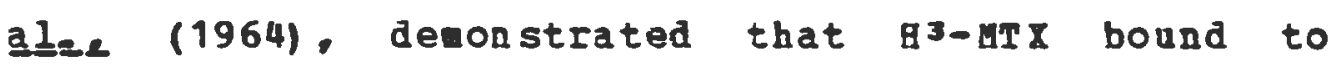
intracellular enzyue in man could be aisplaced to extracellular spaces by unlabelled MTX or by dibydrofolate. In addition to GT's affect on dihydrofolate reductase, Borsa and Mhitmore (1969), have suggested that uTX nay also act by difect inhibition of thymidylate synthetase.

Because the mechanisus for methionine and serine synthesis are disrupted by UTX, protein synthesis may also be affected (Bleyer. 1977). The author suggests that by this nechanisa uTX arrests cells in the $G 1$ phase of development and in so doing. protects those which survire 
UT exposure by slowing their progression in the s-phase. If hoverer, protein synthesis is discupted for long periods, cells will, of course, be seriously injured.

Goldman (1974) reported that for maximal suppresion of DUA synthesis, free intracellular methotrexate concentrations must be greater than those required to stoichiometrically bind with dihydrofolate reductase. The additional ETX is considered necessary to bind any new reductase which mag be synthesized, and to saturate a (proposed) second class of enzyae binding sites with a much lower affinity for MT (Goldin. 1974.1975). Chabner et ales (1973) and strauss and Goldstein (1943), howerer. suggest that these findings are compatible vith interactions between MTX and a single, high affinity site. In either case the requirenent for free intracellular MTX has been established. It is now generally recognized that the antineoplastic activity of MTX is dependent upon aintaining free intracellular levels above a threshold value which is specific for various tissues or tunor types) for prolonged periods and not simply peak plasma arx concentrations (Chabner and roung. 1973).

\section{c. High-Dose Hethotrexate-Leucovorin Rescue Regimens}

Parber (1948) reported the first successful treatment of cancer with a folic acid derivative when aminopteris vas used to proauce temporary remission of acute leukemia in 
page 18

children. Similar results vere reported by sacks et al=e (1950). With both aminopterin and UTX, in lov daily doses

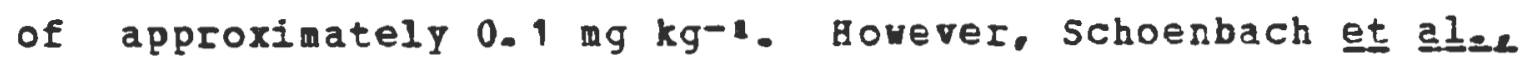
(1950) described a folic acid deficiency. caused by the antimetabolites. which was manifested by "gastrointestinal cramps, diarrhea, hemorrhage, ulceration of the palate and oral mucous membanes and leukopenia which may progess to an aplastic anemia and alopecian. Because the appearance of these toric nanifestations was frequently delayed, the cunulatire toxic dose might hare been exceeded before syaptoms occured. As a result, it has been suggested (Shoenbach et ales 1950) that sub-therapeutic doses of MTX night have been employed in an effort to prevent toxicity.

Early treatment schedules involving MTX usually required daily oral doses of 1 to $5 \mathrm{mg}$.. depending on the age of the patient (Acute Leukenia Group B.. 1965). rorking in wice with leukemia 1210, Goldin et ales (1956) experimented with different dosage schedules and found that drug administration every fourth day produced better results than did either vore frequent or less frequent adinistration. Based on these data, the Acute Leakenia Group B. (1965) compared intermittent parenteral adninistration to daily oral administration of MTX and found the new treatment schedule improved survival time in childhood leukemic patients. Hoverer, the twice weekly parenteral atx doses of $30 \mathrm{mg} \mathrm{m}^{-2}$ produced significantly more toxic symptoms than did daily oral dose of $3 \mathrm{ng} \mathbf{m}^{-2}$. 
Papac et ales (1967) used intrarenously administered uTX. $0.8 \mathrm{mg} \mathrm{kg}^{-1}$ in a single bolus injection every four days to treat squamous cell carcinoma. Although good clinical response was achieved there were frequent incidences of hematopoietic disorder, thereby limiting the duration of treatment.

The toric anifestations produced by UTX could not be reversed clinically with folic acid, crude liver extracts or vitamin B12. Folic acid, when giren prior to uTd (under certain conditions). has been used to prevent antifol toricity but the antineoplastic activity of MTX was also prevented (1950). When administered simultaneously or after MTX injection, folic acid afforded no protection from the toxic wanifestations of antinetabolite therapy.

The failure to reverse or eliminate bIX's toricity was a severe deterrent to optimal anti-metabolite therapy which had been proven beneficial in treating various forms of leukemia. Nichol and Nelch $(1950)$. reported that LEd had been used successfully to prevent the toxicity of aminopterin in both ice and rats. Schoenbach et al=z (1950) described the use of LEU to reverse aminopterin or anethopterin-induced nucositis in two patients under treatuent with daily oral doses. It was also reported that it vas possible to continue the antifol therapy while adninistering IEU to treat the induced toxicity.

Preclinical studies by Goldin et alled (1953). denonstrated that simultaneous administration of LEO 
page 20

reduced both the toxicity and antitumor effects of arx in both non-tumor and tumor-bearing ice. However, when it was administered in this manner. LEO actually reduced the surviral tine of aice that survired the initial drug toxicity. Further studies with murine L1210 leukenic mice confirmed that the prevention of toxicity is highly schedule-dependent and that delayed administration of IEU ight be therapeutically advantageous (Goldin. Vendetti, et al=e 1955). Goldin $\underline{\text {. }}$ alles (1953) denonstrated that delaying the adinistration of LED tuenty-four hours from the time of HIX dosing increased the specificity of action of amethopterin. reducing toxicity and allowing the employnent of higher uxx doses. Goldin et alles (1966) a:so reported that through proper scheduling of MTI with LEO rescue. it was possible to administer as much as $1000 \mathrm{gg}$ $\mathrm{Kg}^{-1}$ to tumor-bearing aice without toxicity, a dose which, without LEO, was toxic to all animals. The work of Goldin et alse $(1953,1955,1956,1966)$ clearly denonstrated the increase in the margin of safety for uTx when used in confunction vith the delayed adninistration of LEB.

On the basis of these findings, the LEO-rescue concept was extended to humans. Clinical studies in the treatment of metastatic osteogenic sarcoma (Jaffee et al=e 1974). head and neck tumors (Capizzi et alle 1970). leukemia (Djerassi, 1967). and other solid tamors (Djerassi et als=e 1972. Levitt et alee 1973) have since demonstrated the activity of high dose UTX-LEO rescue regiaens. To date. 
page 21

the dosages of LEO and MTX used, the length of the MTX infusion, and the scheme for LEO rescue vary widely between protocols and have been established largely on an empiric basis (stoller, 1978).

Recent work in tissue cell culture and sarcoma 180 murine tumor models has clearly shown a relationship between extracellular concentrations of MTX and IEO and the effectiveness of rescue. Penedo et ales (1976) denonstrated a competetive reversal of MTX cytotoxicity such that the toxicity produced by $10^{-7}$ M UI vas completely reversed by equimolar concentrations of LEU, but with higher MTX concentrations, relatively nore $L E O$ was required. For example, 10-sa MTX produced cytotoric effects in cell culture which vere not reversed until IEO concentrations reached 10-3M.: furthermore. it was not possible to reverse the toricity resulting from $4 T$ concentrations greater than 10-4 H. (Pinedo et al=e 1976). Sirotnak et al=e (1976). denonstrated a dose and schedule-dependence for LEU rescue during in plasma high dose uTX therapy of ascitic forms of $\mathrm{L} 1210$ and sarcoma 180. The authors noted that "schedules with rery delayed 'low-dose' LEO rescue following lethal doses of HTX were highly effective in preventing toricity and achiered a pronounced antitumor effect in both ascites tumor models". The best results vere reportedly obtained when LEU was withheld until 16 to 20 hours following ET, then adninistered every 2 hours for 5 doses. MTX was 
page 22

administered at a dose of $400 \mathrm{mg} \mathrm{Kg}^{-1}$ and $\mathrm{LEO}$ at $12 \mathrm{mg}$ $\mathrm{Kg}^{-2}$. Purther increases in MT doses did not substantially increase the anti-tuar activity: while progressively increasing the IED dosage reduced both the toxicity and anti-tunor effect. These data clearly suggest that manipulation of LEO dosage and schedule of administration can improve the therapeutic index of high dose uTx therapyBased on these observations, several clinical trials involving high dose MTX with LEO rescue have been andertaken. Table I shous some of the protocols which have been developed. Stoller et alee (1978) recently published a study (63) in which LEO was administered intravenously 30. 36, and 42 hours following an 18 hour MT infusion. Rather than use a standard LEO dose, the authors individualized the amonnt of LEO adninistered based on the plasma uTX clearance in the patient undergoing treatment. plasaa samples were obtained from patients and. using appropriate pharmacokinetic principles, the MTI plasma level at 30 hours post infusion was calculated. In this manner it ras possible to calculate an appropriate LEo dosage as well as identify as high risk patients, those individuals who vere not clearing aTz adequately. Although pinedo et alse (1976) had shown that at low MT levels (i.e. less than 10-7 ) equimolar concentrations of LED were sufficient to effect rescue. Stoller et alles (1978) elected to use a dose of IEO tenfold higher as a safety factor. The rolune of distribution, aistribution or elinination 
Page 23

TABLE I

METHOTREXATE PROTOCOLS

Methotrexate Dose (Lowest/Highest)
Delay Time (Hrs.) for CF Rescue
Dose \& Schedule of CF Rescue
非 - $100 \mathrm{mg} / 12 \mathrm{~g}$
1.5
6-25 mg q6h $\times 6-24-$ IM
非 $-240 \mathrm{mg} / \mathrm{m}^{2} / *$
NONE
$40 \mathrm{mg} / \mathrm{m}^{2}$ over $6 \mathrm{hrs}$, then $25 \mathrm{mg} q 6 \mathrm{~h} \times 4$ - IM
非3 - 200/500 mg/kg
4
$9 \mathrm{mg} q 6 \mathrm{~h} \times 12-0 \mathrm{ral}$
非 $-200 \mathrm{mg} / \mathrm{kg}$
2
$12 \mathrm{mg}$, wait $6 \mathrm{hrs}$, then $12 \mathrm{mg} q 6 \mathrm{~h} \times 11$ - IV, Oral

*Not Specified 
page 24

characteristics of LEU have not been reported, therefore. these authors assumed that, since MTI and LEO are structurally related, LEO pharmacokinetic parameters were identical to those of MTX. Jsing this approximation, they were able to minimize the LEU dosages employed and reduce the incidence of myelosuppresion in patients to less than 3 percent, thus demonstrating that careful pharmacokinetic nonitoring could improre the therapeutic index of aTx.

\section{d. aTX Pharmacokinetics}

i. Absorption

Henderson et alse (1965) Ieported that B3-4rx. adninistered as a solution, was completely absorbed at a dose of $0.1 \mathrm{gg} \mathrm{Kg}^{-1}$. Freeman (1958) also found the drug to be completely absorbed following the oral adninistration of $30 \mathrm{ng}$. of ITX. Peak plasma lerels are reportedly achiered vithin one to four hours of oral doses. Man et al= (1974) described evidence which suggested biliary secretion and subsequent reabsorption of Mx. These authors found peak plasma concentrations following a $30 \mathrm{gg} \mathrm{m}^{-2}$ oral dose to be lower than those achieved when the identical dose was adinistered intravenously. Furthermore, the area under the plasna concentration -time curve was approximately $47 \%$ that of the intravenous dose. These authors also determined, via urinary excretion data, that approxinately 88\% of the administered dose was absorbed. Burchenal et alㅡㄹ (1956) reported a loyer figure, approximately 40 of 
page 25

the drug was recovered in urine within 24 hours of a $5 \mathrm{ng}$. oral dose.

When MTI was administered orally at a dose of $80 \mathrm{mg}$ $n^{-2}$, absorption was erratic and incomplete (Henderson et alles 1965 and Man et ales 19741. At this dose only $31 \%$ of the drug was excreted in the urine, while fecal excretion increased from approximately 1\% following an intravenous dose to almost $30 \%$.

These data have led Bleyer (1977) to conclade that the absorption of aTX may involve a saturable intestinal absorption mechanism, possibly including an active transport mechanism.

In adition to absorption from the gastrointestinal tract, STI absorption into plasaa from the central nerrous systen has been reported. MTI is used for the treatment of meningial leukenia and may be adninistered via rentricular or lubar injection (Shapiro et alles 1975). Jacobs et al $I_{=}$ (1975) reported that the administration of 10 to $15 \mathrm{mg} \mathrm{m}^{-2}$ intrathecally. Iesulted in plasma concentrations abore 10-0 a. two to three times longer than the sane dose adinistered intravenously.

\section{ii. Distribution}

The disappearance from plasma of intravenously adninistered ur has been described both as biphasic and triphasic. Huffman et alles (1973) reported an initial half-life of $0.75 \pm 0.11$ hr.. most likely due to 
page 26

distribution. Stoller et ales (1975) and pratt et alle (1974) failed to detect such an early distributive phase because of inadequate plasma sampling immediately after drug adinistration. The second half-life reported by Huffman et alee (1973) corresponds well with the first phase half-life of stoller et alses (1975) and pratt et ales (1974) and is between 2.0 and 4.0 hours. This half-life is attributed to renal clearance (Bleyer, 1977). The third and final phase half-life, attributable to biliary recycling, has been reported as $10.4 \pm 1.8$ hours by stoller et alee (1975) and as $26.99 \pm 4.44$ hours by Huffoan et alles (1973). The discrepancy in the terninal phase half-1ife nay be due either to differences in dosing schedules. or, the assay nethod used to measure MIX (stoller et alles 1975). The third phase has been implicated in the toxicity associated with high dose-MTX regimens (Djerassi, 1975). These observations suggest that the toxic effect of $M T X$ on normal tissue is primarily a function of the duration of exposure to suprathreshold concentration of of drug. Iather than the peak plasma levels which way be achiered (Bleyer. 1977).

unffaan et ales (1973) calculated two rolumes of distribution for ar: an initial distribution volume was reported as $13.8 \pm 1.09 \mathrm{~L}$. which is considerably larger than the plasma rolume and indicates rapid tissue distribution of uT. The second value reported was the apparent rolume of distribution at steady state which was 
page 27

$73.3 \pm 15.6$ liters.

Methotrexate has been shown to be protein bound. primarily to serum albumin. Man et ale (1974) reported a mean of $45 \%$ of plasma urx bound to protein in twelve patients with drug concentrations between 0.3 and $3 \mathrm{mg}$. 1.-2. Liegler et al. (1973) deternined urx plasma protein binding to be betreen 50 and $70 \%$ in a group of fifteen patients. Taylor and Halprin (1977) also found

approxinately $60 \%$ of serum MT bound to albumin. In a more recent publication, steele et $\underline{a} 1=$ (1979) reported aTX binding to albunin to be approxinately $87 \%$ and to total plasma protein: 95\% orer a concentration range of 1 to 30 micromoles 1-. These authors also performed scatchard analysis on their data and determined that urX binds to two distinct classes of binding sites (steele et alee 1979). The displacement of uTx from its protein binding site(s) has been demonstrated with both para-aminohippuric acid (Liegler et ales 1970) and salicylic acid (Taylor and Halprin, 1977).

Lethotrexate, videly distributed in body tissues, is concentrated in the liver: liver to plasma ratios of $8: 124$ hours after intravenous administration of $80 \mathrm{ng} \mathrm{m}^{-2}$ have been reported (Creaven et alee 1973). Dedrick et alle (1973) reported, for the rat, tissue:plasma partition coefficients of 3 and 1 for the liver and skin respectively. Distribution into interstitial fluid spaces: cerebrospinal fluid. pleural, and peritoneal cavity occurs 
page 28

slouly. with characteristics described by Bleyer (1973) as resenbling a passive transport systen. Transport across cell membranes is achiered via an energy-coupled carrier mediated mechanism which has been described in detail (Flament-Durant, 1975 and Hall et ales 1966). One of the reasons for employing high dose-MTX reginens is to produce plasma drug concentrations sufficiently heigh to permit facilitated diffusion into tumor cells deficient in transport sites (Bender et al=ㄹ 1977).

\section{iii. Metabolism}

Early studies of uTX administered at "conrentional" doses suggested that, in man, the drug is excreted unchanged into the urine (Henderson et alles 1973). Man et al- (1974) detected a netabolite of MTX excreted in the arine which accounted for approximately $6 \%$ of a 30 g. $m^{-2}$ intravenous dose. Following oral adainistration of the sane dose. $35 \%$ of the drug was excreted in the form of netabolites (Man et als 1977). It has also been shown that $\Delta \mathrm{TX}$ is netabolized during enterohepatic circulation by bacterial organisms within the gastrointestinal tract (Bleyer, 1977). These reports suggest that BIX metabolism in man occurs primarily in the gastrointestinal tract or "enterohepatic circuit" (Bleyer. 1977). Jacobs et alle (1976) discovered that humans excrete "significant" anounts of 7-hydroxymethotrexate when doses of MTX greater than 50 m Kg.-t are administered intravenously. The discovery of 
page 29

this metabolite is significant because of its extremely low aqueous solubility which has been implicated as the cause of renal toricity often associated with high dose nTX regimens (Jacobs et ales 1976).

\section{iv. Excretion}

Excretion of uTX is primarily renal. Huffman et ale (1973) reported that ninety-six hours following intravenously adninistered MTX. $66 \%$ to $81 \%$ of the adninistered dose was excreted unchanged. The remaining $19 \%$ to $34 \%$ was accounted for by various netabolites. Buffuan also reported a renal clearance rate of $78 \pm 4.9$ 1. nin-1 for "low" plasma concentrations of UTX. This report indicates that $\mathrm{MT}$ is reabsorbed since the renal clearance was less than the glomerular filtration rate in the patients studied. The clearance of UT at "high" plasma concentrations was significantly higher than inulin clearance in 13 patients, suggesting active secretion of the coepound (Liegler et ales 1970). Approxinately 1.5\% of an intravenous dose appears in the feces, nost likely caused by excretion of MT from the liver into the bile (Huffnan et alle 1973). These authors also reported that sone patients showed two or three increases in the rate of MTI excretion during a 96 hour urine collection period. since these increase were associated with ingestion of food. it was suggested that uTX undergoes substantial biliary secretion and subsequent reabsorption (Huffaan et 
ales 19731.

e. Pharmacokinetic nodels

The use of mathenatic models in relation to drug disposition is inportant in formulating generally applicable predictions of plasma concentrations before drug is administered. In an effort to predict UTX plasma levels in man. sereral nodels describing its disposition have been developed.

stoller et $\underline{\text { al }}=$ (1975) used a two compartment open nodel. based on Equation 1 to describe MTX.

$$
\mathrm{Cp}=\mathrm{Ae}-\alpha t+B e^{-\beta t}
$$

(Equation 1)

Huffman et al- (1973) found that plasma concentration-tine data could best be described by a three compartment open model and the corresponding tri-exponential equation.

$$
C p=A e^{-\alpha t}+B e^{-\beta t}+C e^{-\gamma t}
$$

(Equation 2)

Reich (1977) has developed an expanded model consisting of seven distinct corpartments including shallor and deep intracellular spaces, netabolite space, metabolite extracellular space and urine. An interesting aspect of this model is the inclusion of Michealis-Menton kinetics to describe appearance of drug in the urine, hoverer, the 
page 31

adrantage of such a complex model over the previously described. simpler odels has yet to be demonstrated.

Bischoff et al 1 - $(1970,1971)$ have developed a "physiologic-perfusion" nodel to characterize the dispostion of MTX. Contrary to compartments with little or no physiologic meaning, the perfusion model is composed of specific body regions with similar physiologic characteristics such as blood flov, and drug:tissue partition coefficients. The significance of perfusion models is in their ability to Ieflect physiologic conditions which affect drug dispostion whereas lumped compartments are not suitably flexible for this purpose.

6. Leucororin Disposition

Although the general disposition of orally or parenterally administered LEO has been determined, there have been no published reports which quantitatively characterize its pharnacokinetics, either alone or in combination with high-dose ETX therapy (Nixon, 1979). The majority of published data wich include IEJ's disposition. is prinarily involved with its rate of conversion to HETHF, the major component of naturally occuring, circulating serun folates (Herbert et alles 1962). Purthernore, much of these data are of a qualitative, rather than a quantitative nature, consequently. pharacokinetic interpretation of these rorks is not possible. 
page 32

\section{a. P lasma}

i. Intravenous

Spray and litts (1953) were the first to examine, in huans, the rate of disappearance of intravenously adeinistered IEO in normal subjects and patients suffering from "anemia". Following injection of $1.0 \mathrm{ng}$, peak plasma levels neasured 10 ninutes after dosing, varied from 44 to $76 \mathrm{ng}$ n-t in normal subjects, and 33 and $54 \mathrm{ng}$ i-t in anenic patients. The authors made no statistical inferences regarding this data. The rate of disappearance of LEO was described as "rapid", plasma levels were less than 10\% of maximu within $1 / 2$ to 2 hours after dosing. No differences in elimination rate between normal and anemic subjects was noted. These authors reported a "folinic acid-space" which was calculated by dividing the total amount of LEU in the body by the corresponding plasma concentration. Two such spaces were reported; 10 minutes and 90 minutes post drug adnistration. st 10 minutes, the ralue of this space had a mean value of 17.2 liters in normals and 24.2 liters in anemia patients, which denonstrated a statistically significant more rapid uptake in the anemia patients. The space calculated at 90 minutes for controls and anenia patients was 342 liters and 547 liters respectively. Howerer, the meaning of this space is unclear. since it may reflect either the conversion of IEU to other folate forms or, that IEJ is quickly taken up by 
page 33

tissues. A representative plot of drug concentration as a function of time from the normal subjects is shown in Pigure 4. Baker et allee (1965). Characterized the fate of parenterally administered "folinic acid" (LEO) by determining plasma folate activity from $\underline{P}_{2}$ cerevisiae growth. Because a "great increase" in this organisn's growth was observed. these authors concluded that "parenterally administered folinic acid circulates unaltered".

The disposition following intrarenous adninistration of 5 ug $\mathrm{Kg}^{-1}$ of double radiolabelled folinic acid (5-foray $1-2 \cdot C-F B 4-3 B)$. in a human patient was described by Mixon and Bertino (1972). Serum collected 90 minutes after dosing revealed that $40 \%$ of the radiolabel co-chronatographed with a folinic acid marker. sixty percent of 3 B label was present as METHF, denonstrating conversion of LEO to the predominant circulating folate. The remaining markers had been "labilized to non-absorbable naterials, perhaps anino acids" suggesting that little IEO remained in the circulation ninety minutes after dosing.

In a nore recent study. Rothenberg et allel (1979). characterized the plasma clearance of LEO following rapid intrarenous injection in two normal subjects. The radiochenical assay measured both the active and inactire diastereoisoners of IEU. Peak plasma concentrations achieved in those two subjects following doses of $6.0 \mathrm{mg}$. and $3.0 \mathrm{gg}$. vere approximately $1100 \mathrm{gg} \mathrm{ml}-\mathrm{z}$ and $1000 \mathrm{ng}$ 


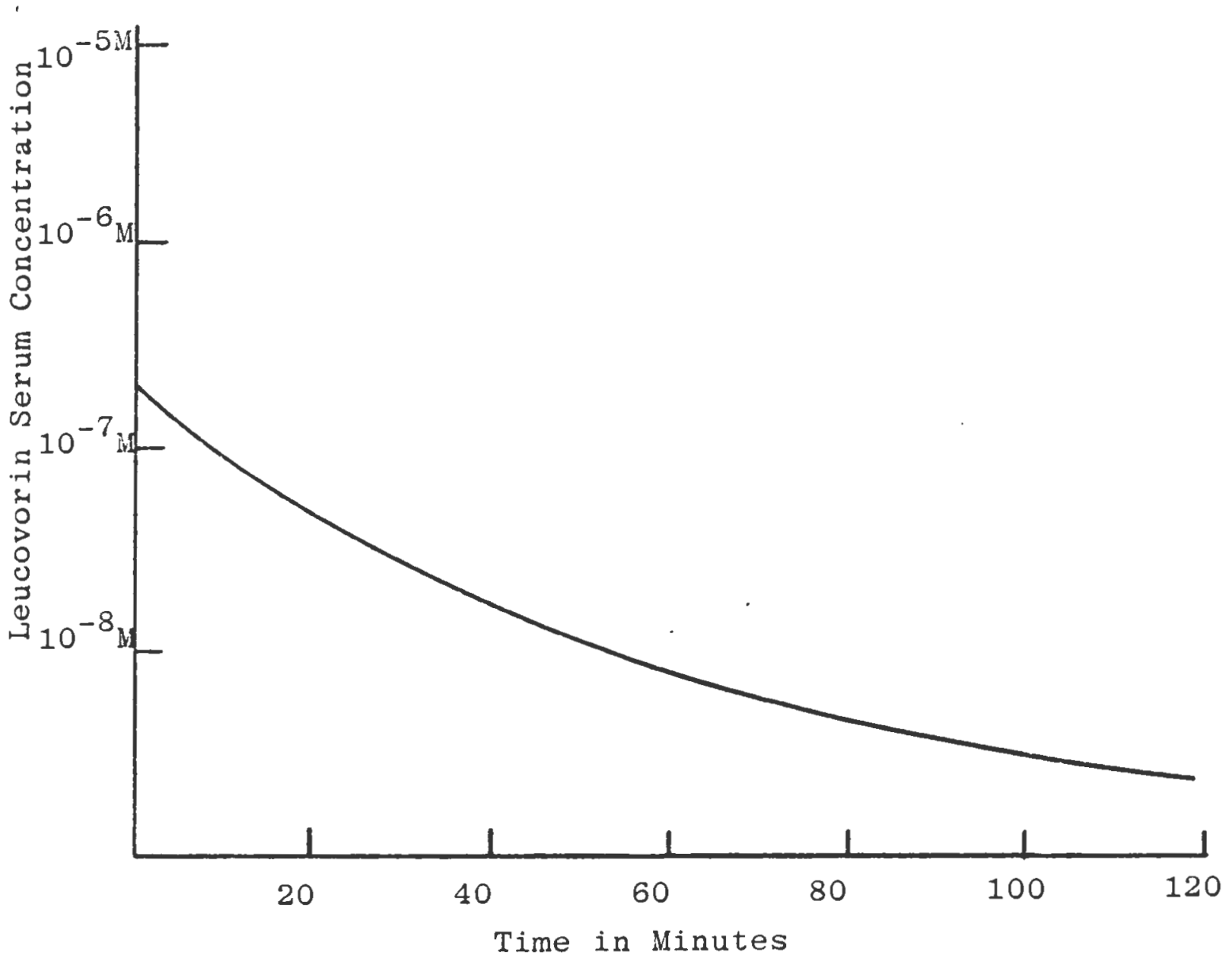

Figure 4: Leucovorin Plasma Decay as a Function of Time as Measured by a Microbiologic Assay Method 
page 35

m- respectively. The plasma profiles showed a "rapid clearance for the first 30 minutes" which "then plateaued and cleared very slowly over the next 90 ainutes". The description of a platea following the rapid initial decline in plasma LEJ is contrary to the reports of spray and Nitts (1953) and Nixon and Bertino (1972) who described only a rapid plasma clearance with no nention of a second elinination phase. Rothenberg et ales (1979) suggest the slow second phase clearance is nost probably due to the accumulation of the inactive diastereoisomer, since the kidney appears to preferentially excrete only the active fOIn of LED.

Perry and Chanarin (1970). Chanarin and Perry (1970). and uclean (1967), have performed a series of experinents designed to deternine the origin of seru uETHF after the intravenous administration of tritiun labelled folato analogues. These authors reported that "uhen given parenterally...these conpounds exchange with folates in body tissues, that is, when tritium-labelled dihydrofolate or tetrabydrofolate.... is given by injection the labelled folate disappears frov plasma and is replaced by an anlabelled fora...". Furthernore, Johns et ales (1961) reported that "when a parenteral dose of trician-labelled folic acid in an was followed by a large dose of non-radioactive folic acjd 24 hours later, a large anount of radioactivity was displaced...".

These data suggest that the appearance of METHF in 
page 36

plasma following the intravenous administration of LEU is caused by a flushing of METHF from tissue rather than a airect netabolic conversion.

ii. Oral

The fate of orally administered folates, including LEO has received considerable attention. specifically, the rate at which folic acid crosses from the gut into the circulation and the rate and extent to which folates are converted to artar, the predoninant circulating reduced folate analog (Denko.1951: Spray and Nitts, 1952; Chanarin. Anderson, and tollin, 1958). In addition Blakely (1969) has published an excellent raview of folic acid biochenistry which includes the disposition of orally adninistered folate. Although the fate of orally administered IBO has received considerably less attention. interest in this route of adninistration in MTI-rescne regimens has prompted relatively recent interest in its disposition.

Baker et alle (1965) administered 10mg. of racemic folinic acid to 48 normal subjects. Assay of serun folates was carried out by a combination of TIC and the standard microbiologic assay technique of Sauberlich and Baunan (1948). Serum folate activity ( Le Caseil indicated a slow rate of absorption, the peak activity was not reached until 4 hours after administration. followed by a rapid decline in activity at 8 hours, the last samping time. Because 
little or no activity was noted for either s= faecalis or

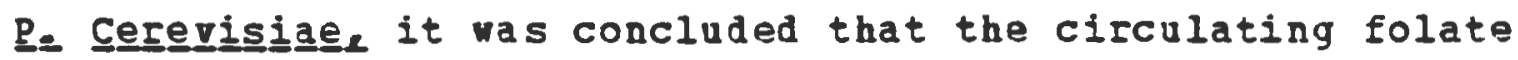
was not LEO but rather uETHF wich vas rapidly converted frov LEU in the intestine.

Perry and Chanarin (1970) noted that, with the exception of Baker et allel (1965). almost all previous reports concerning the intestinal absorption of folates dealt with folic acid alone. These athors reported the absorption of the reduced folate DHF and THF as vell as their formyl and nethyl derivatives. The evidence presented in this paper suggest that DHF is first reduced to THF and then aethylated in the small gut during its intestinal absorption. Furthernore, "...tetrahydrofolate which is already reduced is methylated". It is suggested that the enzyme dihydrofolate reductase is involved with these reductions in the saall intestine. The selectivity of this reduction is denonstrated by the rapid conversion of DHF to THF conpared to the reduction of folic acid to DHF wich is reported to occur at approximately one-tenth the rate of the former reaction (Zakrewski and Nicol. 1960). Thus, it was reported that the reduced forms of folate, including IED, were completely reduced to THF and nethylated. whereas folic acid was only partially reduced.

Thithead et alle (1972) described the intestinal conversion of $2 \mathrm{ng}$. of racenic $2 E 0$ to UETHF in 3 subjects. Osing the standard icrobiologic technique, folate activity was measured in both the peripheral venous plasma and the 
page 38

hepatic portal venous plasma. These authors defined newly absorbed folate as "the difference between the increment of folate actirity in hepatic portal vein plasma and in systenic plasman. Although the data is not suitable for pharmacokinetic analysis certain trends are evident. Peak folate activity was reached betreen 30 and 60 ginutes of adninistration in all 3 subjects. However, the rate of drug clearance anong the subjects varied greatly. The half-life was estimated as 45 minutes in one subject, 15 minutes in the second, and in the third a plateau in plasma concentration vas observed making an estimate of half-life inpossible. In agreement with perry and chanarin (1970). the predoninant circulating folate found in plasma was not LEO but rather, utrBP, indicated by an increased $L=$ casei activity and little activity for either $\mathrm{P}_{2}$ cerereyisiae or $\underline{S}_{=}$ faecalis: A small amount of plasma folate active for these organisms vas found early in the course of absorption. Whithead et alse (1972) suggest that a small amount of folinic acid nay have reached the plasma ria passive absorption with water through the intracellular spaces. The appearance in plasma of HETHF, measured by Le casei activity. following LEU aduinistration was also observed by pratt and Cooper (1971). However, $S_{2}$ faecealis and $\underline{p}_{-}$ cerereisiae activity was seen in plasma 30 minutes after dosing. suggesting that some IED had been absorbed. Thin layer chromatography of serua samples confirned that this folate was indeed IEU (Pratt and cooper. 1971). The 
page 39

absence of an increase in $p_{\text {. }}$ cerererisiae actirity in the bile was taken by these authors to mean that little if aIy LEO appeared in the bile. Rather, it is concluded that folates appearing in bile reflect the "intracellular folates of liver", and not orally absorbed analogs.

IEU is known to form, under the acid conditions existing in the stomach, Ns-No methengl THF which in turn forms, in the basic environgent of the sall intestine, the readily oxidized and unstable wo formy THP (Hay and Bardos et ales 1951). Because the suitability of Nio formyl THF for rescue following high dose-MTX has not been established, LEO has been used parenterally in IEscue protocols (Nixon and Bertino, 1972)-Nixon and Bertino (1972) used radiotracer techniques to determine whether orally administered LEO reached the blood pool in a form that "contributes to expand the body pool of reduced folate coenzymes and so potentially to reverse the effects of antifolates". At doses of this conpound as high as 50 ug $\mathrm{Kg}^{-1}$. oral absorption was "close to 90 percent". since only 8\% of the ${ }^{3} \mathrm{H}$ and $5 \%$ of the $14 \mathrm{C}$ was excreted in the stool within five days of drug administration. During transfer from the gastrointestinal tract to the systeaic circulation substantial metabclis. of LEO occured. Ninety percent of the serun folate $3-$ a was identified as labelled utgr. while that label associated with the itc-forill group did not appear among the circulating serum folates, suggesting that this portion had been taken up by tissues. 
page 40

These data taken with the previously described work of Dhithead Et alse (1972). Perry and Chanarin (1970, and Baker (1965). demonstrate that orally administered LEO raises levels of serun folate activity for L- casei but not $\underline{\text { S}}$ faecalis or $\underline{P}_{-}$cererisiage, and identifies METHF as the predominant circulating folate. Because METHF can circunvent the enzyne block inposed bY MTX, these works suggest that orally administered LEO nay be aseful in high dose-MTX reginens.

Wehta et alse (1978) recently investigated the serun distribution of LEO following oral administration of $15 \mathrm{mg}$. of drug as a solution and as a tablet. Nithin 30 minutes, of oral administration, 90\% of the adninistered folate vas assayed as METHP. Peak plasma levels of LEO vere observed 30 minutes following dosing and fell off rapidly afterwards. The plasma half-life of LEO was reported as $0.64 \pm 0.07$ hr. and $0.67 \pm 0.07$ hI after oral liquid and oral tablet administration respectirely. Fron these data. it vas further observed that peak nETHF levels were achieved approxinately 2 hours folloving the administration of drug. HeTEF was deternined to have a half-life of approximately 2.2 hours.

The reported IEO half-life of 0.67 hr is in general agreenent with the values of 30 minutes reported for the elimination phase half-life deternined by spray and (1953). The fact that Mehta et alse (1978) did not describe a distribution half-life is most likely caused by 
page 41

difficulties in detecting rapid distribution following oral drug administration (Hagner, 1975).

\section{b. Orinary Excretion Data}

The renal excretion of folic acid has received considerable attention ( Hclean and Chanarin, 1966: Goresky et alee 1963: Chanarin and tclean, 1967). and has been reviewed by Blakely (1969). DETHF, N10-formyl THF and M5, Nio-nethenYl PH4 are the nost connonly detected urinary folates. There is howerer, a pacity of data dealing specifically with urinary excretion of LEO.

spray and Mitts (1953) followed the urinary excretion of LEO following the intravenous administration of $1 \mathrm{mg}$. of drug to 5 nornal subjects. The percent of drug excreted during the first two hours after dosing ranged fron 9.9 to 19.2. and had an arerage value of 15.4. No folate activity attributable to LEO was observed after 2 hours, indicating either conversion to another form or uptake of the drug by various tissues.

Mixon and Bertino (1972) found a "fairly-constant" rate of urinary clearance of M10-formyl and N3. Noo methenYl Fa4 following the administration of double radio-labelled LED. In addition, these authors reported that the portion of urinary ueTHE was approximately proportional to the serua concentration of identifiable radio-labelled METHP. Purthermore, "large anounts of radio-labelled 5-formyl" PB4 vere found in the urine $0-2$ hours post dosing. even when no 
page 42

corresponding label was identifiable in the serum. In a sinilar study of administered radio-labelled uETHF, no formyl folate was excreted in the urine (Nixon and Bertino 1970). These data led the authors to conclude that the "... kidney may have both regulatory and netabolic roles in the excretion of folates: serum 5-methyl FB4 may be conserved by the kidney in preference to 5-formyl PH4...".

Recently, Rothenberg $e^{t}$ alles (1979) exanined the urinary clearance of LEJ in a subject wo receired 3 . of intrarenously administered racemic LEJ. The total urinary excretion in two hours was calculated to be 578 ug or $19.3 \%$ of the adninistered dose, a value that is in general agreenent with the earlier work of spray and Mitts (1953). The arinary excretion of LEO in two subjects receiving only the actire isomer of LEO was also determined. The two hour cunulative urinary excretion in the 2 subjects vere $16.6 \%$ and $20 \%$ of the administered dose. It was concluded from these data that since the percent of dose excreted following the administration of either the racenic mixture, or active diastereoisoner, of LEJ were similar that only the actire rather than the inactive form is rapidly excreted.

C. 5- Methyl Tetrahydrofolate

1. Physical-Chemical Properties

Prefolic A (5-methyl THF, METHF), N-anino-5-methyl $5,6,7,8,-t e t r a h_{Y}$ ro- 4-hYdroxy-6-pteridingll methyl 
page 43

aninobenzoyl L-glutamic acid, is a yellowish white or uhite crystalline powder. The anhydrous barium salt has a aolecular veight of 594.8, comercial preparations usually contain four molecules of vater per mole of compound (sigma Product Catalog. 1980). The aqueous solubility of METHP has been reported as 1.1 grass per 100 . 1 . It is practically insoluble in organic solvents (Conti et alee 1974). The nelting point of METHP is reported as greater than 3000C. (Conti et alse 1974). At alkaline pH, UETHF is easily oxidized by air or hydrogen peroxide-perioxidase to a dihydrofolate (Gupta and Huennekens, 1967). Which in turn, can be reduced back to MeThp by hydrogen in the presence of platinum. ascorbic acid or borohydride (Blakely. 1969).

spectral characteristics for METHF, in phosphate buffer $\mathrm{pH} 7.0$, have been reported (Blair and saunders. 1977: Conti et ales 1974; and Chanarin and Perry. 1967). The molar absorptivity was determined to be $3.18 \times 10^{-4}$ a-1 ca-1 (24a). The ultraviolet spectrun showed a maximum at 290 nm. and a mininum at $245 \mathrm{~nm}$. (Conti et ales 1974, and Chanarin and Perry. 1967). The infrared spectrun for the magnesiun salt has ben characterized by conti et aler (1974). and the proton magnetic resonance spectrun was reported by Blair and Sauders (1970).

2. METHE, Isolation and Identification Donaldson and Keresztesy (1959) reported the 
page 44

extraction fron horse liver of a "citrovorun factor precursor" which did not support the growth of either $\underline{S}_{2}$ faecalis or Ie citroororuge The precursor, named Prefolic A. was reportedly converted to citrovorua factor by two separate enzyne systeas, an PAD-Linked system and a transforaylase nechanisa (Donaldson and Reresztesy. 1959). These authors also showed that Prefolic a could be readily conrerted, via enzyatic oxidation, to IBPA and formaldehyde.

Iarrabee and Buchanan (1961) discorered an internediate of methionine biosynthesis which was identified as a folate conpound containing a one carbon substituent. The folate derivative did not support the growth of either $\underline{S}_{2}$ faecalis or Ienule citrovorum, but it was later deternined that it would support the growth of le casei. (Larrabbe et alee 1961). This compound was found to contain approxinately one nole of nethyl group per mole of compound. Larabee et ale (1961) used Prefolic A as the substrate in the conversion of rethionine to honocysteine (in the presence of DPH, PAD, Agt2, ATP and "B12 enzyne"). These authors proposed is nethyl THF as the tentative structure of the folate derivative (Larrabbe et ales 1961).

Prefolic a. as the bariun salt, was isolated in "essentially" pure fora fron horse liver by Donaldson and Keresztesy (1961) wo reported that its spectral characteristics were sinilar to those of dibyaro and tetrahydro folic acids. Reresztesy and Donaldson (1961) 
reported the chemical synthesis of Prefolic a from dl THP. The synthetic aterial was approximately as active as the natural Prefolic a relative to $\underline{\underline{c}}$ casegi activity. and it vas found to have the same ultraviolet absorption characteristics (Donaldson and Reresztesy. 1961). Blair and Saunders (1974) have since reported the preparation of (+,-)-HeThr fron folic acia, using sodiu borohydride as a reducing agent.

\section{Biochenical Role of teTHF}

The enzyae gr-eo methylene THF reductase, found in the liver of various rertebrates and in certain bacteria (Blakely. 1969). Catalyses the reduction of $\mathbb{1 5}^{\text {-2o }}$ wethylene THF to METHF. This reaction represents the major biosynthetic pathuay for uETHF. This reaction can use either NADA. NADPA, or PADE2 as the electron donor (Donaldson and Keresztesy 1962 ).

Dagner (1966) isolated an enzye. tentatirely named trinethylsulfoniun: tetrahydrofolate methyltransferase which catalyzes the methylation of ThP as shoun in Pigure 4. This, howerer, is not a najor mechanisa for the synthesis of METHF.

In adition to the identified enzym mediated mechanisms of uetrF biosynthesis, indirect evidence suggests a third pathway- Seru concentrations of HET are wuch higher following oral administration of folic acid or folinic acid (LE) than after identical doses 
page 46

administered parenterally (Nixon and Bertino, 1972, Mehta et ales 1978). This observation has led to speculation that significant synthesis of METHF occurs in the intestinal mucosa (Baker et alles 1965, and Chanarin and Perry. 1970) although the precise mechanisms responsible for the synthesis have not yet been elucidated.

Larabee et altee (1961) first identified gETHF as the folate intermediate in the interconversion of homocysteine to methionine. In the presence of appropriate enzymes and cofactors MTHP transmethylates vith homocysteine resulting in the synthesis of methionine and THF.

This transmethylation Iequires several cofactors: ATP. Mg+2, and either FADH2, MADH or FAD (Larrabbe et als=2 1961) as the electron donor. This appears to be the only syathetic pathway inrolving uETHP. 


\section{POLATE ASSAYS}

\section{A. Microbiologic}

Interest in the quantification of serua folate concentrations was initially focused on determining the etiology of various anenias (Kamen and Caston, 1974), by nicrobiologic methods. Sauberlich and Bauman (1948)

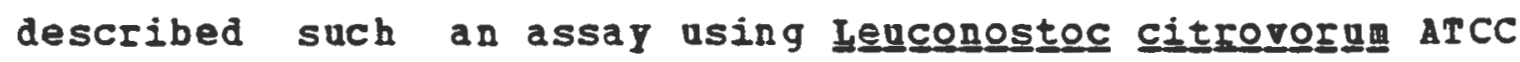
8081. later identified as Pediococcus cerevisiae for which LEO is an essential grovth factor. The determination of LEO concentration (or activity) was carried out by measuring the zone of grouth around standard paper discs saturated uith leucovorin solutions. Lactolobacillus cassei ATCC 7469 and streptococcus faecalis 9 have been used in a similar manner (Grossowicz et alles 1962).

The microbiologic assays are not specific. Por example, Is casei ATCC 7469 responds not only to pteroyl glutanic acid but LEO and also certain polyglutanates (Grossowicz et alle 1962) - S= faeㅡ르로오 utilizes folic acid and several tetrabydrofolic acid derivatives as does $P_{2}$ cererisae. In addition to their lack of specificity. microbiologic assays are generally tine consuning. often requiring eighteen to twenty-four hours of incubation time and. nore importantly. may be affected by antinicrobial and antineoplastic agents in the blood (Kamen and Caston. 1974) - However, Hutchinson and Burchenal (1952) isolated a methotrexate resistant strain of Le citrororum ATCC 8051 
page 48

and lehta and Hutchinson (1975) reported the use of this strain for the determination of LEU in the presence of methotrexate. The eventual isolation of a nethotrerate-resistant strains of $\underline{L}_{-}$caseis and $\underline{s}_{-}$faega made possible the determination of aBTHF as well (behta and Hutchinson, 1977) . L $\quad$ casei responds to all forms of folate. from which total folate activity can be neasured. while $S_{n}$ faecalis var. Durans responds to all forms of folate except aETHF (Mehta and Hutchinson, 1977)... Thereby. the difference in activities between the two microbiologic assays is attributable to serum levels of uETHF. These methods, although useful, remain subject \pm 0 interference by antinicrobial agents and other antineoplastic agents which may be used in conbination chenotherapy.

\section{B. Spectrophotonetric Methods}

1. Oltraviolet

The extinction coefficient (282 $\mathrm{nm}-$ ) for leo has been reported as 2.39 to $2.41 \times 10 \mathrm{H}^{-1} \mathrm{~cm}^{-1}$ in $0.1 \mathrm{~N} \mathrm{NaOH}$ (Zakrzewski and Sanson, 1971)- Oltraviolet spectroscopy. hoverer, has not been employed for LEU analysis for two reasons: (1) the nolar absorptivity reported is not considered to be reliable because of frequent impurities in samples: and (2) LEO readily dehydrates under acidic conaitions to Ns, No nethengl THP. which absorbs at 352 nin.. thus affecting the accuracy of leucororin analysis 
(ponte et ales 1979).

Pont et allee (1979) state that IEO nay be analyzed by acidification with $0.1 \mathrm{~N}$ BCl followed after 1.5 to 2.0 hours by OV neasurement, provided that no interfering species are present. Interfering species are considerod to be folate derivatives which wight convert to anhydoleucororin upon acidification. Because such folates are thought to exist in blood (Blakely, 1969) OV spectroscopy is not considered applicable to the analysis of LEU in biologic fluids.

\section{Pluorometric}

LEO exhibits naximu natural fluorescence at pH 7.0 with excitation and enission at 370 na and 460 nn (Dngan et aler 1957) and 314 na and 365 nm (Jyeda and Rabinowitz. 1963) Iespectively. The differences in warelengths reported were attributed to sanple inpurities, pH variations, and quenching (Pcnte et ales 1979). Although LEO will fluoresce and quantitative results are similar to those obtained by microbiologic methods (Ponte et alle 1979). fluorometric methods have not been applied to the deternination of LEO.

\section{Other}

several radiochemical techniques for seru folate analysis have been reported recently (Kanen and caston, 1974: Rothenberg et alfee 1979; and Raso, 1977). All of 
page 50

these nethods rely on the competition between METHF and tritiated pteroylglutanic acid (3B PGA). For the binding sites on naturally occuring protein. (METHP is used as the reference folate because it is the major circulating seran folate.) The protein source may vary but nilk protein is the nost compon binder in use (Rothenberg et alles 1979). In these nethods, tritiated $3 \mathrm{H}$ PGA is displaced from the binding site by uETHF, and standard curves are prepared by plotting percent 3 H PGA bound as a function of MeTHF concentration. The higher the HeTHF concentration, the less 3 H PG bound.

These techniques, howerer, cannot be applied to leu because the affinity of the binding protein for the formyl tetrahydrofolate (LEU) is not strong enough to displace ${ }^{3} \mathrm{H}$ PGA (Rothenberg, et alee 1979). Further, since sone circulating folate is present in the bound form these wethods do not reflect total folate activity but rather are an indication of actirity relative to uETHP standard (Kamen and Caston. 1974). Pinally, the effect of other agents notably antinicrobials and antineoplastic agents (e.g.. methotrexatel on these methods has not been reported. Bothenberg et al $=1$ (1979) dereloped an indirect approach in order to measure IEO using the radiochenical technique. METBF is first measured in a portion of serun or urine sample using standard radiochemical technigues. mother portion of the same serum or urine sample is then acidified and exposed to sodin borohydride wich converts 
page 51

LEO (formylFH4) to methylPB4. The difference in UETHF concentrations between the treated and untreated samples is assumed to be due to the original concentration of IEO.

Langone and Levine (1979) have published a preliminary report of a radioinunologic assay for lencovorin using an anti-leucororin antibody produced in rabbits. The nethod is reported to be sensitive to 0.10 nanograns of LEO added to sernn. Other forms of folates and methotrexate reportedy do not interfere with the determination of LEO: howerer, due to the antibody's specificity, the method is not applicable to the predominant circulating folate. GETBP.

Anion exchange chrowatography was the first HPLC application for the separation of mono-pteroylglutamates (Stout et alee 1976 including LEO and uetrif (Reed and Archer 1976). However, these methods are relatively inefficient; in addition they require long chromatographic colunns ( 4 1/2 ft.) and unacceptably long chronatographic run times. other HPLC methods have recently been reported (Reif et alles 1977. and Chapman et ales 1978) and a complete revier of chronatographic anethods applicable to various pteridine and/or pteroylglutamates has been published (uontgonery et ales 1975).

The use of apL coupled with electrochenical detection has been recently reported for the deteraination of aTHF in plasma and spinal fluid (Lankelma and Van der Kleijn. 19801. A detection linit of $2 \times 10^{-9 M}$ METHF and $100 \%$ 
page 52

recovery fron body fluids is claimed. The low linit of detection is attributable to on-column concentration of the folate. Sample treatment requires the use of ten percent trichloroacetic acid in $0.1 \mathrm{~N}$ HCl to precipitate plasma protein prior to centrifugation and sample injection. Because of "early plasma peaks in the chromatogram" and "foreign eluent". It was necessary to "rent" the column to prevent "poisoning" of the electrode surface (Lankelma and Van der Kleijn. 1980). The method is not applicable to IEO wich is not detected under the chromatographic and electrochenical conditions emplored. The use of trichloroacetic acid in $0.1 \mathrm{~N}$ HCl raises considerable doubt regarding the integrity of the various forms of reducad folate in the sanples so treated. For example, when LEU is acidified it loses water to become ps.N10 methenylFH4 (1969). Other reduced folates are subject to rapid hydrolysis as vell (Blakely 1969). The possibility exists that all folate present in plasma samples treated by this aethod are converted to some intermediate form of reduced folate or to uETHF. If this vere indeed the case the reported sensitivity would be erroneous since the total peak height or peak area yould not be due solely to METHF. In addition to the methods applicable to the assay of LEO and/Or for METHF in biologic fluids, sereral technigues have been reported for the separation and identification of folate derivatives. These methods are not sufficiently sensitive to the analysis of folates in biologic fluids. 
page 53

8rown. Davidson, and scott (1973) reported the separation of pteroylglutamates and related compounds by thin layer chromatography. This and other methods have been thoroughly reviewed by Blakely (1960).

\section{ELECTROCHEUICAL DETECTION}

A severe linitation to the application of high pressure liquid chromatography (HPLC) to the analysis of drugs in biological fluids has been the lack of a suitable detector (Riggin et als 1975). Five basic reguirenents of an BPLC detector have been Iecently enumerated by hashimoto and Marupama (1978): (1) high sensitivity and reproducibility: (2) versatility; (3) continous monitoring of column effluent: (4) independence from operating parameters such as flow rate and mobile phase composition: and (5) a vide linear response. Also important is the ease of operation as vell as the durability and stability of the system. The spectrophotonetric methods, i.e.. ultraviolet, visible and fluorometric, although suitable in any respects, are not applicable for componds without chromophores. those with low molar absorptivity. or those that do not fluoresce. Refractive index, although versatile, is not particularly sensitive and is therefore not generally applicable for the analysis of arugs in biological fluids.

The possibility of using electrochemical techniques to 
page 54

monitor HPLC effluents was first discussed by kenula (1952). although the technology arailable at that time severely restricted the application of this method. Kissinger et_alae (1973). Takata and Huto (1973) and Fleet and Little (1975), have recently described electrochemical detectors compatible with modern HPLC technology. Since these reports appeared electrochenical techniques have been applied widely to the quantification of drug substances in biological fluids (Greenberg and Mayer, 1979: White, 1979: and Iunson et alse 1978). Although the electrochemical detector is not the videly sought "universal" detector for HPLC, it provides a selective and sensitive method of detection for suitable conpounds.

\section{A. Theory}

The coupling of electrochemical detection to high pressure liquid chromatography relies on introducing the colunn effluent to a region, or cell, in which electrolysis can occur (Takata and Moto, 1973). Electrochemical detectors in current use are based on nDC hydrodynamic chronoamperometry" in which "current is measured as a function of tine with a constant potential applied at a fixed electrode exposed to a woring fluid" (Shoup, 1979). This may best be conceived as electrolysis at a fixed point along a flowing strean. Electrolysis can result in either oxidation or reduction reactions. since reduction of dissolved oxygen, wetal ions, and hydrogen can hinder 
page 55

electrochemical detection, most practical applications have been carried out in the oxidation mode (Shoup, 1979).

Scheme I represents the simplified reaction which occurs when an organic conpound $R$ is oxidized to an intermediate compound o, Yielding n electrons (e). The unstable intermediate may be expected to form. irreversibly. the stable product $P$.

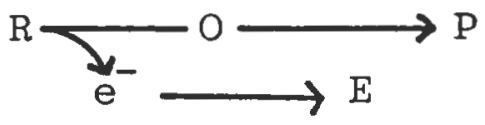

(Scheme 1)

This is a simplified view and generally the electrochemistry of organic nolecules of clinical significance is not vell understood (Rissinger et aIㄹㄹ 1979).

The quantity of electricity required for this reaction can be calculated according to Faraday's Law Equation 3.

$$
\mathrm{Q}=\mathrm{n} * \mathrm{~F} * \mathrm{~N}
$$

There;

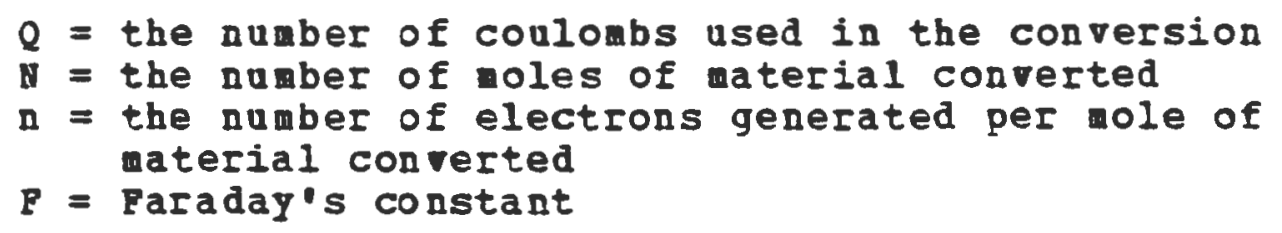

current is a measure of the rate at which the oridation proceeds and is described by Equation 4. 
$i=d Q / d t$ and $n F *(d N / d t)$

(Equation 4)

Where $i$ represents current and all other terms are as described earlier.

The efficiency with which material is oxidized (or reduced and current is produced, can be calculated fron the number of moles of aterial that react (N) and the total numer of eoles entering the electrode region (Ntotal). according to Equation 5.

$$
\text { Efficiency }(\text { Eff })=\left(N * N_{\text {total }}\right) \times 100
$$

(Equation 5)

Anperonetric detectors typically operate with efficiencies ranging from four to ten percent (Kissinger, 1977). The current produced via electrochemical reactions and bence the efficiency of the systen is affected by sereral parameters, sone of which are gorerced by the electrochemical process and others of which way be controlled experimentally. Equation 6 relates these paraneters to the liniting current (i lim) (nillard et al=e 1974).

$$
i_{\lim }=\left(n F A D C_{b u l k}\right) / \varepsilon
$$




\section{Where:}

$\mathrm{n}=$ number of moles of material converted electrochenicaly

$F=$ Faraday's constant

$A=$ surface area of the electrode

$D$ = diffusion coefficient of the electroactive species in the solvent or mobile phase.

cbalk = the concentration of the electroactive species in the bulk or abile phase.

(s) = the diffusion layer thickness.

Faraday's constant and $D$ are properties of the electroactive species and cannot be controlled experimentally. The diffusion layer thickness and electrode surface area are variables which can be used to influence the current generated frow the electrolysis of a sample. Diffusion layer thickness. (s). refers to the distance through which the electroactive species nust travel from the solution (or nobile phase) to reach the electrode surface. For an electrocheaical reaction to occur, the electroactire species nust: (1) diffuse fron the balk solution to the electrode surface; and then (2) transfer electrons at the surface (Kissinger, 1977, and Dillard et alse 1974). The rate-deternining step is considered to be diffusion through the bulk solution. Which is governed by Fick's First Law (Rillard et al=e 1974). Equation 7.

$$
J=D *\left(G_{b u l k}-E\right)
$$


page 58

Where

$J=f l u x$

$D=$ diffusion coefficient

Cbulk = concentration of solute in the bulk phase

Co = concentration in the electrode surface

(s) = diffusion layer thickness

It is apparent from Equations 6 and 7 that flux is inversely proportional to the distance electroactive species ust travel and by decreasing (s). the current generated can be increased. Experimentally. (s) can be regulated in two ways: first, by confining the sample within a thin film of electrolyte passing orer the electrode surface, an application of the principle of lov rolume flow thru cells (Figure 51: secondly, by varying the flow rate of solution through the thin layer cell to effect an increase or decrease in the value of (s). Increasing flow conpresses (s). resulting in a smaller diffusion distance, thereby increasing $d N$ dt-n and the current generated (Kissinger, 1977; and Buchta and Papa, 1976). In practice, hoverer, high effluent flov rates decrease the residence time of electrons within the electrochemical cell and may actually decrease the current generated by an electroactire species.

The rate at which waterial reaches the electrode surface is not only a function of flux. J, but of the electrode surface area A, (Millard et ales 1974). according to Equation 8 .

$$
\mathrm{dN} / \mathrm{dt}=\mathrm{A} * \mathrm{~J}
$$


Increasing the surface area of a electrode will result in a faster rate of electron production and, according to Equation 8. will generate a larger current. However, the conversion of material in the mobile phase, i.e.. electrolytes, trace metals, etc. will also increase. This increase in background current may negate the adrantages of using electrodes vith large surface areas.

Current ay be influenced by another neans, not apparent frow Equation 6. Equation 9 describes the relationship between the potential applied to the electrode surface and the resulting current:

$$
e=e^{\frac{1}{2}}+\frac{r t}{n F} * \ln \left(\frac{i}{I_{1 i m}}\right)
$$

(Equation 9)

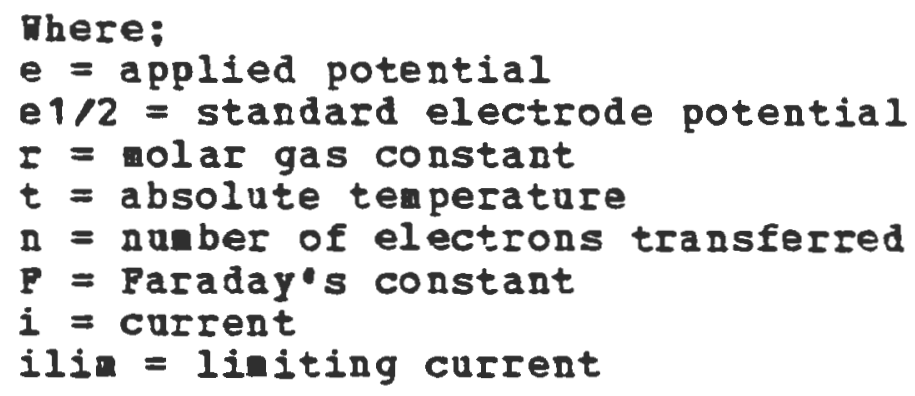

a current-voltage curve, (byarodynanc roltamogran) can be produced by plotting current as a function of applied potential. The selectivity of electrochenical detection is based on the difference in behariour between electroactive species and the currents produced at various potentials. "For example, methoxyhydoxy compounds are 
page 60

more difficult to oridize than are catechols and therefore can be 'tuned out" of a chromatogram by lowering the applied potential" (Kissinger, 1977).

\section{B. Electrode Material}

A uide range of electrode naterials have been applied to electrochemical detectors. Iiquid chromatography electrochenical detectors hare been prepared fron carbon paste (Atuma and Iindquist. 1973). mercury (Fleete and Little, 1974). platinua (Hacbonald and Duke, 1973). pyrolytic carbon (10ightman et all=e 1978). glassy carbon (Birminghal et altee 1979). silver (Takata and Huto, 1973). and graphite inpregnated silicone rubber (zaradi et alles 1974). Mercury is most often used for reduction reactions uhile carbon paste and glassy carbon electrodes have been the dost widely used for oridation procedures (shoup. 1979). Because the reported detection limits for oxidizable substances are considerably lover than for reducible conpounds, the various forms of carbon and carbon paste have received the most attention (Mightman et ale 19781 .

The choice of electrode material may be governed by sereral considerations. Mobile phase composition is an important factor; for example, carbon electrodes with oil bases are adrersely (in terms of surface distortion) affected to a greater degree by high concentrations of organic in a mobile phase than are either carbon 
page 61

impregnanted wax or glassy carbon. Many organic compounds react at significantly different rates depending on the electrode used. The greatest sensitivity can be achiered by finding the electrode producing the fastest rate of electron transfer for a given conpound (Kissinger. 1977).

Further, the electrode naterial is prone to

auto-oridation (OI Ieduction) which will contribute to residual (background) current. The extent to which residual currents can be tolerated will also play a role in the selection of the proper electrode.

A11 carbon paste electrodes suffer from three basic problens: (1) non-reproducibility of electrode surface: (2) adsorption of material from mobile phase; and (3) surface oride formation (Fleet and Little. 1975). The degree to which electrode surfaces are "poisoned" by the latter tro factors, and the ease with which surfaces can be regenerated are paramount in determining the usefulness of an electrode aterial (Fleet and Little, 1975). A significant disadrantage in the use of electroanalytical techniques is the fact that electrochemical details at any electrode surface are poorly understood, as are the differences between types of carbon electrodes (Kissinger. 1974).

c. Cell Geonetry and operation

Several designs for thin layer. lov roluee. electrochenical cells have been described (Buchta and Pappa, 1976; Bashinot and Maruyana, 1975: and Riggin et 
page 62

ales 1975). Virtually all designs use a three electrode configuration (figure 2). The critical parameter in electroanalytical techniques, as discussed by Kissinger (Kissinger. 1977), is accurate control of the potential difference between the electrode and mobile phase (bulk solution). In the nornal operating mode the rorking electrode (u) is set to the desired oxidation potential. The reference electrode nonitors the roltage inpressed between the working and reference electrode. No current passes through this electrode. it simply weasures potential. As the potential at the vorking electrode drifts, an electronic feedback mechanism adjusts the potential of the auxillary electrode to conpensate and return the potential difference between the working electrode and bulk solution to its operator deterained ralue (Kissinger. 1979 ).

In operation. the carrier electrolyte in the nobile phase will produce a current. This current will increase as the concentration of solute (sample) rises vithin the electrochenical region. The resistance within the electrocheaical cell will drop, and, is compensated for by a decrease in the potential of the auxiliary electrode. This action will result in a constant applied potential at the surface of the working electrode. The change in current produced by the solute (sanple) passing through the cell is proportional to concentration as previously described. 


\section{CHROAATOGRAPHY}

"The object of any chromatographic experiment is to separate the components of a mixture by placing a snall sample of ixture onto the head of a colun of a finely divided partitioning naterial and subsequently washing or eluting the mixture through the colum by passage of a suitable eluent... One hopes that the different components of the mixture will then migrate along the column at different rates and so form discrete bands which disengage as they aigraten (Knox 1977).

Since 1976 an estimated $60 \%$ to $70 \%$ of the analytical work preforned bY High Pressure Liquid Chromatography (HPLC) has been carried out by "reverse-phase

chromatography" (Horvath and delander, 1977). The tern "reversed-phase" was coined by Howard and Martin (1950) to distinguish chromatographic systems employing a non-polar stationary phase and a polar mobile phase. from the conventional system of using a polar stationary phase and a less polar nobile or eluent phase (Borvath and Melander. 1977).

In reverse-phase chromatographic systems 5 and 10 um diameter "hydrocarbonaceous bonded" stationary phase particles having octadecyl or octyl functions bound via siloxane bridges to the silica surfaces are the nost common (Horvath and Helander, 1978). A vide variety of elution phases such as aqueous buffers, hydro-organic mixtures or 
page 64

non-aqueous organic solvents may be used, giring the method considerable flexibility. In addition, the use of complexing agents and pH changes can be used to advantage in manipulating retention values.

Reverse-phase chromatography is a forn of liquid-liquid chromatography in which the mobile phase is in contact with the stationary phase over a large surface area. Onder those conditions, equilibrium distributions of the solute between the two phases occurs rapidly. Mon-polar compounds are retained by the stationary phase to a greater degree than are ionic material. Thus, compounds elute fron reverse-phase colums in order of decreasing polarity.

The development of ion-pair chromatography has been attributed to schill and co-workers (Gloor and Johnson. 1977). In this technique ionic or ionizable conpounds can be paired with a counter-ion of the opposite charge to form a reversible ion-pair complex. The complex then behaves as an electrically neutral and non-polar conpound, which results in the complex having an increased retention in reversed-phase systems. By varying the size or charge of the counter-ion the degree of retention and hence resolution. of a compound can be controlled.

Two mechanisms for the retention of the ion-pair conplex have been proposed. the first postulates that the ion-pair complex partitions directly in the stationary phase. The second postulates that the counter-ion 
page 65

partitions into the stationary phase with the ionic group oriented at the surface, and in this configuration may act as an ion exchange column (Gloor and Johnson 1977). These authors, in a review of practical aspects of reverse-phase ion-pair chromatography, suggest that the actual aechanis is nore complex and involves both postulated mechanisms as vell as adsorption, micelle formation, and complexation of both the solute and ion-pair reagent. Johnson and Gloor (1977) have published an excellent review of the practical aspects of ion-pair chromatography.

Because nost drug substances are weak organic acids or bases, they may be expected to possess some charge, dependent apon pH. Paired-ion chromatography has provided a nechanis wherein the adrantages of reverse-phase chronatography: flexibility: selectivity; resolution: and economy can be applied to the analysis of drug substances. The ability to systematically control the separation of ionic compounds of widely different types is perhaps. reversed-phase paired-ion chromatography's most inportant asset. The application of this technique in drug research, both in quality control and in therapeutic ding nonitoring. has been the subject of recent revieus (Johansson et alle

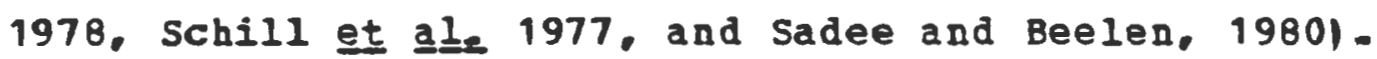


page 66

VI PROTEIN BINDING

A. Description of Protein Binding Interactions Protein-drug binding results from an intramolecular interaction between a biological macromolecule and a relatively small drug molecule (Klotz, 1973). The binding of drugs to plasma proteins assumes considerable interest since it is generally accepted that only the free or unbound drug can diffuse across cell membrases, reach receptor sites and exert a pharmacological effect (Ritchell. 1975). Moreover, the extent of protein binding can profoundy affect the distribution and elinination characteristics of a drug (Gillete, 1973 and Dafton. Israili, and perel, 1973). Competitive displacenent fron a binding site. by dIugs or plasma components, way be an important factor for a drug with a high degree of binding (Magner, 1975) - BY increasing the concentration of free drug in plasma. displacement may result in an increase in therapeutic response and lead to drug toxicity. such is the case, for eramle, with phenytoin, (Horselli, 1970). dicumarol (Sellers and Koch-geser. 1970) and ury (Dixon. 1965). In addition, such alteration in protein binding may affect the rate of elimination. (Gillete. 1973 and Iery and Yacobi. 1974) and alter a drug's rolume of distribution. The major plasaa and tissue protein responsible for the non-specific binding of most drug substances in albumin (Dayton, et alle 1973 and Chignel. 1971). Other plasna 
page 67

constituents, ege the lipoproteins and globulins, may also bind drugs: howerer. since these components are present in much lover concentrations in plasma than in albumin, their contribution to the protein binding of drugs is considered to be of secondary importance (spector et al=e 1973 and perkins et alee 1969).

Albuin is composed exclusirely of anino acid residues: eighteen anino acids have been identified (Hughes, 1954). The molecular veight of albumin has been reported at between 65,000 and 69,000 daltons (Borga et alles 1969)- The concentration of albunin in humans is generally accepted to be 5.9510-4M. although various disease states can greatly alter the albumin concentration (Dayton et ales 1973). The structure of the protein has been described as an "elongated ellipsoid" with a length and diameter of approximately 150 and 38 Angstrons. respectively (Bughes, 1954). Albumin is a bighly charged nolecule having about 100 ionizable carboxyl groups and a nearly equal number of groups wich are positively charged at the isoelectric point (pH 5.0) (Tanford et alse 1955 and Borga et ale 1969). At physiological pH of 7.4 albumin possesses a net $(-19)$ negative charge. Positirely charged drugs vill be strongly attracted to the negative sites on the nolecule with the formation of strong ionic bonds. Since the nacronolecule has a net negative charge. negatively charged drugs are repelled to some extent: hoverer, binding of negatively charged drugs to positively 
page 68

charged sites can occur (Settle et alee 1971). In addition to ionic bonds, drug-protein complexes can be forned through ran der Maal's forces, hydrophobic bonds and hydrogen bonding (Chignell, 1971 and Ritchell, 1975). Basic drugs, positively charged at physiological pH, are loosely bound, occupy a large numer of binding sites and are easily displaced. Acidic drugs, negatively charged. are strongly bound to albuain and generally occupy only one or two sites. Displacement of acidic drugs is of a more specific nature than that for basic compounds (piafsky and Borga, 1977 and Borga et al=e 1969). Since acidic conpounds bind only to a limited number of sites. displacement occurs only if a second drug has an affinity for the same binding site (Schrartz, 1979). The basic groups from the anino acid residues of arginine, histidine. and Iysine and the acidic groups of aspartic acid. glutanic acid and tyrosine are responsible for the binding of acidic and basic drugs respectively (Ritchell, 1975).

B. Equations Describing Protein Binding Protein binding can be described in terms of the fraction of drag present which is bound to plasna protein. since, in most cases, the concentration of free drug i.e.. the non-protein bound portion (as opposed to bound drag) is determined analytically, the expression regarding the percent of drug bound is frequently written as follows: 
page 69

Percent Bound $=\left[D_{t}-D_{f}\right] /\left[D_{t}\right] * 100 \%$

(Equation 10)

where Dt and Df represent the total and free ding concentrations respectively.

The degree to which drugs bind to proteins is frequently a function of the total drug concentration present. As the total concentration increases, saturating the available binding sites, the percent of drug bound decreases (Curry. 1970, and Kunin. 1967). Protein concentration also affects binding. lor plasua protein lerels. such as those in hypoalbuminemia, can Ieduce the number of available binding sites and result in increased free drug concentration (Dayton et ales 1973 and Lund et ale2 1971). Conversely, if the concentration of either albumin or other protein is elevated, an increase in the number of binding sites may result in lower concentrations of free drug (Benhold. 1966). When reporting the extent of drug binding, it is important that the total drug concentration and the albuein (or other binding protein) concentration be described.

Protein binding can also be characterized by using affinity constants and numbers of binding sites to which a drug is bound (Scatchard. 1949). The basic assunption of this nethod is that all sites of a given class are independent of each other and binding of one colecule does not effect the binding of any other drug nolecule.

Drug-protein binding equilibriun is generally 
page 70

considered to be an instantaneous, reversible process (Heyer and Gutman, 1968). The reaction between drug and protein can be expressed as follous:

$$
[D][P] \rightleftharpoons[D P]
$$

(Equation 11)

Where $D$ and $P$ represent the molar concentrations of free drug and protein respectively. DP is the molar concentration of the drug-protein complex, and ka, ka are the association and dissociation rate constants respectively (scatchard, 1949).

The association constant, Ka, can be written as:

$$
\mathrm{Ka}=[\mathrm{PD}] /[\mathrm{P}][\mathrm{D}]
$$

(Equation 12)

The degree of binding. I, can be expressed as the noles of drug bound per mole of protein:

$$
r=[P D] /[P D]+[P]
$$

(Equation 13)

Which can also be defined as:

$$
r=\mathrm{Ka}[\mathrm{D}] /(1+\mathrm{Ka}[\mathrm{D}])
$$

(Equation 14)

If the protein is determined to have $n$ independent and equivalent binding sites, the quantity I can be written as follows: 


$$
r=\mathrm{nKa}[\mathrm{D}] /(1+\mathrm{Ka}[\mathrm{D}])
$$

(Equation 15)

If more than 1 group of equivalent binding sites are present. Equation 13 can be expressed in a more general form:

$$
r=\mathrm{n}_{i} * \mathrm{Ka}_{i}[\mathrm{D}] /\left(1+\mathrm{Ka}_{i}[\mathrm{D}]\right)
$$

(Equation 16)

Where ni represents the number of binding sites of class $i$ and $\mathrm{KaI}$ is the association constant for class i.

Numerical values for n's (number of binding sites) and Ka's (affinity constants) can be calculated either by graphical techniques or by computer analysis. The scatchard method (Scatchard, 1949) in which (D) as a function of $r$ is plotted is the most common method by which protein binding data is presented. The scatchard equation in this forn is written as follows:

$$
r / a=\mathrm{Ka} * \mathrm{~N}-\mathrm{r} * \mathrm{Ka}
$$

(Equation 17)

When only one type of binding site is present, this plot will yield a straight line with a slope of -ka and with $X$ and $I$ intercepts equal to $n$ and $n K a$ respectively. If altiple binding sites are present a plot of this type will become non-linear and is best analyzed by non-linear 
page 72

iterative techniques. In addition to the scatchard method. Klotz (1946) and scott (1956) have presented transformations of Equation 8 that are linear for single site binding systems but become non-linear in the case of nultiple binding sites. Although either of these methods wil provide protein binding paraneters they are not as popular as the scatchard nethod.

Several methods describing the computer analysis of protein binding in the case of autiple binding sites hare been reported (Hetzler et a Fletcher and Ashbrook, 1973). Each of these methods uses iterative techniques for obtaining estimates of affinity constants and nuabers of binding sites.

c. Dethods of studing Protein Binding

Mang nethods are available for the study of drug binding to proteins. These methods depend on determining the concentration of free drug or detecting a change in a physicochemical property of the bound drug or binding protein aue to the arug-protein interaction (Klotz, 1973). Techniques for studying binding can be broadly classified as either spectrophotometric or non-spectrophotonetric (Chignell, 1971). The spectrophotonetric methods include optical spectroscopy. optical rotatory dispersion, circular dichroisn, and fluoresence. (Klotz, 1973). Electron spin resonance, nuclear magnetic resonance and $x$-ray crystallography. although not strictI spectrophotometric 
page 73

methods, mal be included in this broad classification. adrantages of these nethods include the sensitivity attainable and their non-destructive nature.

The non-spectrophotonetric methods rely on deternining the concentration of unbound drug following the distribution of free and bound forms between two phases (Klotz. 1973). Equilibriu dialysis is the wost comonly used non-spectrophotometric technique. oltrafiltration. altracentrifugation, diafiltration, and gel filtration are also included in this category.

oltrafiltration. like equilibrium dialysis and gel filtration. Ielies on the physical separation of unbound and protein bound drug. (Bush and Alvin, 1973). This separation is accomplished by the use of a neabrane which allows unbound drug to pass but retains macronolecules including the drug-protein conplex. The menbrane used for ultrafiltration usually consists of a microporous cellulose base coated with a continuous polymer film (Chignell. 19771 .

In altrafiltration, a saple containing both drug and protein is placed in a reservoir on one side of a membrane. Onlike dialysis in wich the driving force governing the separation is siaple diffusion, ultrafiltration relies on nitrogen gas pressure as the driving force for free drug to cross the membrane. The concentration of drag in the filtered aliquot (Df) and in the sanple solution (Dt). are measured and the percent drug bound is calculated according 
page 74

to Equation 1. This process may be repeated to determine binding over a wide range of total drug concentration.

The advantages of ultrafiltration include the speed in which analysis can be achiered and the small sample rolume (usually 2-3 al, which is required.

\section{Polate Binding \\ 1. Polic Acid}

The binding of folates to human serua is complex. The extent of binding reported for folates ranges fron almost nothing to approxinatel 65 percent depending on the method used for study.

Metz (1968) reported the binding of folic acid to human serun to be "reak". Condit and Grob (1958) and Neal and Milliass (1965) reported that almost no folic acid was bound to plasma proteins when determined via elctrophoresis. Elsborg (1972), hoverer, has suggested that the electrophoretic process might disrupt the drug-protein conplex.

Measuring folic acid activity by Ie casei activity. following sephadex chrowatography. Markkanen et a $1=$ (1972). Markannen and Peltola (1971). and Markannen (1968) determined that approximately $30 \%$ to $40 \%$ of folic acid actirity is bound to plasma protein. Horeorer, binding was found to occur with alpha2-nacroglobulin, albumin, and transferrin.

Johns and sperti (1961). using equilibriun dialysis at 
page 75

370 C. calculated the binding of folic acid to human serum (determined using tritiug labelled pteroylglutamic acid) to be a constant $64 \%$ orer a concentration range of 5 to 3000 nicrograns/liter. Sinilar results $(70.3 \%)$ vere reported by Alter et ala (1971) using the sane technique.

Oltrafiltration of plasma samples containing tritiated folic acid demonstrated 55\% to 65\% (Neal et alles 1965) and $50 \%$ to $55 \pi$ (Elsborg, 1972) of total folic acid to be bound.

In addition. increased binding capacity for folates has been shown in patients with urewia. leukenia and folate deficiency states. Rheumatoid artbritis vas found to result in a decreased folate binding capacity (Alter. $1971)$.

The extent to which folates bind with plasma proteins has been reported, the nature of the binding i-e, weak and nonspecific or "tight" and of a specific nature has been only recently addressed. Zettner and Duley (1974) studying folate binding by incubating serun witb tritiated PGA. deterained the reaction to be a "reversible equilibrium" process. They suggested that the large differences reported in the binding of folate to human sera result from the folate binders being at varying degrees of saturation.

The specificity of the folate binding site is suggested by zettner and Duly (1974) through experiments in which tritiated PGA, uETHF, leucovorin, and wethotrerate (in descending order) vere found to be capable of lowering the binding of folic acid. Non-folate compounds, hoverer. 
e.g.. barbiturates, phenytoin, and salicylic acid did not effect PGA binding.

\section{2. МЕTHF}

The binding of $\mathrm{C}-14$ labelled $\mathrm{AETHF}$ to normal human sera has been reported by spector et alles (1975) seram binding was deternined by altrafiltration at $23^{\circ} \mathrm{C}$ with a head pressure of 5 psi Nitrogen. sixty to seventy percent of the drug was reported to be bound, and was constant over the concentration range tested. In addition. phenytoin. probenecid, and aspirin were found not to alter the binding of UETHF.

\section{IEU}

The protein binding of leucovorin has not been reported. 


\section{EXPERIGEMTAL}

I. Uaterials and Equipment

A. Drugs

Calciun Leucovorin. Lederle Laboratories, Pearl River. NY.

Methotrexate, Lederle Laboratories, Pearl River, H.

dl-N-5-methyltetrahydrofolic acid. Bariun salt. Sigma Chenical Co.. St. Louis, no.

1-Ascorbic acid. Sigma Chemical Co.. St, Louis, MO.

Folic Acid, Sigma Chemical Co., St. Louis, HO. Gama-amino-butyric acid, Sigma Chemical Co.. St. Louis, no.

Dihgdrofolic Mcid, Signa Chemical Co.. St. Louis. Mo.

Tetrahydrofolic Acid, sigma Chenical Co.. St. Louis. MO.

Bethylene retrahydrofolic acid was obtained from the National Institutes of Bealth. Bethesda Md.

B. Reagents

Sorenson's Phosphate Buffer. pH 7.4. was prepared by airing together $1 / 15$ monopotassiun phosphate (576 m-) and $1 / 15$ disodiu phosphate (424 $\mathrm{ml}$-)

paired-ion reagents, 1-pentane, 1-heptane, and 1-octane sulfonic acid. Pic B5, B7, and PB respectively were obtained from Maters Associates. Hilford, MA.

C. Chenicals

Aneoniun Phosphate, dibasic, A.C.S, Fisher scientific Co.. Fairlawn. NJ. 
Methanol, ov Grade, Maters Assoc.. Inc.. Milford, MA.

Acetonitrile, OV Grade, Naters Assoc., Inc., uilford. IA.

Disodium ethylenediamine tetraacetate, A.C.S.. allied Chenical. Specialty Chenicals Division. Horristown, NJ.

Phosphoric Acid, 85, A.C.S, Pisher Scientific Co.. Pairlaun, NJ.

Potassiun Aydroxide, A.C.S.. Fisher scientific Co.. Pairlaun. NJ.

Sodiun Phosphate, Dibasic, A.C.S.. Fisher Scientific Co.. Pairlaun. NJ.

Potassiun Phosphate, Monobasic, A.C.S, Fisher Scientific Co.. Pairlaun, NJ.

Tetrabutylamoniun Chloride, Eastman Rodak Co.. Rochester, NT.

Oxalic Acid, A.C.S, Fisher Scientific Co.. Fairlawn. NJ.

Glacial Acetic Acid, A.C.S. Fisher scientific Co.. Fairlawn. MJ.

Mitric Acid, A. C. S, Fisher scientific Co.. Fairlawn. NJ.

Crystalline Human Serun Albunin. Calbiochem. Inc.. San Diego. CA.

Crystalline Bovine Serun Albumin. Calbiochem. Inc..

San Diego, CA.

Spectroscopic powder. grade SP 2, Onion Carbide Corporation. New York, MY.

Ceresin Plakes, Matheson Chemical Company. Lyndhurst, NJ. 
D. Equipment

Oltrafiltration Apparatus, Hodel 8MC, Anicon Corp.. Lerington. HA.

oltrafiltration Membranes, 10,000 m cutoff. Pa-10. Anicon. Corp.. Lexington. MA.

Dialyzer Tubing. $2.5 \mathrm{~cm}$. wide, $1.6 \mathrm{~cm}$. diameter. Fisher Scientific Co.. Fairlawn. NJ.

High Pressure Iiquid Chromatographic Pomp, Hodel 4-6000A. Maters Assoc.. Inc.. Milford, MA.

uBondapak C18 Ieverse phase stainless steel colunn. Maters Assoc.. Inc.. Hilford, MA.

Radial Pak A Liquid Chromatographic Colunn, 5 m. I. D.. Maters Assoc.. Inc.. Milford, MA.

Radial Compression Module, Daters Assoc.. Inc. Bilford. Ma.

Sep-Pak, C-18 Cartridges, Maters Assoc.. Inc.. Milford. HA.

BPIC Loop Injector, Hodel 7120, Rheodyne, Inc.. Berkley. CA.

Constant Temperature Drying Oren. Thelco Hodel 15. Precision Scientific Co.. Chicago, IL.

Digital घultimeter, B and K Precision nodel 2800 . Dynascan. Corp.. Chicago. Il.

Active Noise Filter, Hodel Sc102, Foxboro Analytical Division, Morth Haven, CT.

Series-parallel RC Combination Box, Eico, model 1140. Electronic Instruments CO.. Long Island City. MY.

Electronic Controller lodel IC-2a, Bioanalytical systems Inc.. M. Lafayette. IN.

Plexiglass paste Cell, Model Tl-3, Bioanalytical systems Inc.. M. Lafayette. In.

Rel-F, Glassy Carbon Cell. Model T1-5A. Bioanalytical systems Inc., M. Lafayette, IN. Silver-silver chloride Reference Electrode, Hodel 
RC-1, Bioanalytical systers Inc., R. Lafayette, IN.

Sample Concentrator Hodel 190, Fisher Scientific Con, Fairlawn, NJ. 


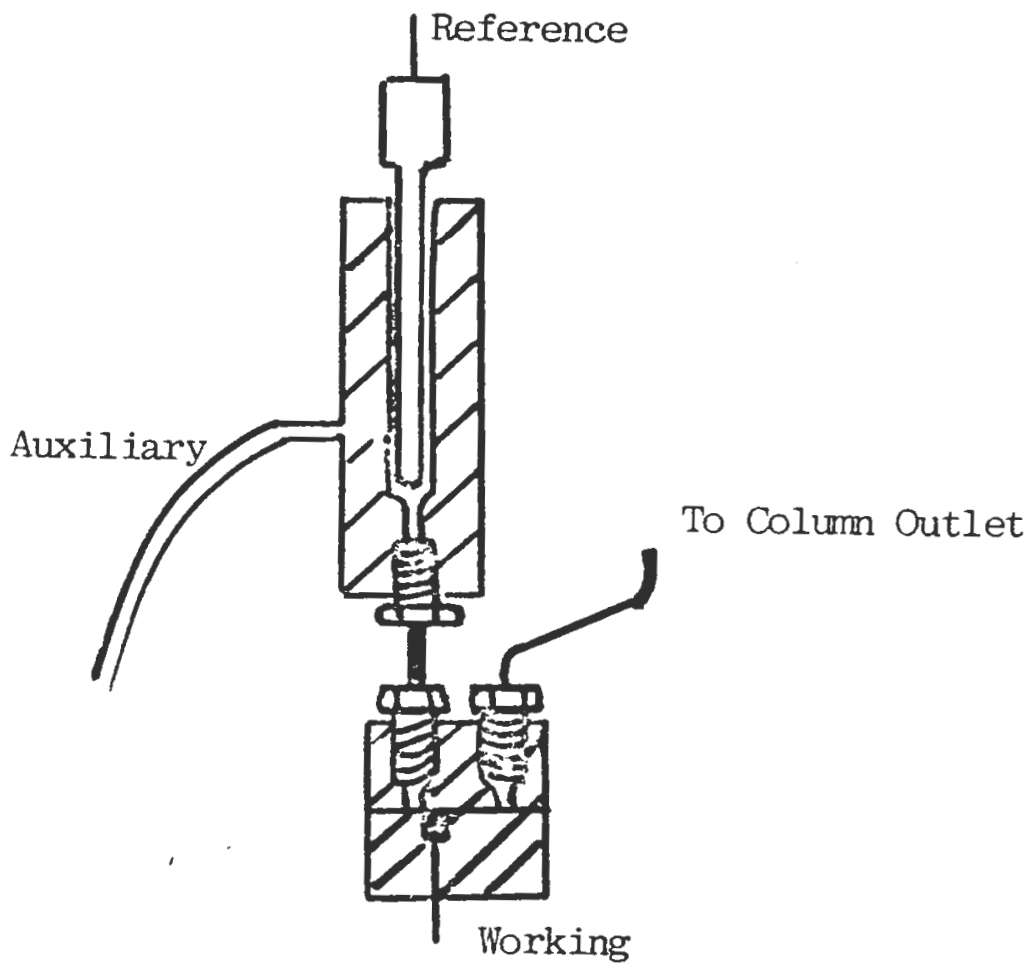

Figure 5: Diagram of the Electrochemical Flow-Through Cell 
page 83

and auxiliary electrodes vere downstrean from the vorking electrode in this arrangement. The completed unit was mounted inside an aluminum box $(20 \mathrm{~cm}$. $15 \mathrm{~cm}$. $11.5 \mathrm{~cm}$ ) which served as a support nechanisu for the cell.

\section{b. Electronic Connection}

The electrochemical cell was connected to the LC-2A controller in the following manner. The four leads extending from the controller unit were fitted vith banana plugs, one each for the working, reference, and auxiliary electrodes, and the fourth for ground. Four corresponding banana jacks yere installed on one side of the support box. One jack served as a ground, to each of the remaining three a short piece of insulated wire was soldered and connected to the individual electrodes using niniature alligator clips. Each lead was tested to insure continuity of current flow before use.

The IC-2A output jacks vere connected to an AMaLABS, Hodel SC 102 active noise filter, which served to reduce the residual current (background noise) inberent in the detector. The output from the noise filter vas coupled to the appropriate input terminal of the electronic integrator.

a 0.8 rolt potential was applied to the working electrode for routine quantification of LEO and HETHF. For nost applications the suming amplifier was set at 50 nanoanps/volt although in some cases the 20 nanoamp/rolt 
page 84

scale vas used. The active noise filter renained set at a constant gain of ten which boosted the input signal to the integrator approximately tenfold.

oxidation of the mobile phase components. i.e. supporting electrolyte, trace metals, and dissolved oxygen produced a background current ranging from 30 to 70 nanoamps/rolt.

\section{c. Blectrode Preparation \\ i. Carbon Paste Electrodes}

The wethod of preparing carbon paste electrodes was identical wether graphite/aineral oil, silicone oil, or wax-inpregnated graphite/011 pastes vere used. The working electrode block was carefully cleaned with water and nethanol. taking care to renore any old paste from the electrode vell. The cell was then dried carefully with Kinvipes and further allowed to air dry. A fev milligram saple of paste aterial uas placed on a folded computer card or piece of glassine paper. The paste was then poured into the three m. diameter electrode vell in several portions. A wooden applicator stick, two to three m. in dianeter. was used to tamp down the paste between aditions. This process was continued until the paste was approximately level with the cell surface. A small pile of paste was then placed on a clean computer card and the inverted electrode block pressed onto the pile. Using randon notion the block was noved around the card until a 
page 85

flat. smooth surface was obtained. The entire

electrochemical cell was then reassembled as described. Special care was giren to keep electrode paste awal froa other cell surfaces and to aroid scratching the cell surface.

After connecting all electrodes and the ground, the appropriate voltage was inpressed between the rorking and reference electrodes. The rate at which the cell surface was "conditioned". i.e., the time required for background current to decay to the 20 to 70 nanoamp/rolt range varied. In many cases one and one-half to three hours was required. in some instances the residual current did not decrease to acceptable levels after orernigit operation, in which case the electrode was repacked.

\section{ii. Glassy Carbon Electrode}

Regeneration of the highly polished surface of a glassy carbon electrode was accomplished in any one of several ways. After long periods of continuous operation. i.e.. six to eight reeks, a decline in detector sensitivity was often noted. Examination of the electrode surface shoved a dulling of the virror finish uhich has been attributed to the formation of oride filus and adsorption of products and reactants (Fleet and little, 1975). In nost cases sinply rinsing the cell surface with distilled vater. followed by nethanol was sufficient to restore the cell surface. 
page 86

In some cases the treataent detailed above did not restore the cell surface and polishing was required. The glassy carbon was first washed with distilled vater and left vet. A sall quantity, one to two ml. of jeveler's alumina paste was placed on a felt pad and retted slightly. The glassy carbon surface was then impressed upon the paste and the entire electrode block moved in a randon notion about the pad for approximately one minute. The carbon surface was then rinsed with distilled water and a drop of 6N Nitric Acid was placed on the carbon and alloved to stand for 30 minutes. The cell was then rinsed with water and methanol, allowed to air $d I Y$, and reassembled.

a potential was then applied to the vorking electrode for a mininu of four hours before quantitative determinations vere attempted; in most cases the detector required overnight operation to become "conditioned".

If polishing the carbon electrode with alumina did not regenerate the cell surface, an additional step was added to the polishing procedure. small amount of a diamond dust slurry was placed on a disc of "660 vet dry" abrasive. The cell surface was "rough" polished by this method before progressing to the alumina paste and subseguent steps as described above.

Once a potential was impressed between working and reference electrodes, the syste remained charged until the electrode surface required regeneration. 


\section{Chromatography \\ a. Aparatus}

The liquid chromatograph consisted of: a Raters Associates Model $6000 \mathrm{a}$ solvent delirery system; a Rheodyne hodel 7120 syringe loading sample injector equipped with a 100 al loop: either a Raters Assoc. UBONDAPAK C-18 reverse phase coluan (4ma $\mathrm{m} 30 \mathrm{~cm})$. Or an $8 \mathrm{ma}$ I. D. RADIAL-PAK C-18 cartridge (13mm $x$ 10cm) and RCH-100 Badial Compression Module: Thelco Model 15, constant temperature oven; and a BaS bodel IC-2A, electrochenical detector. The 1 rolt output of this detector was "stepped-down" and connected to a Maters Assoc.. "Data Module", electronic integrator.

\section{b. Solvent systems}

paired-ion chromatography was used for the separation and quantification of LEO and METHF in aqueous systems and fro serum. Two classes of pairing agents: pentane. heptane, or octane sulfonic acid, and dibasic amoniua phosphate (AH4) $2 \mathrm{HPO} 4$ vere evaluated for their suitability in the determination of reduced folates.

sulfonic acid buffers were prepared by pouring the contents of one vial of pre-mired paired-ion reagent. PIC 85. B7, B8 (Maters Assoc.) into a liter rolunetric flask which was then brought to volune vith distilled-deionized water, to pield a final paired-ion concentration of $5 \mathrm{mH}$. The pll of this buffer systen was aintained at 3.5 and was 
page 88

used without further nodification. The organic conponent of mobile phases which contained sulfonic acids ranged from $10 \%$ to $40 x$ methanol and $0 x$ to $10 \%$ acetonitrile. The final mobile phase was prepared by adding an appropriate volume of organic solvent (CH3OR or CH3CN) to a 1 liter volumetric flask which was then brought to volume with the previously prepared sulfonic acid reagent solution.

Dibasic amoniun phosphate, (BH4) 2HPO4, was also used as a "paired-ionn reagent. several concentrations of amoniug phosphate between 0.005 and 0.5 vere eraluated. An appropriate amount of reagent was placed in a volumetric flask and brought to rolume using distilled-deionized water. prepared as described above. The pH of ammonium phosphate nobile phases was raried between $\mathrm{p}$ H 3.5 and $\mathrm{pH}$ 7.0. and was adjusted after the nobile phase: buffer solution plus organic components, had been prepared. No corrections were ade for the different amounts of 13 PO 4 wich vere added to bring the mobile phase to the desired pH.

Sodiue EDTA has been reported to be valuable in quieting "electrochemical detector noise", (R. Shoop, 1978) presumably by chelating trace netals which may be found in the nobile phase conponents or in the chronatograph itself. Ten m Sodium EDTA was therefore added to each mobile phase as a "precautionary neasure".

All nobile phases were freshly prepared on the day they were to be evaluated. Following preparation each 
page 89

mobile phase was filtered through a lillipore Type-FH, 43m filter, which had been wetted with methanol. The mobile phase was stored in glass Erlenmeyer flasks and covered with Parafile during use.

\section{Protein Binding \\ a. Preparation of the uenbrane}

The ultrafiltration membrane vas soaked in distilled. deionized water for one hour to remove the glycerin coating the membrane. The membrane was then placed in the ultrafiltration apparatus, seren l. of water (one cell rolune) vas forced through the membrane, followed by an equal voluge of Sorenson's buffer, pH 7.4. The interior of the cell, menbrane surface, and teflon tubing through which the filtrate emerges were dried with a kinwipe before beginning a binding determination.

\section{b. Sample Preparation}

Euman serum albunin vas prepared as an eight percent (v/w) solution with Sorenson's buffer, pH 7.4, tventy four hours prior to a protein binding determination. The protein was wetted with buffer and gently agitated to aid dissolution. Foaming of the solution was aroided since this can result in surface denaturation of the protain. Pifty al. of the albuain solution was then poured into a 25 ca. section of dialysis meabrane which had been previously soaked in buffer solution and knotted at one end. The dialysis tube vas tied off and placed in a one liter flask 
page 90

filled with sorenson's buffer, $\mathrm{pH} 7.4$. tightly corered and stored at40c until used.

Borine serum albumin was prepared in sorenson's buffer, pH 7.4, as a four percent (w/w) concentration, the norual concentration of albuain in serum. The binding of leucovorin to bovine albumin was carried out using the ultrafiltration technique described previousl I. The range of total drug concentrations studied was from $2.5 \times 10^{-}$to

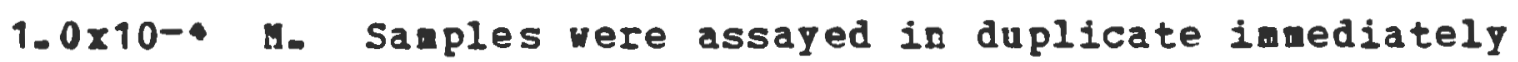
after ultrafiltration.

Lencovorin. 5-methyl THF and methotrexate solutions vere prepared daily using sorenson's buffer, pH 7.4. DIug stock solutions rere stored in tightly capped, opaque vials, to prevent light catalyzed oxidation and vere stored on ice during the binding experiment.

\section{c. Oltrafiltration}

Equal volumes (three and one-half ml. ) of arug and albumin solutions vere pipetted into the previously treated altrafiltration cell. The final albumin concentration produced in this manner was four percent (v/v). The drug-protein solution was stirred for approxinately 30 to 45 seconds before beginning the ultrafiltration and then throughout the entire filtration process. StirIing insures complete mixing of the drug and albunin solutions before beginning filtration and prevents nconcentration polarization". i.e.. accunulation of the retained protein 
at the menbrane surface creating a "boundary layer". The accumalated protein restricts the floy of solution through the nembrane, alters the filtration characteristics of the system and slows the rate of filtration (Anonyous. Amicon Product Literature, 19801 .

Nitrogen gas $(20$ psi) was applied to the cell, forcing the solution across the membrane. The first four drops of filtrate, approximately 200 microliters, vas discarded, the following 400 to 500 wicroliters was collected in a 12 × 75 ma. glass test tube, covered, protected from light and stored on ice until analyzed. All samples vere analyzed on the day the ultrafiltration was carried out. The ultrafiltration cell was washed with sorenson's buffer, $\mathrm{pH}$ 7.4. between each binding determination and a small quantity of buffer was forced through the membrane. The cell was then dried as previously described in preparation for the next analysis. Experiments were always carried out in order of increasing total drug concentration to minimize potential error due to drug carry-over from the previous saple. Each binding experiment ras carried out in triplicate. Samples vere assayed twice and the arerage value used to deternine the free drug concentration. In order to examine non-specific binding. i.e.. the binding of arug to material other than albuin. notably the ultrafiltration cell or membrane. seren m. aliquots of lencororin and 5-methyl THF, in Sorenson's buffer, pH 7.4. were pipetted into the cell and filtered as previously 
page 92

described. Quantitative analysis was performed on the pre and post filtered samples to detect any changes in drug concentration following filtration.

Three and one-half l. each of albumin solution and sorenson's buffer. $\mathrm{pH} 7.4$. (drug free) were pipetted into the ultrafiltration cell and filtered. The collected filtrate was analyzed to detect any components eluting from the albuain wich night interfere with the quantification of leucororin or 5-nethyl THF.

\section{Hunan Studies}

a. Buman subject Protection

A detailed report of the proposed project, its objectires. methods and potential hazards was submitted to Huan Studies Comittees and Institutional Reviey Boards at both the Oniversity of Rhode Island and Roger Rilliams General Hospital (Appendix I). Each subject who volunteered for the study was provided with a copy of the experimental protocol and was reguired to read and sign an inforned consent form which explained the study in detail (Appendix II)

\section{b. Subject selection}

six subjects meeting the criteria described in the experimental protocol vere selected for inclusion in the study. all subjects, three males and three females, vere healthy volunteers between the ages of 28 and 33 . The 
page 93

weighed between $45 \mathrm{Kg}$ and $100 \mathrm{~kg}$. and body surface areas vere between $1.37 \mathrm{~m}^{2}$ and $2.28 \mathrm{~m}^{2}$. The volunteers were free frow known hypersensitivity to folic acid or its derivatives and had no medical abnormalities which vould, in the opinion of the attending physician, add further risk to the subjects or complicate the study-

Participants were required to abstain from all drugs, including alcohol. for 48 hours prior to the test period. In addition, the participants were asked to fast for 12 hours before drug administration and two hours after dosing.

Leucovorin was prepared for intravenous injection by reconstituting $50 \mathrm{gg}$. of Calcium Leucororin (Lederle Laboratories, lot no. 616-3021 with 5 ml. of sterile water for injection to yield a final concentration of $10 \mathrm{gg}$. 1.- Each subject Ieceived $10 \mathrm{mg}$. of drug innediately after a "zero-tine" or "blank" blood sample was obtained. The collection of subsequent blood samples was scheduled as follows: $5,10,15,20,30,45,60,90,120,180,240,300$, and 360 inutes. The actual tine of each sample collection was documented so that actual sampling times vere available for subsequent analyses.

c. Cancer Patients

Patients undergoing high dose methotrexate-leucororin rescue therapy under the experinental protocols established by the Oncology Section at Roger Rilliams General Hospital. 
page 94

(Appendix III) vere evaluated for possible inclusion in the project. Nine patients were admitted to the MTX program between Norember 1979 and Norember 1980; fire of then were asked to participate in the LEO pharmacokinetics project. Table II details the diagnosis, age, ser, weight, and IEU dose received by each patient. since these patients vere already involved in an experimental protocol (e.g. high dose (IX). participation the the current project required only the patient's consent to obtain appropriate blood saples following the administration of LEJ. This was considered by the physicians inrolved to constitute no additional risk to the patients. All patients vere treated in the clinical oncology unit of the hospital where their blood sanples were obtained by the regular nursing and support staff personnel in the same manner as for the normal" volunteers. All patients were free to terainate the blood sampling at any time, for any reasor.

\section{d. Method of Blood Sample Collection}

an intermittent infusion set, $19 \mathrm{G} \times 2.22 \mathrm{~cm} .$. vas inserted by a physician into a rein on the subject's forearn and carefully taped in place. After drauing a zero time, or blank sanple, the catheter was filled with $0.5 \mathrm{ml}$. of a dilute, 100 units n-2, heparin solution in order to prevent blood clot formation within the tube. at the time of sample collection a latex tourniquet was tightened on the subject's arn abore the position of the catheter, and 
Page 95

TABLE II

METHOTREXATE PATIENT INFORMATION

\begin{tabular}{lcccc} 
Patient & Age & Sex & Diagnosis & Methotrexate Dose \\
\hline F.F. & 48 & M & Osteogenic Sarcoma & $3.71 \mathrm{mg} \mathrm{IV}$ \\
L.M. & 56 & M & Osteogenic Sarcoma & $4.30 \mathrm{mg} \mathrm{IV}$ \\
P.F. & 26 & F & Choriocarcinoma & $1.78 \mathrm{mg} \mathrm{IV}$ \\
F.Y. & 62 & M & Osteogenic Sarcoma & $12 \mathrm{mg} \mathrm{I.M.}$ \\
\end{tabular}


page 96

the heparin solution was withdrawn from the catheter vith a 1 m. disposable syringe. Using a fresh 5 m. disposable syringe with a 216 needle, a 3 to 5 ml. blood sample was carefully withdrawn and placed in a 10 m. "gellow-top" vacutainer tube containing $5 \mathrm{mg}$ of ascorbic acid. The catheter was inmediately flushed with the dilute heparin solution which renained in the catheter until the tine of the next sanple collection.

Blood samples were allowed to clot for at least 1 hour at roon temperature, and were then centrifuged for 10 minutes at $2000 \mathrm{rpm}$. The serum vas carefully remored and placed in $12 \mathrm{~m}$. $x 72 \mathrm{~mm}$. disposable glass test tubes to which had been added $20 \mathrm{ul}$. of a $100 \mathrm{mg}$. m-1 solution of ascorbic acid. The test tubes were then covered with Parafiln and stored frozen until assayed.

\section{e. Extraction Procedure}

Leucovorin was extracted from plasma or serum samples in the following naner. Maters $c-18$ sep-pak cartridge was connected to a $10 \mathrm{ml}$. disposable syringe fron which the plunger had been Ienored. Ten 1 . of methanol was added to the syringe and, using the plunger, slowly pushed through the sep-pak. When all the nethanol had eluted from the Sep-Pak, the cartridge was gently removed from the syringe and the plunger withdrawn once again. After reconnecting the sep-pak cartridge, the process was repeated using 10 1. of a 0.005E (HE4) 2HPO4 buffer, pH 5.5. Again, care vas 
page 97

taken not to force the fluid completely out of the cartridge before remoring it from the syringe.

Following the above two step conditioning process, the plasma or serum sample was loaded through the barrel onto the sep-pak, to be followed by 1 ml. of the ammonium phosphate buffer. This mixture was then slowly forced through the cartridge and the effluent was discarded. An aditional 3 al. of buffer was then eluted through the Sep-pak. Howerer, in this case the plunger was pushed through the barrel with sufficient force to elute essentially all solntion from the sep-pak. The effluent frou this step ras also discarded. The outlet end of the cartridge was then connected to a vacuum tube and the Sep-pak was air-dried for 5 ninutes.

The dried sep-pak was then eluted with $2 \mathrm{ml}$. of nethanol and the eluent collected in sample dishes designed for use in a Fisher todel 190 sample eraporator. The sample dishes vere placed in the evaporator which had been previously heated to $50^{\circ} \mathrm{C}$ and then placed under a vacuun. Nitrogen gas was then allowed to flow slowly into the evaporator until all samples had been evaporated to drypess. An additional 200 al. of methanol was added to each dish; any residue fros the sides of the dish was washed tovard the bottom. This rolume of methanol was also evaporated to dryness. Each saple was then covered with Parafiln, placed in a dessicator, and stored frozen, and protected from light until assayed. 


\section{RESULTS and DISCOSSION}

The electroactivity of a wide variety of organic functional groups i.e.. hydrocarbons, anines or amides, phenols, catecholamines for oxidation, and esters, ketones, aldehydes, diazo, and nitro compounds for reduction have been reported (Fleet and Little, 1977). Howerer, the electrochemistry of conplex organic molecules is not vell understood (Kissinger, 1977). The suitability of electrocherical detection for a compound is best determined by a voltamogra in wich current (generated by the oxidation or reduction of an electroactive species) is plotted as a function of applied roltage.

Samples of calciun leucororin and nethotrerate were shipped to Bioanalytical systens Inc.. R. Lafayette. IN.. to deternine the electroactivity of the folate analogs. Pigures 6 and 7 are the resultant voltamiograms. Calcium lencovorin was dissolved in 0.1 acetate buffer and subjected to an oxidizing potential. No current was detected until the applied potential reached 0.5 volts. The current maximum, approximately 20 nanoans, was achieved at 0.6 rolts. Both figures show an apparent decline in current at higher potential. This is the result of the depletion of oxidizable species in the sample; any applied potential greater than 0.6 volts rould be expected to generate the same current.

Gethotrexate, aissolved in 1 a acetate buffer (with 


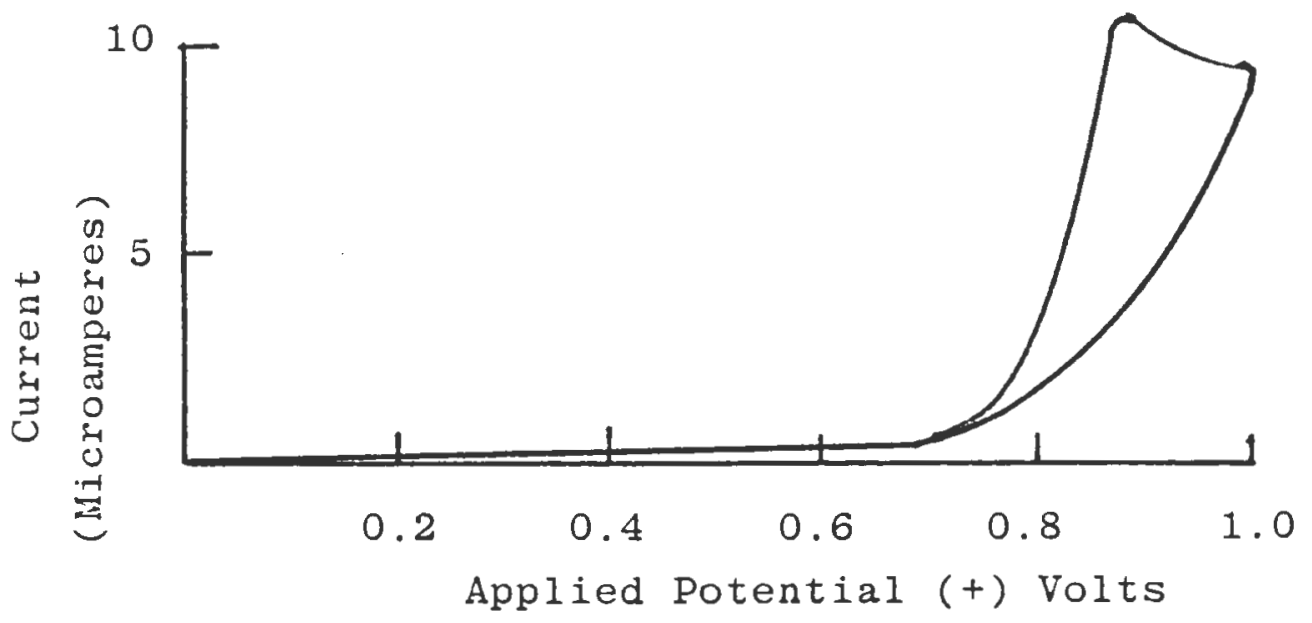

Figure 6: Leucovorin Hydrodynamic Vol tammogram 


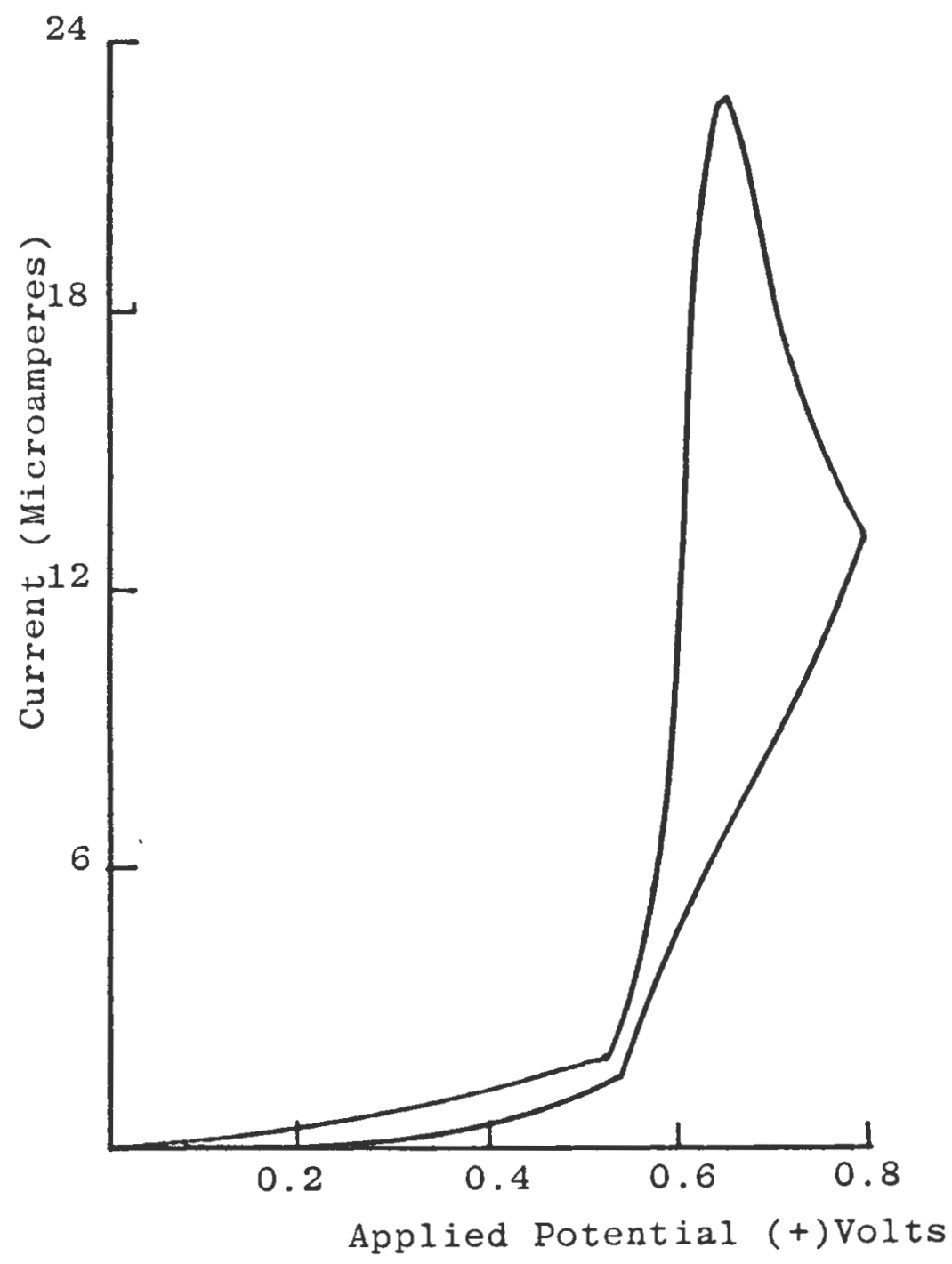

Figure 7: Leucovorin Hydrodynamic Vol tammogram 
page 101

twenty percent amonium carbonate (0.1M) to aid dissolution) produced a peak current of approxiately 10 nicroamps at a potential of 0.8 volts. As ras the case with LEO, the current declined rapidly due to depletion of electroactive species.

Although both compounds were examined under the same conditions, e.g.. voltage scan rate, working electrode, and reference electrode, different nedia vere used to dissolve the drugs. since the bulk solution could vary in characteristics such as resistance and diffusion coefficients, it was difficult to reach conclusions concerning the relative electroactivities of leucororin and methotrexate. Howerer, the voltamograns confira the electroactivity of the folate analogs and the feasability of using amperonetry as a method of detection.

1. Electrode Evaluation

a. Carbon paste, silicone-0il

Carbon paste, silicon oil base electrode material. Cp-0, was evaluated using mobile phases of $20 \%$ to $30 \%$ nethanol in 5n 1-pentane, 1-heptane, or 1-octane sulfonic acid, $\mathrm{pH}$ 3.5. The flow rates used ranged between 0.7 and 1.0 1. per minute. At an applied potential of 1.0 rolt. it uas possible to measure routinely IEU concentrations of $5 \times 10^{-7}$ (50 nanograms). The apparent lover limit of sensitivity was $5 \times 10^{-0}$.

The arerage useful life of a $C p-0$ vorking electrode 
page 102

was only two to three days, contrary to the veeks or wonths of stability reported for this electrode (Kissinger, 1977). The working electrode was considered unusable when the background, or residual current was greater than 90 to 100 nanoanps per rolt applied across the rorking electrode. Becanse four to eight hours of continuous operation vere frequently required for a newly packed or resurfaced electrode to stabilize to low residual currents, the cp-O paste was considered to be unacceptable for routine applications.

The instability of the electrode surface has been artributed to an uneren surface in wich paste can project into the mobile phase flow and flake apart, creating a high background noise. (Reller, et ales 1976). Furthernore, during the packing process, it is possible for some paste to become imbedded in surface imperfections on the electrode block, creating additional residual current (Keller et alse 1976). Air bubbles may become trapped within the paste waterial during the cell packing process. these bubbles ay also contribute to high background current and decreased useful life (Kissinger, 1977). Electrode to electrode reproducibility was inadequate, a Iesult of the naner in which the electrode vell was packed and the surface prepared. Osing the method of cell preparation described previously. electrodes were produced with lower linits of sensitivity ranging fron 5.0x10- a to $1.0 \times 10^{-5}$. The $C p-0$ paste was considered unsuited for 
page 103

routine ase under the chromatographic conditions employed because of the short useful life and the inability to produce electrodes with consistent levels of sensitivity.

b. Max-Impregnated Graphite with silicone 011

One investigator claims that wax-impregnanted

graphite/silicone oil (Cp-D) electrodes are nore durable and more easily resurfaced than previously used carbon pastes (Hosher. 1978). A supply of wax-inpregnated paste. prepared by the method of Atuma and Lindquist (1973) was obtained frow pfizer laboratories, the generous gift of Frank Mosher.

The wax vas evaluated, using obile phases containing $20 x$ to $30 x$ methanol in $5 \mathrm{mg}$ sulfonic acid reagents, pH 3.5. Hobile phase flow rates ranged from 0.7 to $1.0 \mathrm{ml}$. per ninute. At an applied potential of 1 rolt, the lover limit of detection which was achiered with the vax, vas comparable to the cp-O pastes. The baseline noise, or residual current, produced with this electrode was lover than that with the previous systen; fewer noise spikes or randon peaks were generally observed.

The relatively low residual current may be attributable to the ceresin content of the electrode material wich results in a stiffer paste than do nineral or silicone oil-based electrodes. The harder paste can be rigorously "polished" and clearly provides a more uniforn and smooth surface than other pastes. Furthermore, because 
page 104

it is a stiffer material, the wax electrode material is apparently not as susceptible to distortion caused by the motion of mobile phase flowing over its surface. Such distortion is one of the major causes of excessive residual current (Rissinger, 1977).

The average useful life of wax-inpregnanted pastes vas significantly longer than for oil-based electrodes. Two to three veeks of continous operation were frequently possible with cp-n electrodes. As with Cp-O electrodes, wen background currents exceeded 90 to 100 nanoaneres per rolt. it becane necessary to resurface or completely repack the electrode well. Several hours were required to establish a stable baseline current in the range of 20 to 30 nanoamperes per volt following the packing of a new electrode. Increasing the appplied potential to the maximue 1.2 volts did not significantly affect the time required for an electrode to be adequately conditioned. It was not possible to pack the electrode cell and achieve consistent, reproducible detector responses. Two or three cell packings were often necessary to produce an electrode uith a suitable sensitivity and residual current. Despite this disadrantage, $c p-\emptyset$ was routinely used under the chronatographic conditions described above, since an adequately conditioned cell had a useful life five to ten tines that of Cp-o electrodes.

In order to improve the resolution betreen lad and GETH it became necessary to add acetonitrile to the nobile 
page 105

phase. Cp- electrode paste is not stable in mobile phases containing large amouts of organic solrents notably methanol or acetonitrile. Exposure to the ternary nobile phase resulted in the rapid destruction of the electrode surface rendering $c_{p}-n$ inadequate for further use in detecting the reduced folates.

The continued use of wax-impregnanted paste was further hapered by the inabiliy to produce a suitable naterial using the reported nethod (Atuma and linaquist. 1973). Although several batches of the vax-iapregnated paste were manufactured, each resulted in a residual current greater than 100 nanoanperes per rolt which could not be offset electronical1y. thus rendering the electrode useless.

\section{c. Glassy Carbon}

The lack of reproducibility anong electrode surfaces and short useful life inherent in paste electrodes prompted a search for alternate electrode naterial. Fleet and Iittle (1977) suggested that solid electrode voltammetry nay be a useful alternative to pastes and reported a cell design using a piece of highly polished (glassy) carbon as a working electrode. Iankelna and poppe (1976) and Hashimoto and Marugama 1978 have reported on the utility and stability of glassy-carbon electrodes. 


\section{i. Electroactivity of Folate Analogs}

A five mm. glassy-carbon working electrode was obtained from Bio-Analytical systems Inc. and evaluated vith nobile phases containing four to forty percent sethanol, three to fifteen percent acetonitrile and having $\mathrm{pl}$ values ranging fron 3.5 to 7.0 . The applied potential varied from 0.1 to 1.0 volts. The electrode vas exposed to nobile phase flow rates as high as $8.0 \mathrm{ml}$. per minute without apparent danage to the cell surface.

The electroactivity of LEU and METHF was determined over an applied potential range of 0.1 to 0.9 volts. The suming anplifier was set an 50 nanoanperes per rolt. Chromatographic conditions vere: mobile phase II, colum temperature $370 \mathrm{C}$, and a flov rate of $3.0 \mathrm{~m}$. per minute.

Figure 8 is a plot of detector response, measured as log peak height per mole of drug, as a function of applied potential. No current was generated from LEO until the applied potential reached 0.4 rolts. The current produced by LED increased from 0.4 rolts to an apparent plateau between 0.7 and 0.8 volts. The residual current resulting from an applied potential of 0.9 rolts was greater than 100 nanoamperes per volt and therefore could not be compensated for electronically. As a result current produced by the oxidation of leucororin conld not be quantified abore 0.8 volts.

AETHF, unlike LEO, did not produce a measureable 
page 107

current until the applied potential reached 0.3 rolts. Between 0.3 and 0.8 volts the current produced by the oxidation of METHF renained constant. It is apparent from figure 8 that, under the electrochenical and chronatographic conditions described above. METHP is a more readily oridized compound than is IEO. Further, if chromatographic methods vere not able to resolve the two folates, HETHF could be quantified by operating at an applied potential of 0.3 rolts.

Onder the chromatographic and electrochemical conditions described previously, and at an applied potential of 0.8 volts, it vas possible to generate reproducible standard curves of peak height as a function of concentration for both LEU and METHF. A linear response was obtained for both drugs orer the concentration range of

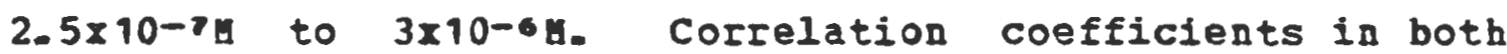
cases were routinely greater than 0.99. Analysis of variance of linear regression shoved a significant correlation for both drugs ( $p<0.05)$.

\section{ii. Durability}

The glassy-carbon electrode has an indefinite useful life. Routine operation with a five n. diameter electrode has been carried out for sixteen months; no treatment other than renewal of the electrode surface has been necessary. Auto-oxidation of the electrode surface and absorption of effluent material are the two factors most responsible 
page 108

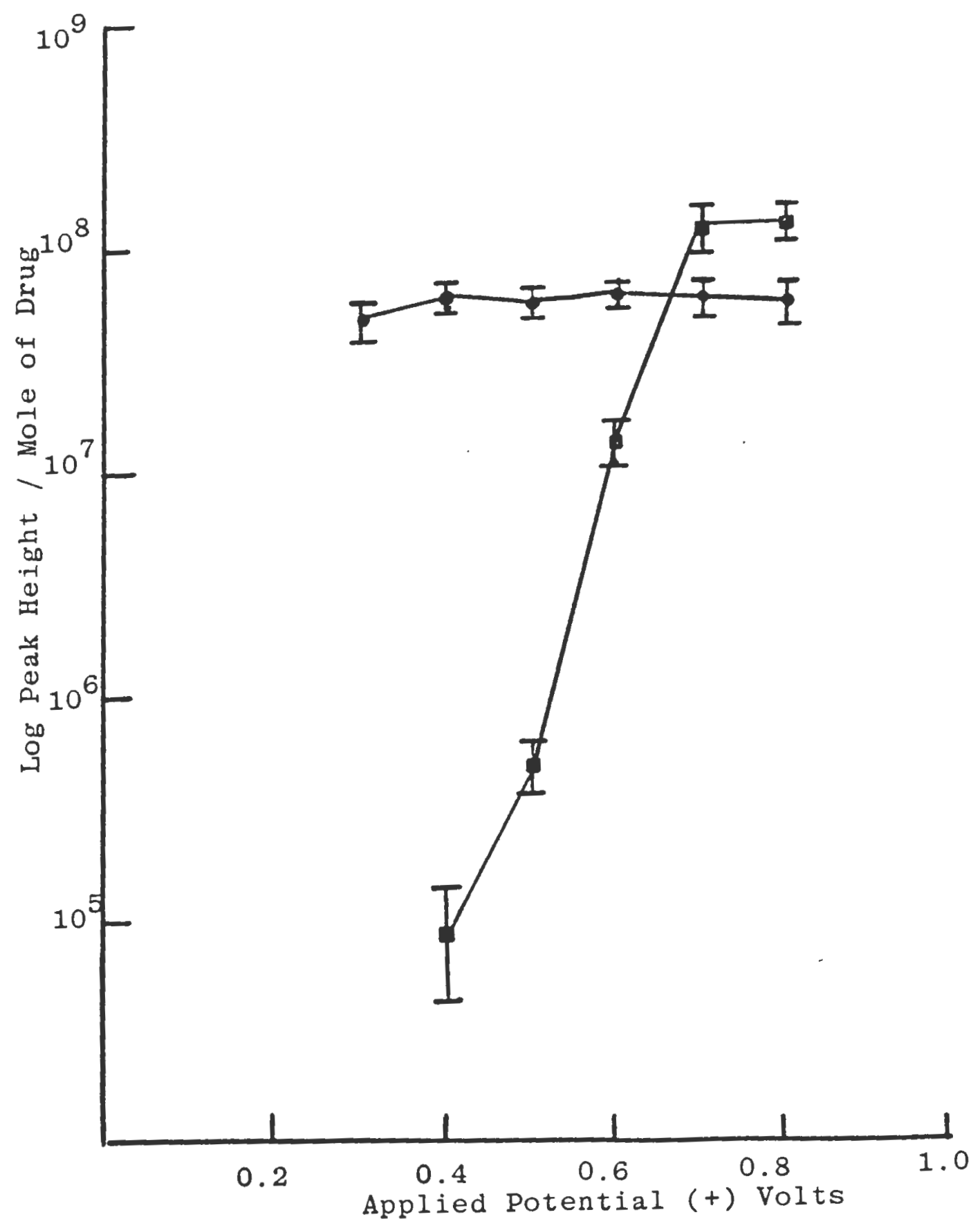

Figure 8: Peak Height as a Function of Applied potential for Leucovorin and Methyltetrahydrofolate 
page 109

for the decrease in sensitivity common to glassy-carbon electrodes (Fleet and Iittle, 1977). After sereral weeks of continuous operation a decline in residual current and sensitivity were observed. Figure 9 represents a series of standard curres, peak height as a function of concentration, generated fron the regression coefficients for leucororin. The constantly decreasing slope evident in A-D. figure 9 clearly demonstrates the loss in sensitivity over a sir-day period of continous operation. Bemoval of the adsorbed material at the electrode surface is all that is usually necessary to reestablish the sensitivity of the electrochemical detector. This was accomplished by rinsing the cell surface with distilled vater, followed by nethanol, and alloving the cell to air dry before being reassenbled. Cycling the applied potential between -2 and +2 volts has been suggested as a means of regenerating a glassy-carbon surface; however, this nethod was not successful. Hechanical removal of adsorbed material was the only adequate weans of restoring the sensitivity of the systen.

\section{iii. Effect of Flov Rate}

The effect of mobile phase velocity on the diffusion lajer thickness (s) within the electrochenical cell and the resulting effect on current jield has been previously discussed. The optimal flow rate, in terms of detector response, for LEO and EETHF was determined by plotting 


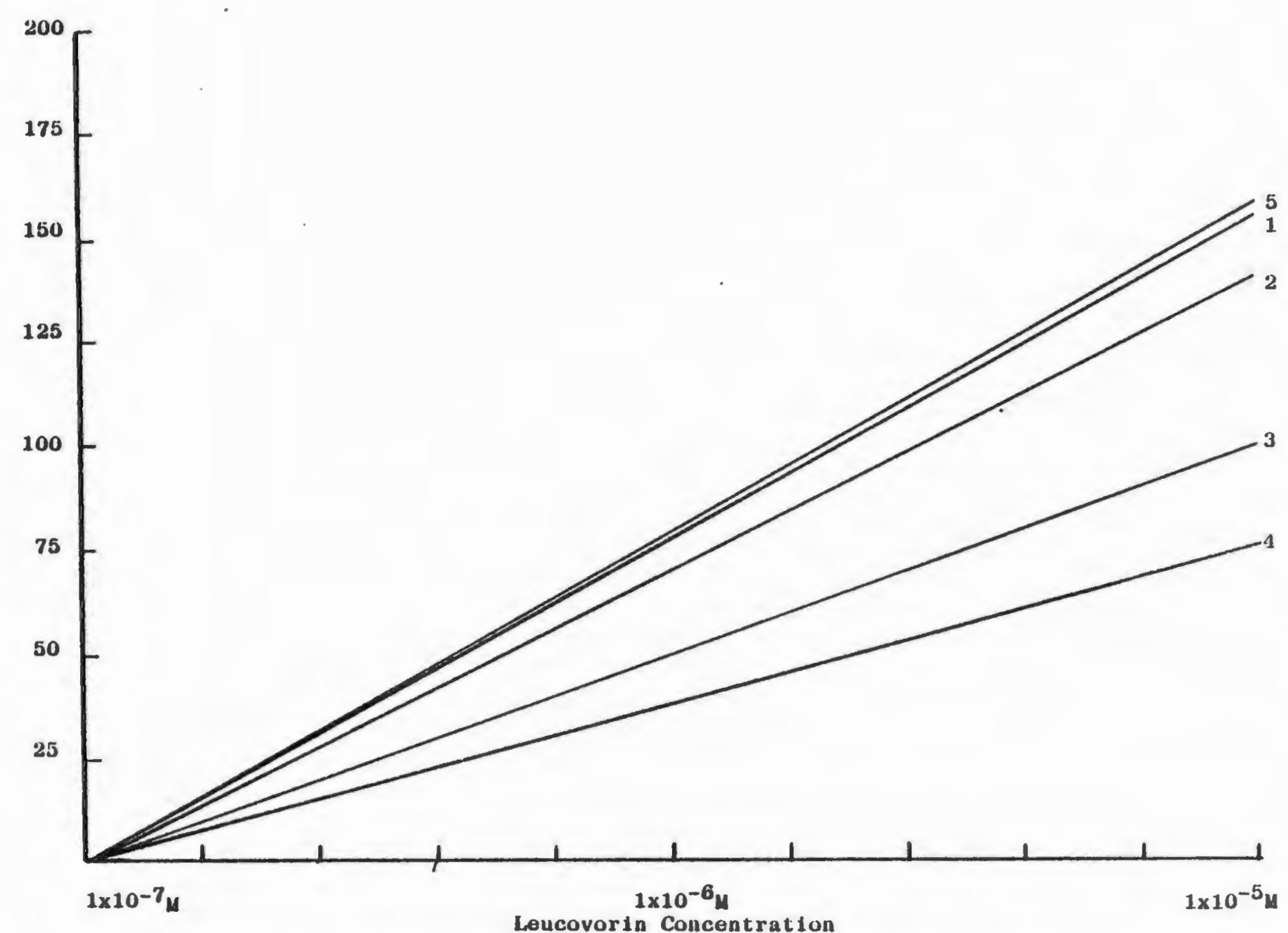

Figure 9; Decline in Detector Response Measured as Peak Height as a Function of Time 
page 111

response, measured as peak height, as a function of flow rate. It is apparent from Pigures 10 and 11 (IED and METHF Iespectively). that peak height decreases with increasing flow rate between 1.0 and 7.0 per minute. One way arova shoved that flow rate had a significant (p<0.05) effect on peak height for both compounds. ANora with linear regression shous a significant linear effect $(p, 0.05)$ for LEU $\left(I^{2}=0.89, n=33\right)$ and for METHP $\left(I^{2}=0.77, n=33\right)$ However, the analysis also showed a significant departure from regression $(p<0.05)$ for both drags. This would suggest that the best model describing peak height as a function of flow rate should allow for curvilinear regression.

although a flow rate of $1.0 \mathrm{~m}$ per minute produced the optimal detector response for botb IEO and HETHF, $3.0 \mathrm{l.}$ per minute vas chosen as the usual operating mobile phase relocity for tro reasons. First, flov rates less than 3.0 n. per minute resulted in unacceptably long chromatographic run times. Secondly. although statistically significant, the difference in peak height at 1.0 versus 3.0 m. per ninute was not considered to be of practical significance and, further, would not appreciably affect either the lover linit or reproducibility of the assay. The use of higher flow rates vas precluded since rates greater than $3.0 \mathrm{ml}$. per minute resulted in loss of resolution between some early eluting peaks as well as loss in detector response evident in Figures 10 and 11. 


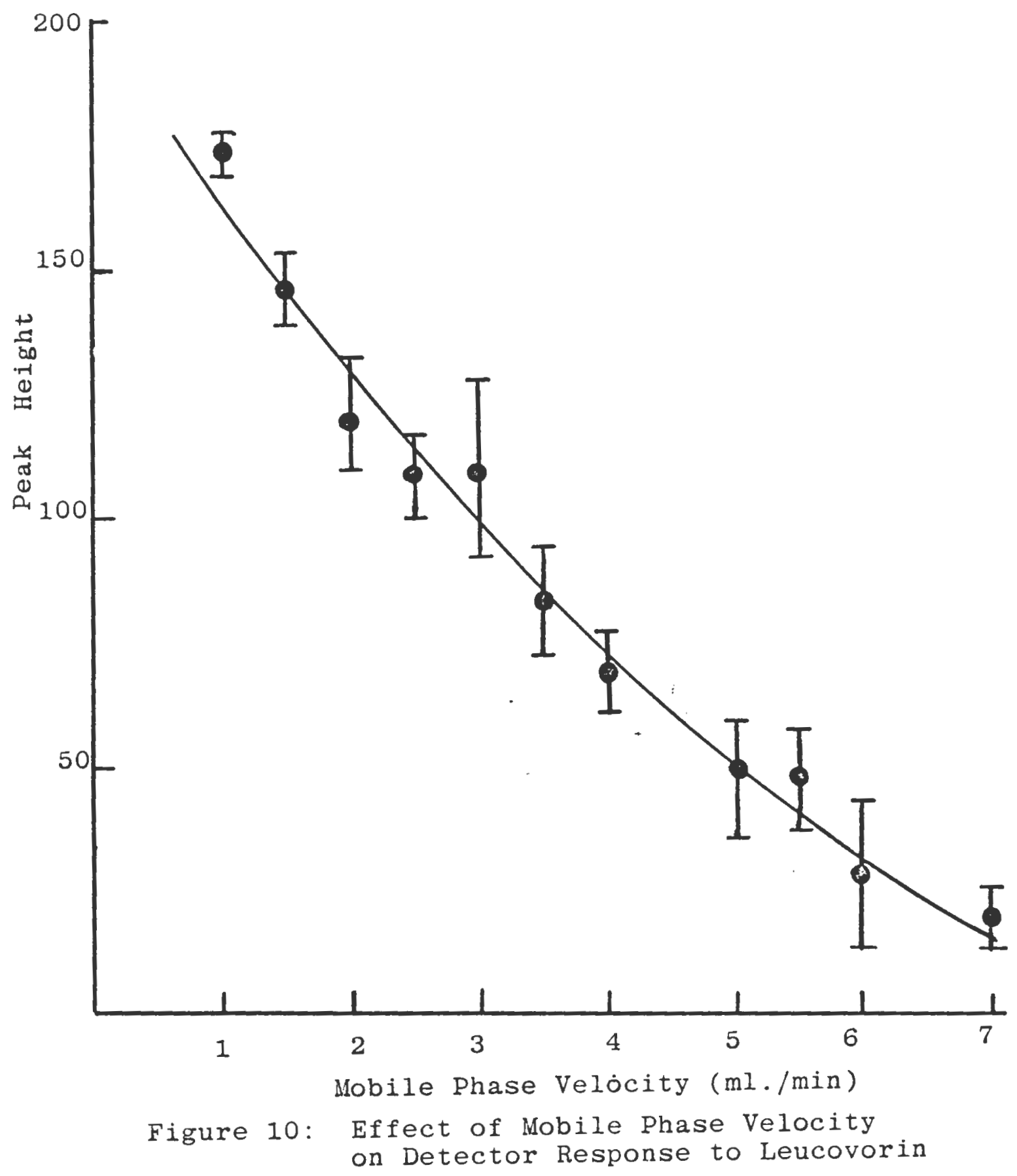




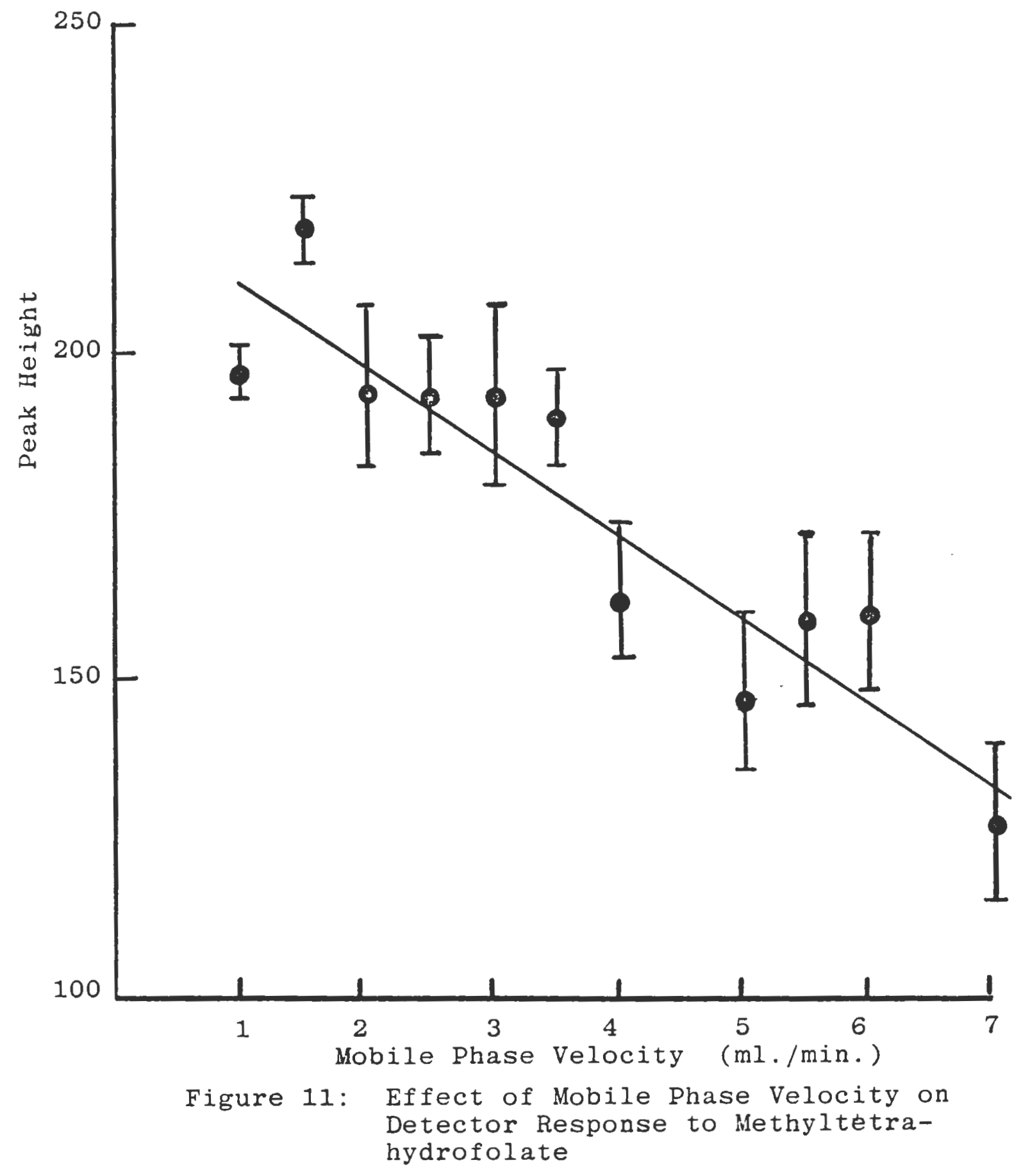


iv. Effect of Salt Concentration

High electrolyte concentrations are necessary in mobile phases to reduce resistance and produce the greatest current at the electrode. Varying concentrations of electrolyte ay also be expected to affect the diffusion coefficient of the electroactive species, which according to equation 6, will affect the liniting current produced at the electrode.

Amonian phosphate, dibasic, was the optinun paired-ion reagent in the separation of the reduced folates. The effect of rarying salt concentrations on detector response was determined for LEO and HETHF (Figures 12 and 13 respectively). The concentration of buffer ranged fron 0.005 to $0.5 \mathrm{a}$ and was increased at one-half log intervals. The $\mathrm{pH}$ of the mobile phase was 5.5 and the flow rate was 3.0 . per inute.

One way arova with linear regression shoved a significant effect $(p<0.05)$ of mobile phase salt strength on response, measured as peak height for both IEO and ABTHF. The plot for lencororin (Pigure 12) is best described by curvilinear regression ( $\left.{ }^{2}=0.98, n=15\right)$. There is a constant increase in response with salt concentration until an apparent plateau is reached between 0.1 and 0.5 salt concentration.

Figure 13 represents ETHF peak height as a function of ammonium phosphate concentration. Rather than increase 


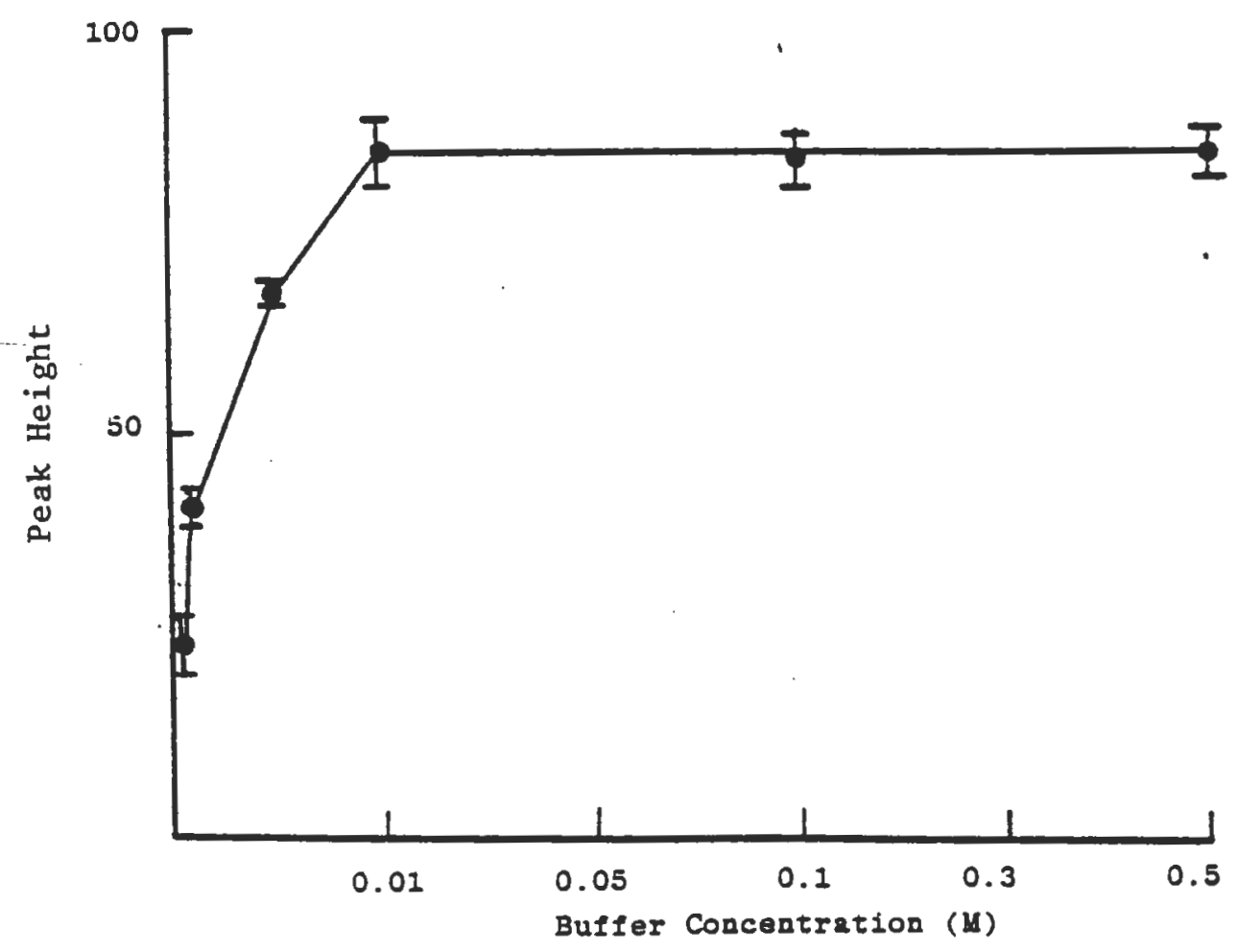

Figure 12: Effect of Buffer Concentration on Leucovorin Peak Height 
Page 116

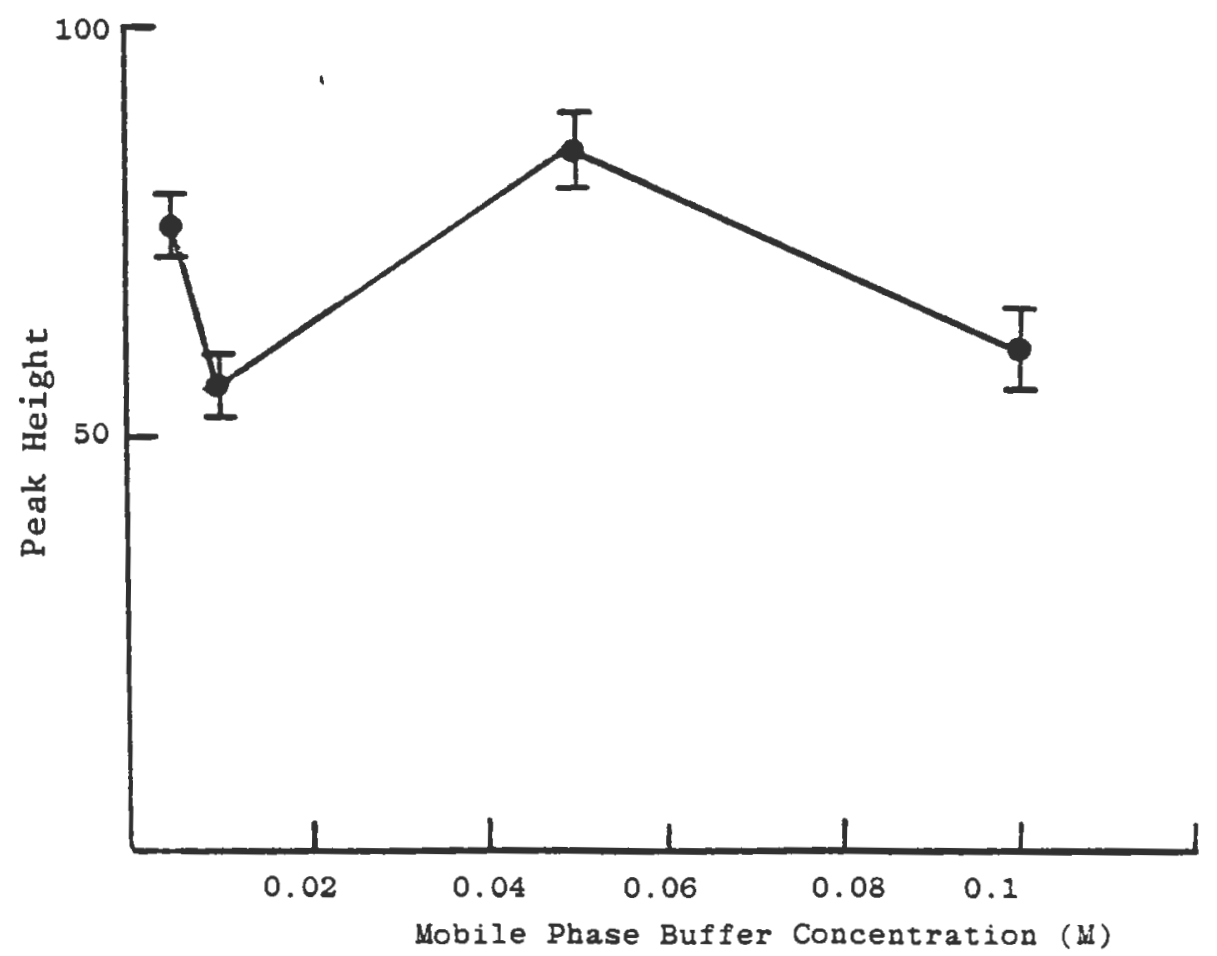

Figure 13: Effect of Buffer Concentration on Methy1tetrahydrofolate Peak Height 
page 117

to a plateau value as was expected, the response of METHF described no discernible pattern. as the salt concentration rose, the response first decreased, then increased and finally decreased to a level lower than the initial salt concentration. This result was unexpected and cannot be explained readily.

\section{Effect of Hethanol on Detector Response}

The elution of the reduced folates from the sep-pak minicolumns required a higher methanol concentration than was present in the mobile phase, e.g., 50\% rersus $4 \%$. Beece and Cozamanis (1979) have reported that samples dissolved in nethanol show decreased detector response and poor Iesolution. They attributed the effect to the high local concentration of organic solvent altering the peak shape and causing band broadening. The effect is particularly pronounced with sample loops larger than fifty to 100 aicroliters and are used for sample loading. The effect of nethanol on detector response to LBU and UETBF was studied by preparing drug standards in solutions containing varping concentrations of aethanol in 0.5 aneoniun phosphate pH 5.5. The electrochenical detector vas set at $+0.8 \nabla$ aplied potential; the suming amplifier was set at 50 nanoaups per volt; and the filter gain was set at 10. The chronatographic conditions for this 
page 118

experinent vere: MPI: with a flow rate of $3.0 \mathrm{ml}$. per minute; and the colunn temperature was $400 \mathrm{C}$.

Figure 14 represents peak height as a function of methanol concentration for LEO and METHF. One way Arova showed a significant methanol effect $(p<0.05)$ on peak height for both compounds. The effect of nethanol was more pronounced on LEO than was the case for GETH. The effect of methanol on LEO can best be described by a straight line $\left(I^{2}=0.94, n=18\right)$. ETHF response is best described by sone curvilinear function $\left(I^{2},=0.92, n=18\right)$. This may be explained by the fact that METHF is apparently a more easily oxidized compond that Leo and, as such, is less subject to variation in response. Contrary to the findings of Reece and Cozaninis (1979). no significant difference in peak width (or resolution) was noted with increasing methanol concentration. Although a high methanol content in injected samples is clearly not desireable, the final organic strength was dictated by the eluent wich removed the folates fron the minicolumn ost efficiently-

\section{B. Chromatography}

Rererse-phase chromatographic nethods are estimated to account for $60 \%$ to $70 \%$ of all analytical work performed using HPLC (Horvath and Mclean, 1977). A review of the recent pharmaceutical and chenical literature shows that reversed-phase systeus, particularly those which use nicroparticulate octadecyl-, octyl-. or phenyl silica 
Page 119

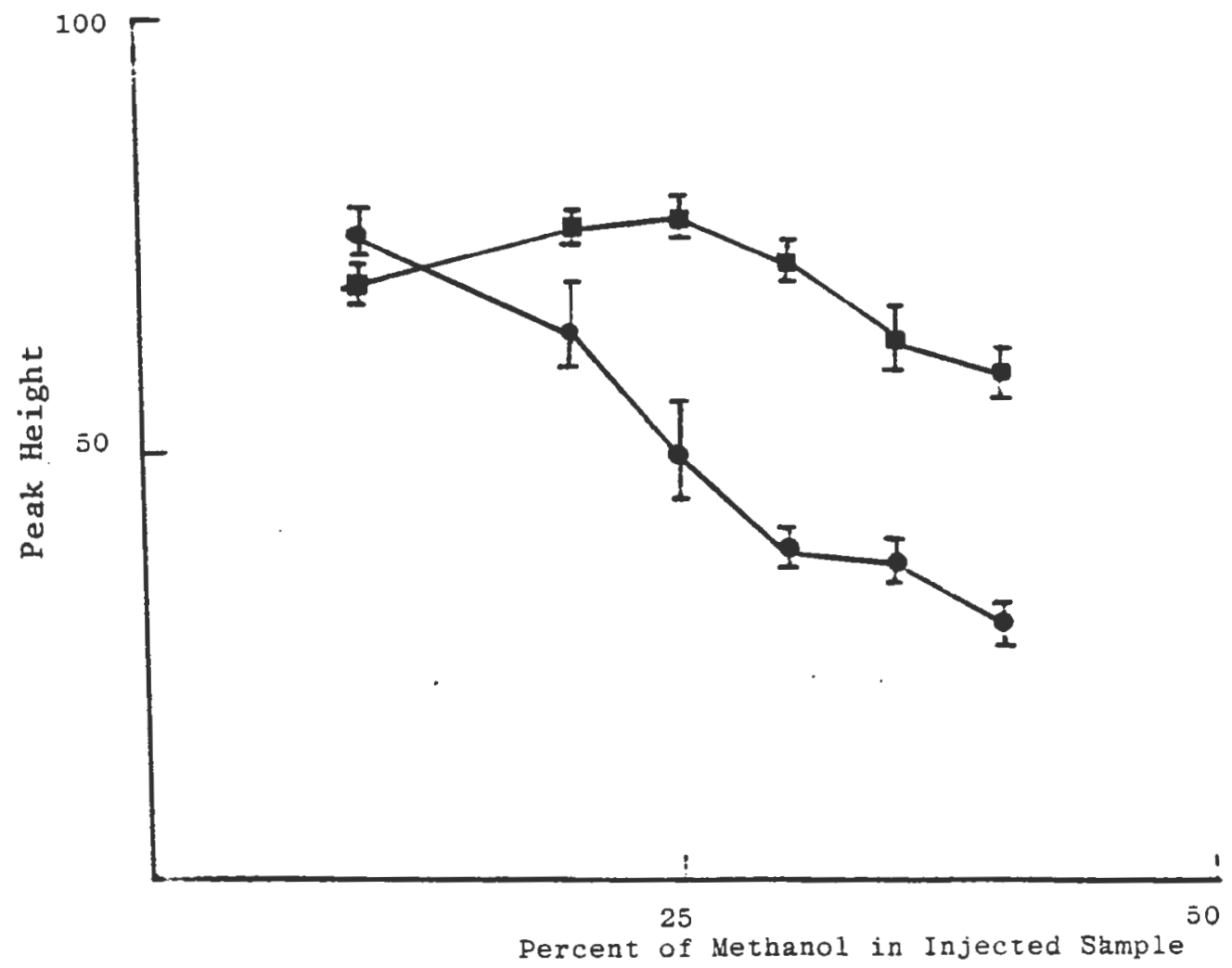

Figure 14: Effect of Methanol on Detector Response for Leucovorin and Methyl tetrahydrofolate 
page 120

stationary phases, are becoming increasingly popular for the analysis of arugs.

\section{C-18 stainless steel Colunn}

A icroparticulate octadecyl-silica stationary phase was chosen for evaluation for three reasons: (1) $\mathrm{ATX}$. structurally related to LEO, has been successfully chromatographed using this systen, (2) stationary phases having high carbon content. 1.e.. octadecyl vs octyl-silica are reported to have a large intrinsic retentive capacity (Horrath and Gclander,1977) and (3) there is a large bod of information available regarding drug analyses employing this stationary phase.

Because the reduced folates to be chromatographed are amphoteric compounds, the use of paired-ion reagents was considered necessary. Gloor and Johnson (1977). Ieported that for strong and reak acids, typical counter-ions such as quaternary anines (tetrabutylammonia chloride for example) are generally used and, that for strong and veak bases alkyl and aryl sulfonates, such as pentane, heptane. and octane sulfonic acids are anong the best choices. The paired-ion reagents best suited for use with amphoteric conpounds is howerer, less well defined. It has been suggested (Rausch, 1977) that sulfonic acids nay provide the best separation of amphoteric compounds similar in structure to the reduced folates.

The most comonly enployed solvent systens in 
Ieversed-phase paired-ion chronatography are water/nethanol or vater/acetonitrile combinations. Therefore, the first mobile phases evaluated were combinations of nethanol and water with $5 m$ MIC B5, (pentane sulfonic acid, Vaters Assoc.). Figure 15 is the chromatogram resulting from the separation and detection of 1×10-6 LEO in a nobile phase consisting of 25\% MeOH: 75\% PiC B5. p3.5. The retention of LEO was found to be 7.25 minutes. The peak hoverer, was broad, and eluted orer a prolonged, 4 minute period. In adition the systen was not suitably sensitive, as is evident from the small peak obtained for LEO.

Various combinations of paired-ion reagents, organic solvents, and pH's vere prepared and evaluated. Three factors were considered in the evaluation of a mobile phase: capacity. selectivity and sensitivity for the reduced folates.

Capacity may be calculated according to Equation $x x$ and ay be defined as the ability of a chromatographic system to retain a compound.

$$
\mathbf{k}^{\prime}=\frac{\mathrm{V}_{\mathrm{t}}-\mathrm{V}_{\mathrm{o}}}{\mathrm{V}_{\mathrm{o}}}
$$

(Equation 18)

Where $\nabla t$ is the retention rolune (or time) of the compound of interest, and vo is the roid rolune or rolume in which a non-retained compound would elute. selectirity is the ratio of 2 capacity factors and 
page 122

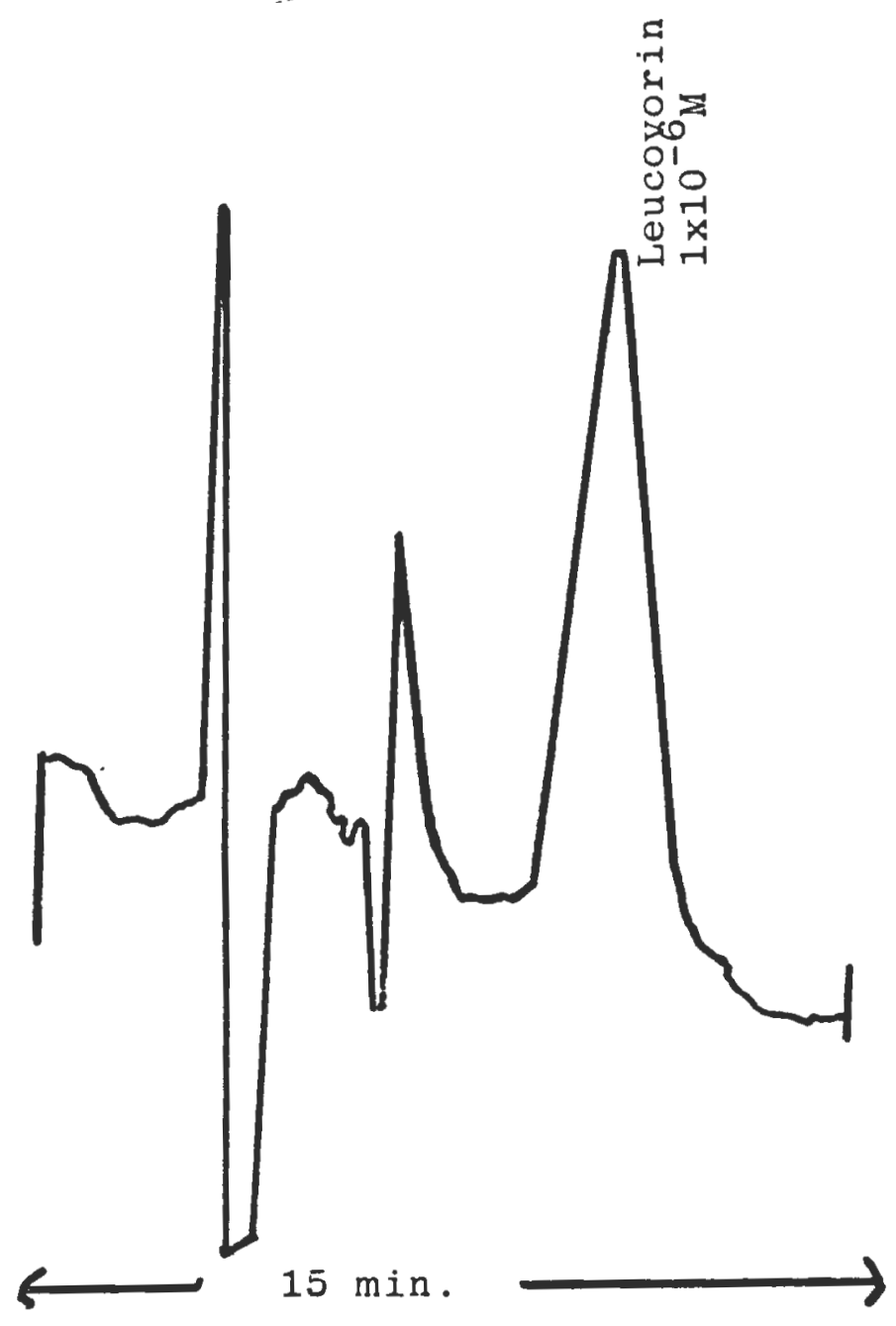

Figure 15: Leucovor in Chromatogram using Paired-Ion Reagent ${ }^{B_{7}}$ 
page 123

describes the ability of the system to separate two compounds.

Table III shows representative mobile phase conpositions used with the microparticulate C-18 colun. and the resulting capacities and selectivities which were obtained. Figure 16 is the chromatogran of what was considered the optimu separation obtained from the reduced folate analogs wich could be detected. In general the capacities calculated for LEO were relatively low. while those obtained for METH considerably larger.

The addition of aqueous buffer to sone of the mobile phase systens described in Table III was the result of the poor sensitivity obtained from systems containing only paired-ion reagents. Such systens have relatively high resistance, and as a result the current produced fron the oridation of a sample is low. The increased ionic strength of mobile phases containing the various buffers increased sensitivity but, in general, had a negatire effect on capacities, resolution, and efficiencies.

A reported adrantage of reversed-phase paired-ion chromatography is the ability to make direct injection of biological fluids without prior extraction or sample "clean-up" (Johansson et $\underline{\text { al }}=$ 1979). This, hoverer, was not possible under the chromatographic conditions employed. Plasma or serum injected directly onto colunns produced chromatograms of (presumably) polar compounds eluting for longer than 20 minutes, and less polar compounds still 
TABLE III

REPRESENTATIVE MOBILE PHASE COMPOSITIONS

USED WITH REVERSE-PHASE C-18

STAINLESS STEEL COLUMNS

Mobile Phase

Retention Time (Min.)

LEU

METHF

(1) Octane Sulfonic Acid: $\mathrm{CH}_{3} \mathrm{OH}$ :

7.5

26.5

$\mathrm{CH}_{3} \mathrm{CN} ; 70: 25: 5 ; \mathrm{pH} 3.5$

(2) Octane Sulfonic Acid: $\mathrm{CH}_{3} \mathrm{OH}$ :

7.5

20.5

$\mathrm{CH}_{3} \mathrm{CN} ; 70: 22: 8 ; \mathrm{pH} 3.5$

(3) Acetic Acid: Sodium Acetate 0.1M:

10.0

10.0

$\mathrm{CH}_{3} \mathrm{CN} ; 75: 25 ; \mathrm{pH} 4.5$

(4) Heptane Sulfonic Acid: $\mathrm{CH}_{3} \mathrm{OH}$ :

12.9

20.0 $\mathrm{CH}_{3} \mathrm{CN} ; 82: 15: 3 ; \mathrm{pH} 3.0$

(5) Heptane Sulfonic Acid: .01M in $\mathrm{KH}_{2}$

17.07

8.23 P04: $\mathrm{CH}_{3} \mathrm{OH}: \mathrm{CH}_{3} \mathrm{CN} ; 80: 17: 3$ $\mathrm{pH} 3.0$

(6) $\left(\mathrm{NH}_{4}\right)_{2} \mathrm{HPO}_{4}$ 50mM: $\mathrm{CH}_{3} \mathrm{OH}: \mathrm{CH}_{3} \mathrm{CN}$;

4.52

3.75 80: $17: 3 ; \mathrm{pH} 6.5$ 
page 125

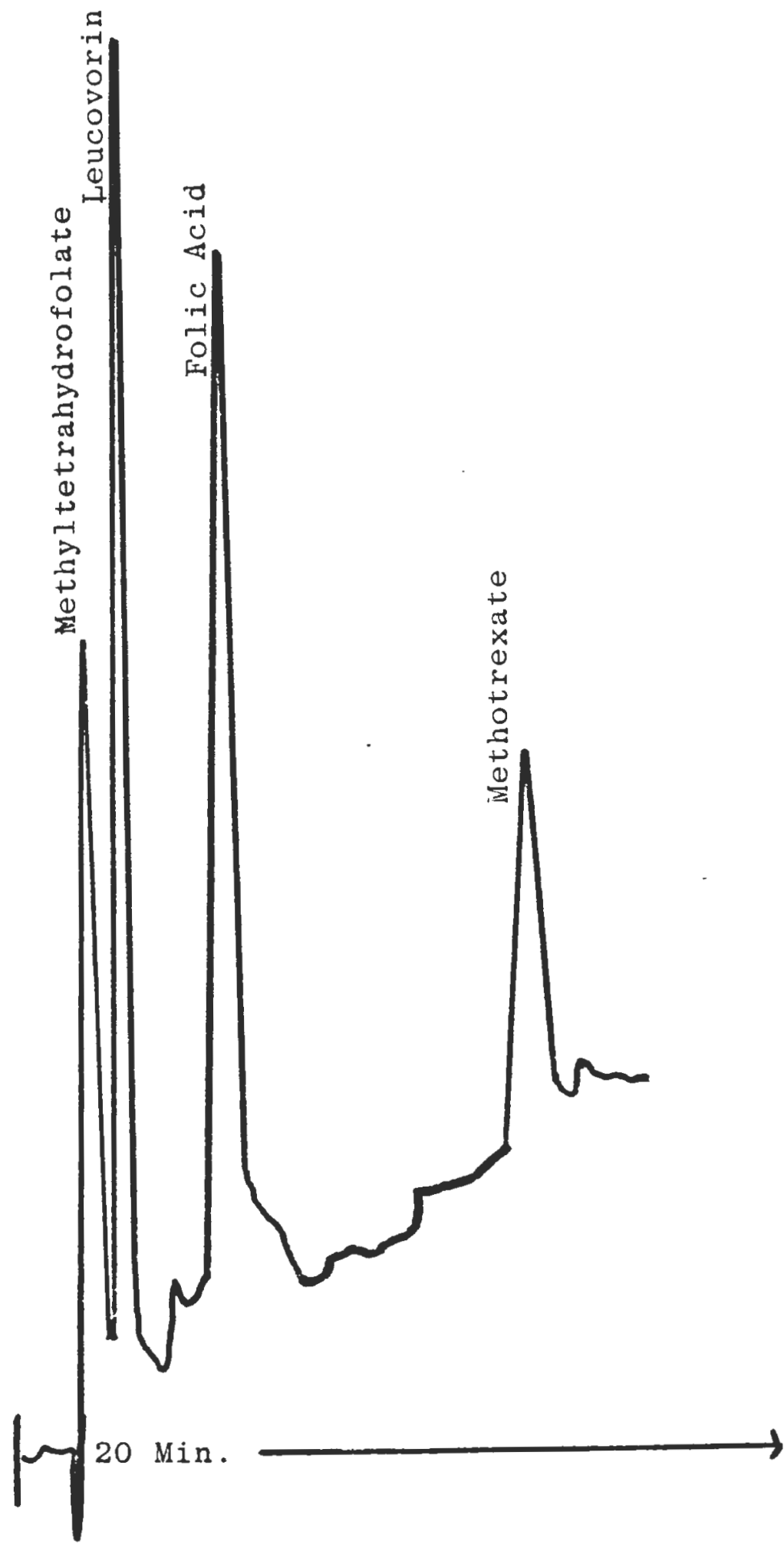

Figure 16: Resolution of Folate Analogs Using C-18 Stainless Steel Column 
page 126

evident 60 minutes after injection. similar reports of interfering compounds adversely effecting electrochemical detectors have been published by kissinger (1974) and Lankelma and Van der Kleijn (1978).

It was not possible to derise a separation systen using the $\mathrm{C}-18$ coluna which could suitably separate the reduced folates fron plasma constituents.

\section{Radial Compression separation system}

a recent adrance in analytical liquid chronatographic technology is the developwent of radial corpression column systems. Radial compression has been reported to have several adrantages orer conrentional stainless steel column technology including: high efficiercy at higher flow rates, increased resolation, greater colunn to colunn

reproducibility. lov systen operating back-pressures, and longer colum life. The operation of this system and its adrantages have been reviewed recently by fallick and Rausch (1979) and Little et als (1976).

a. Evaluation of the Radial Compression

A Radial Compression separation systea (BCSS) was evaluated for its applicability to the separation of reduced folates in aqueous systems and seram. The column used for this purpose was an octadecyl-silane reverse-phase materal with an 8 ma I.D. and a 3.0 al internal volune.

Dibasic ameniua phosphate, (NH4) 2EPO4, was considered 
page 127

the most pronising buffer, with respect to resolution and sensitivity achiered on C-18 packing waterial, and was the paired-ion agent first used in evaluating RCSS technology-

Chromatographic conditions suitable for conventional reversed-phase separations nay not be directly applicable to the RCSS technology- Decreasing the organic solvent strength by approximately one-half of that in a conventional systen has been recommended as a means of obtaining a suitable mobile phase from which to experiment. Because of the reported differences in performance between the two chromatographic methods and the paucity of published data regarding its operation, a characterization of several. RCSS operating paraneters, with respect to reduced folates, was undertaken. The four characteristics used to eraluate the RCSS were: mobile phase flou rate; colunn tenperature: buffer strength; and pH.

\section{i. Effects of Flow Rate}

The large internal rolume and shorter length of the radial pak cartridge, in conparison to conventional stainless steel colunns, results in lower operating pressures for ang giren flow rate. As a result, it was possible to operate the RCSS at flou rates as high as 6.0 1 min-t without exceeding back-pressures of 2000 psi. Figure 17 is a plot of the retention times as a function of flow rate for both IEO and METhF. The mobile phase used in these determinations yas 0.5 (8H4) 2 HPO4 93\%, CB3CN $3 x_{\text {. }}$ 
page 128

CH3OH 4\%, pH 5.5. Conventional chromatographic systems are linited to flow rates of 1.5 to $2.0 \mathrm{ml}$ min-1. higher rates exceed colum back-pressures of 2000 psi and may damage the packing material. over these limited solvent flou rates, plots of retention times as a function of flov rate are linear. Bowever, hen higher flow rates were used, deviations frov linearity were evident. It is apparent fro this figure that both the capacity and selectivity of the RCSS decreased with an increase in flow rate above 3.0 to 4.0 win-2. Figure 18 is a log-log transformation of the retention times as a function of flow rate. The linear regression coefficients obtained from this plot vere subsequently used to predict the retention of IEO and ETRF during the development of optimal mobile phase conditions. It was possible to extrapolate this data from the nobile phase tested and predict retentions in other mobile phase systems as aight be expected. These observations are in general agreement with studies of flow control in BPLC reported by schrenker (1978).

\section{ii. Effects of Tenperature}

"In HPLC there has been a tendency to overlook the influence of temperature on chromatographic measurements" (Gilpin and Sisco 1978). These authors report that both normal and bonded phases aay be affected by teaperature, and that rariations in capacity greater than $25 \%$ have been observed with tenperature changes of $10 \mathrm{C}$. or less. Because 


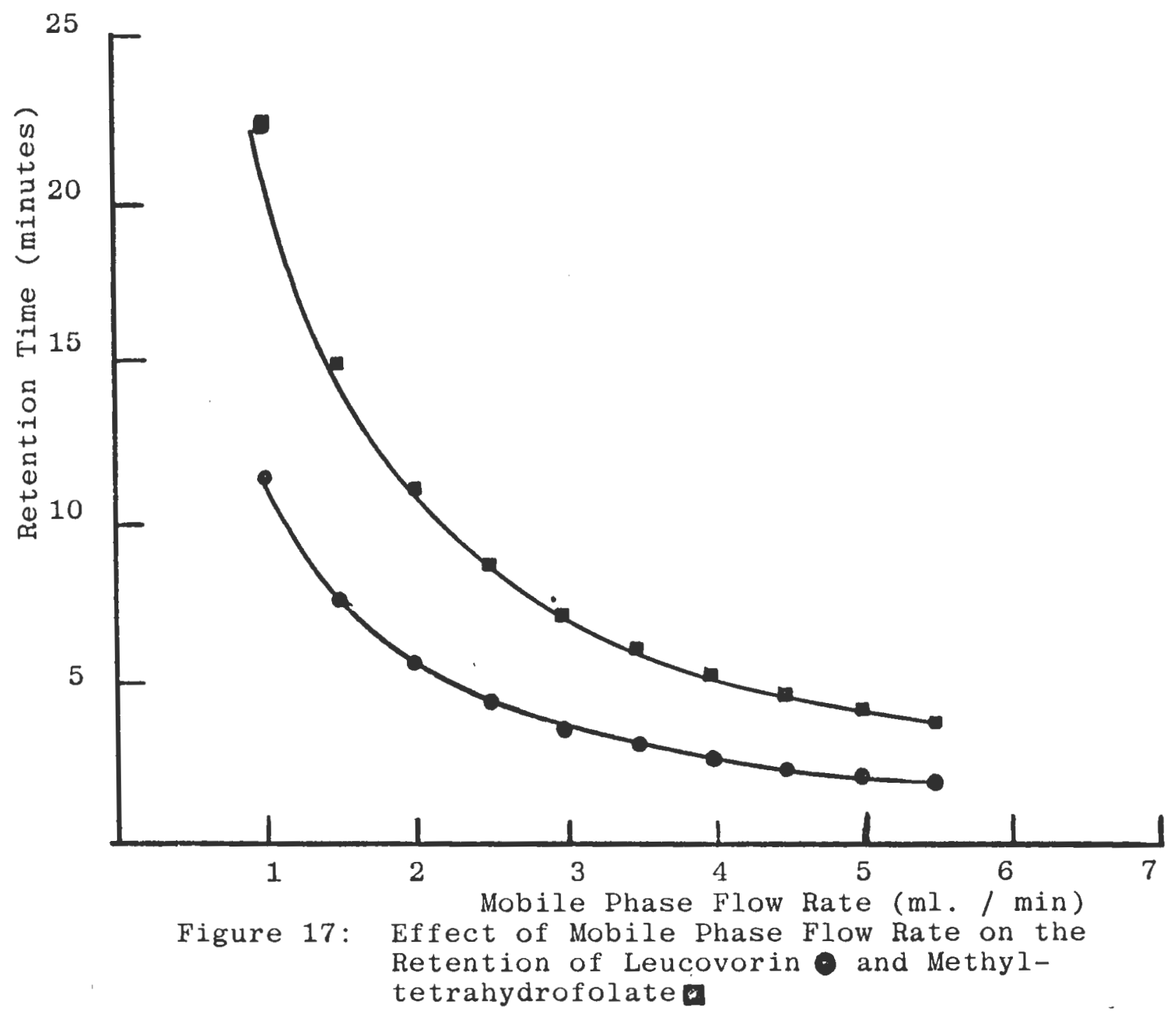




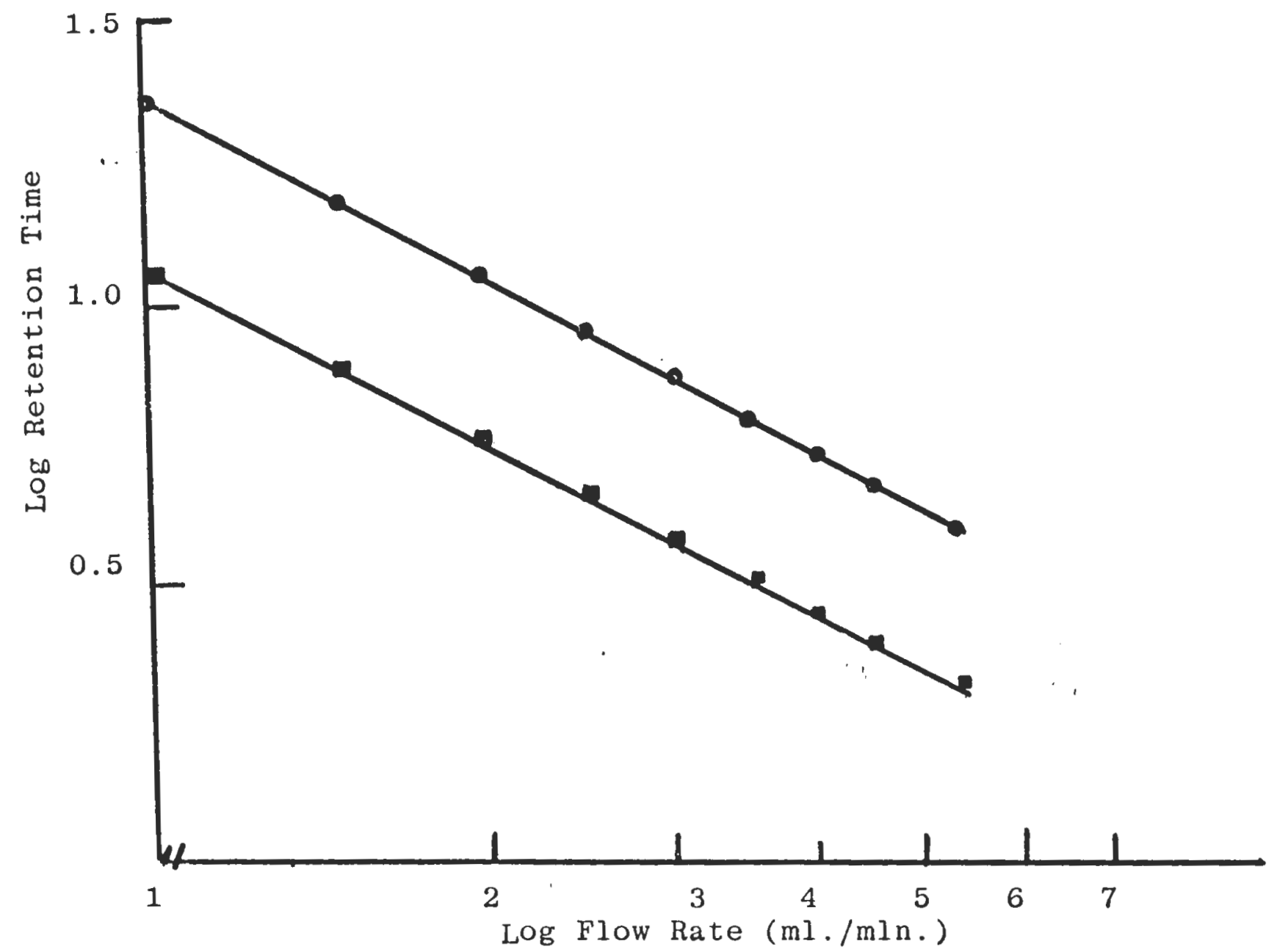

Figure 18: Log-Log Transformation of Retention Time as a Function of Flow Rate Leucovorin Methyltetrahydrofolate 
page 131

of the high efficiency and reactivity associated vith RCSS colunns the effect of temperature on retention times of LEU and METHF vas investigated.

Table IV is a comparison of LEO and HETHF retention and the corresponding colum selectivity calculated at $20^{\circ} \mathrm{C}, 30^{\circ} \mathrm{C}, 40^{\circ} \mathrm{C}$, and $50^{\circ} \mathrm{C}$. Pigure 19 shous the

chronatograns obtained from the injection of a IEO-uRTHF conbination at $20^{\circ} \mathrm{C}$ and $50^{\circ} \mathrm{C}$. The decrease in retention times (capacity) at the two temperatures is evident. hoverer, the selectivity of the system actually inproved at the higher tenperature. This can best be explained by a decrease in both IEU and METHF peak width.

Tenperature fluctuations were found to affect daily chronatographic results. ambient teaperatures fluctuated as nuch as $10^{\circ} \mathrm{C}$. during the course of a day. causing as much as $20 \%$ changes in observed retention times for folate compounds using the same mobile phase. The installation of a Thelco. Hodel 15. constant temperature oren, circumvented the effects of temperature. Column temperatures vere held constant at $40^{\circ} \mathrm{C} \pm 3^{\circ} \mathrm{C}$ and retention times for LEO and aETHF vere found to be reproducible within the $5 \%$ linits of the RCSS systen.

\section{iii. Effects of counter-Ion strength}

The effect of counter-ion (buffer) concentration on the retention of LEO and IETHP was characterized during the evaluation of nobile phase characteristics. 
TABLE IV

EFFECT OF TEMPERATURE

ON FOLATE RETENTION

Temperature $\left({ }^{\circ} \mathrm{C}\right)$
Retention Time (Minutes)
Selectivity ( $\alpha)$

\begin{tabular}{lccc}
\hline $20^{\circ}$ & $\frac{\text { LEU }}{4.60}$ & $\frac{5 \text {-METHYL }}{8.10}$ & 1.95 \\
$30^{\circ}$ & 4.13 & 7.52 & 1.89 \\
$40^{\circ}$ & 3.50 & 6.59 & 2.27 \\
$50^{\circ}$ & 2.68 & 4.90 & 2.36 \\
\hline
\end{tabular}


page 133
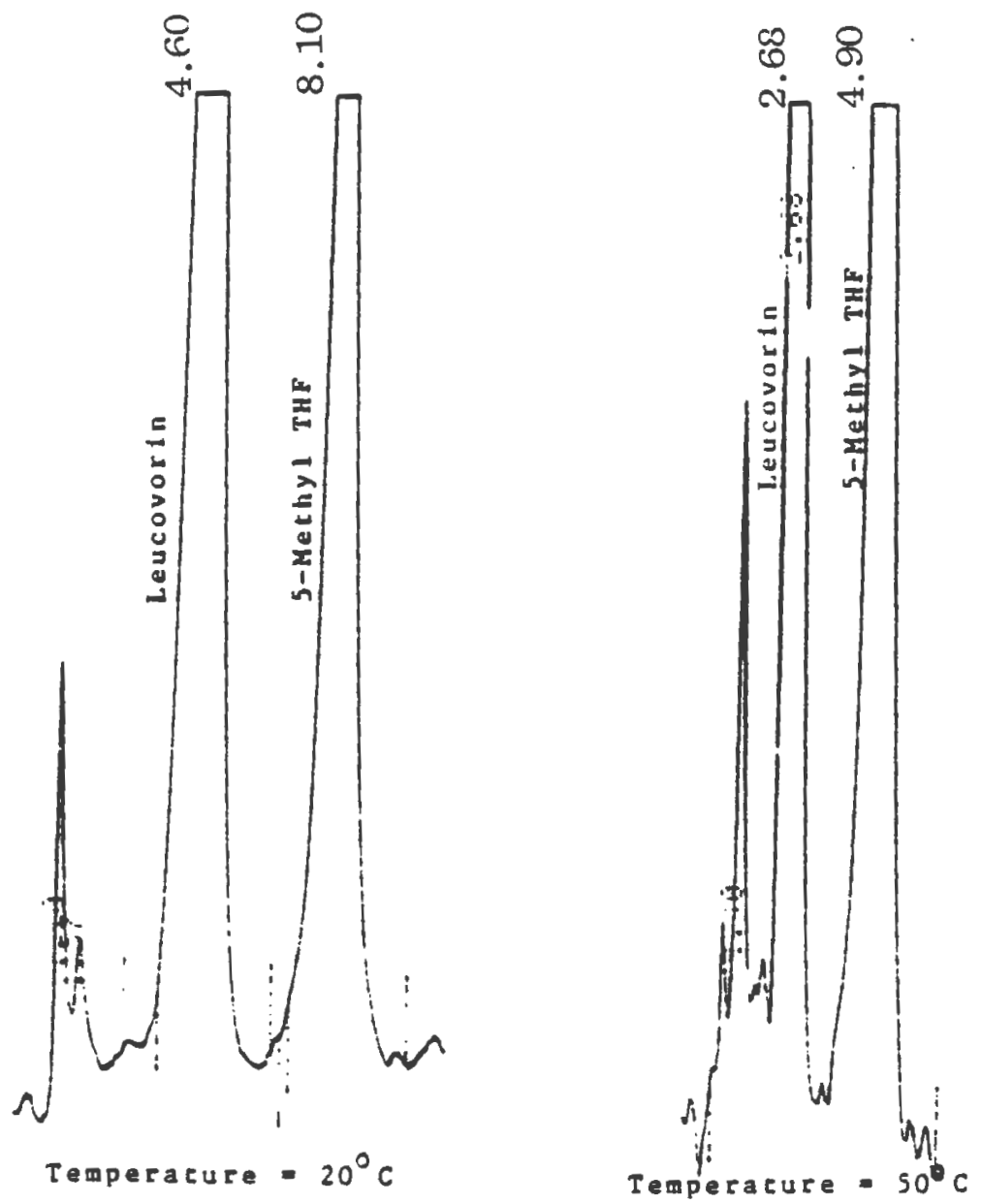

Figure 19: Effect of Column Temperature on Leucovorin and Methyltetrahydrofolate Retention. 
page 134

The nobile phase contained Buffer:MeOH:CB3CN in the ratio 93:4:3. The $p$ Has maintained at 5.5. Table $\nabla$ describes the retention times for IEO and METHF as a function of ammonium phosphate concentration. Although the mechanism of the ion-pail reaction is unclear fGloor and Johnson. 1977) and is further clouded by the presence of positive and negative counter-ions fron the amoniua phosphate, the general trend is in agreenent vith published data suggesting that increasing counter-ion concentration increases retention up to a liniting ralue.

\section{iv. Effect of $\mathrm{pH}$}

The effect of $\mathrm{pH}$ is dependent upon the nature of the solute. Hoverer, retention increases as changes in pH tend to maximize the concentration of the ionic form of the solute. This presuably increases the equilibrium in faror of the ion-pair complex. Pigure 20 is a plot of the retention of LEO and METHF as a function of $p H$. The nobile phase used was $0.5 \mathrm{H}$ Phosphate Buffer: $\mathrm{CH} 30 \mathrm{H}: \mathrm{ch} 3 \mathrm{cn}$ in the ratio 93:4:3. It is evident that $\mathrm{pH}$ affects LEO retention to a greater degree than it does METHF. This result houever, is not easily explained. Although pKa values have not been reported for UETEF it vould seem likely that it rould have ralues similar to those of LEO. Both compounds have the same ionizable groups, e.g. $c 4$ hydroxyl group, and 2 glutanyl carboryl groups. It would seen likely that the disassociation of these groups rould be similar 
TABLE V

THE EFFECT OF BUFFER CONCENTRATION

ON FOLATE RETENTION

\begin{tabular}{|c|c|c|}
\hline Buffer Molarity & LEU & METHF \\
\hline 0.5 & 3.85 & 7.49 \\
\hline 0.3 & 3.79 & 6.76 \\
\hline 0.1 & 2.91 & 6.06 \\
\hline 0.05 & 2.62 & 5.66 \\
\hline 0.01 & 1.63 & 3.66 \\
\hline 0.005 & 1.57 & 2.06 \\
\hline
\end{tabular}

Mobile Phase Composition:

Buffer: $\quad \mathrm{CH}_{3} \mathrm{OH}: \mathrm{CH}_{3} \mathrm{CN} ; 92: 4.5: 3.5 \mathrm{pH} 5.5$

Flow Rate $=3.0 \mathrm{ml} / \mathrm{min}$. 


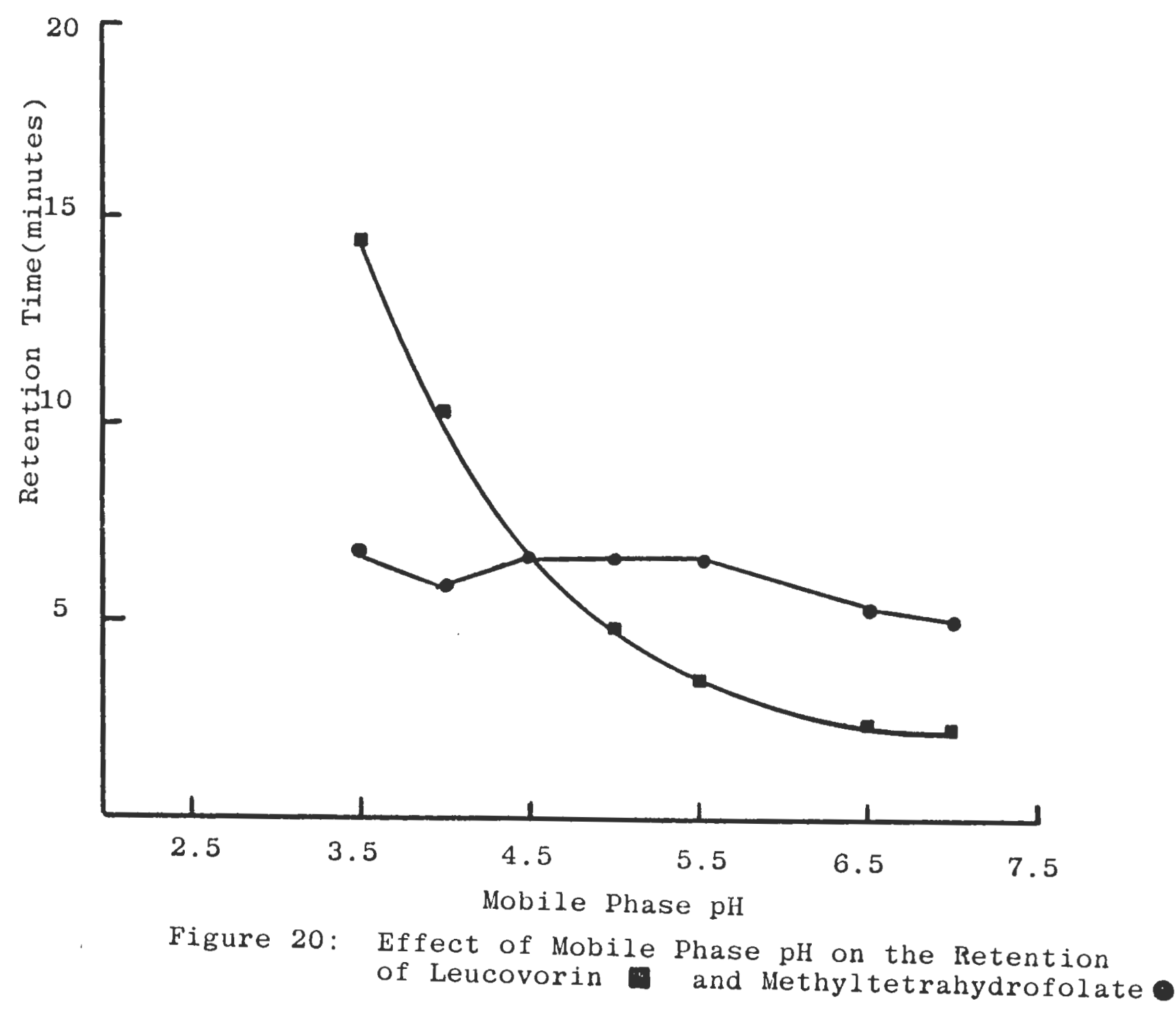


page 137

for both conpounds. since the only structural difference between LED and घETHF is in the Ns substituent, formyl and methyl respectively, these data suggest that the functional group in this position contributes to the retention characteristics of these reduced folate analogs.

\section{Drug Assay \\ 1. Aqueous systens}

The electrochenical detector response to LED or METHF. neasured as peak height, declined rapidly fron a naxinu value observed immediately after the cell was resurfaced. as a result, it was necessary to generate standard curves of peak height as a function of concentration. whenever quantitative measures were to be performed.

Calciun LEO OI Bariun METHF were used as received without further purification. IEO and METHF solutions of

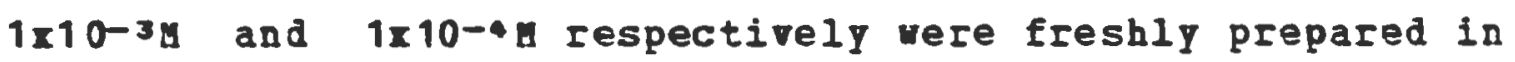
1N xoH. $\quad 11$ further dilutions vere made with the solvent in which the drug was to be chronatographed; Sorenson's Buffer for protein binding (LEO or ateTHF) or, mobile phase for IEU serun concentrations. All drag solutions prepared in this manner were protected fros light with aluminun foil and stored on ice. Fresh stock solutions vere prepared daily. No degradation in either drug solution was noted; no detectable changes in peak heights of the chromatograns or by changes in the shape of peaks or by the appearance of other peaks or shoulders in the chromatograms during the 
course of an experiment.

Standard curves for both $L E O$ and HETHP were generated by plotting peak height as a function of drug concentration. Drug concentrations for this purpose vere between $2.5 \times 10^{-18}$ and $5.0 \times 10^{-6}$. At least 5 concentrations vere used to generate these standard curves. Each point represents the average of 2 determinations; each concentration vas deterained in triplicate. Thus, each standard curve consisted of at least 15 data points. A linear plot vas obtained orer the concentration range specified for both drugs (I2>0.99 in all cases). All unknown solutions vere analgzed in duplicate and concentrations were determined from the regressions coefficients of the appropriate standard curve.

\section{Serum}

A LEO stock solution, $1 \times 10^{-3} \mathrm{H}$, in $1 \mathrm{H}$ KOH, was prepared, and from this stock solution, additions vere made to pooled human serum to rield final IEU concentrations

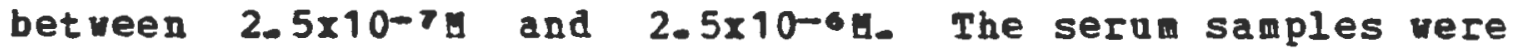
then extracted in the manner described previously. A11 samples vere analyzed the sane day as extracted.

The evaporated serua samples vere reconstituted in 0.5 al of mobile phase. since the extraction was carried out with $1.0 \mathrm{al}$ of serua, this represents a two-fold concentration of sample. Care was taken to rinse the walls of the sample dish to insure collection of the entire 
sample. Identity of the IEO peak in the sample matrix was confirmed by analyzing serum-blanks which erhibited no peaks with retention tiaes corresponding to LEU, and by the addition of IEO to reconstituted samples and noting an increase in the height of the peak identified as IEU.

\section{a. Recovery}

The recovery of LEO added to pooled human serum was virtually complete. The recovery over the concentration range studied was 101.11\%, with a range in recoveries of 93.60\% to 117.20\%. Table VI shows the amount of LEU added to serun saples, the calculated amount of led measured and the percent recovery at each concentration. Figure 21 is a plot of the observed IEd concentration as a function of the known IEO concentration in each sample. A plot of LEO peak height as a function of concentration was linear orer the concentration range $2.5 \times 10^{-7} \mathrm{H}$ to $2.5 \times 10^{-6} \mathrm{H}_{\text {. A }}$ statistical analysis of the regression coefficients obtained from standard curves of LEO in serum and mobile phase was perforned. No difference $(p<0.05)$ was noted in the slope of the regression. The intercepts, however, showed a signficant difference $(p<0.05)$. those obtained froa LEO in serum vere larger than from aqueous systens. Although the differences in y-axis intercepts were statistically different $(p<0.05)$. the error caused by using the regression coefficients obtained from LEO in mobile phase 
TABLE VI

RECOVERY OF LEUCOVORIN FROM HUMAN SERUM

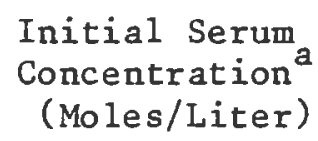

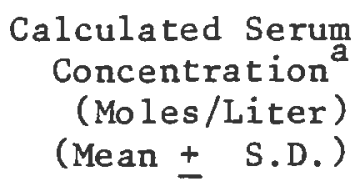

Average Percent Recovery +

$\begin{array}{lll}2.34 & \pm 0.30 & 93.60 \\ 5.0 & 5.86 \pm 0.60 & 117.20 \\ 7.5 & 7.50 \pm 0.20 & 100.00 \\ 10.0 & 9.62 \pm 0.60 & 96.20 \\ 15.0 & 14.20 \pm 0.20 & 94.67 \\ 20.0 & 20.50 \pm 5.10 & 102.50 \\ 25.0 & 25.90 \pm 8.88 & 103.60\end{array}$

$+n=3$

$a=\times 10^{7}$ 
page 141

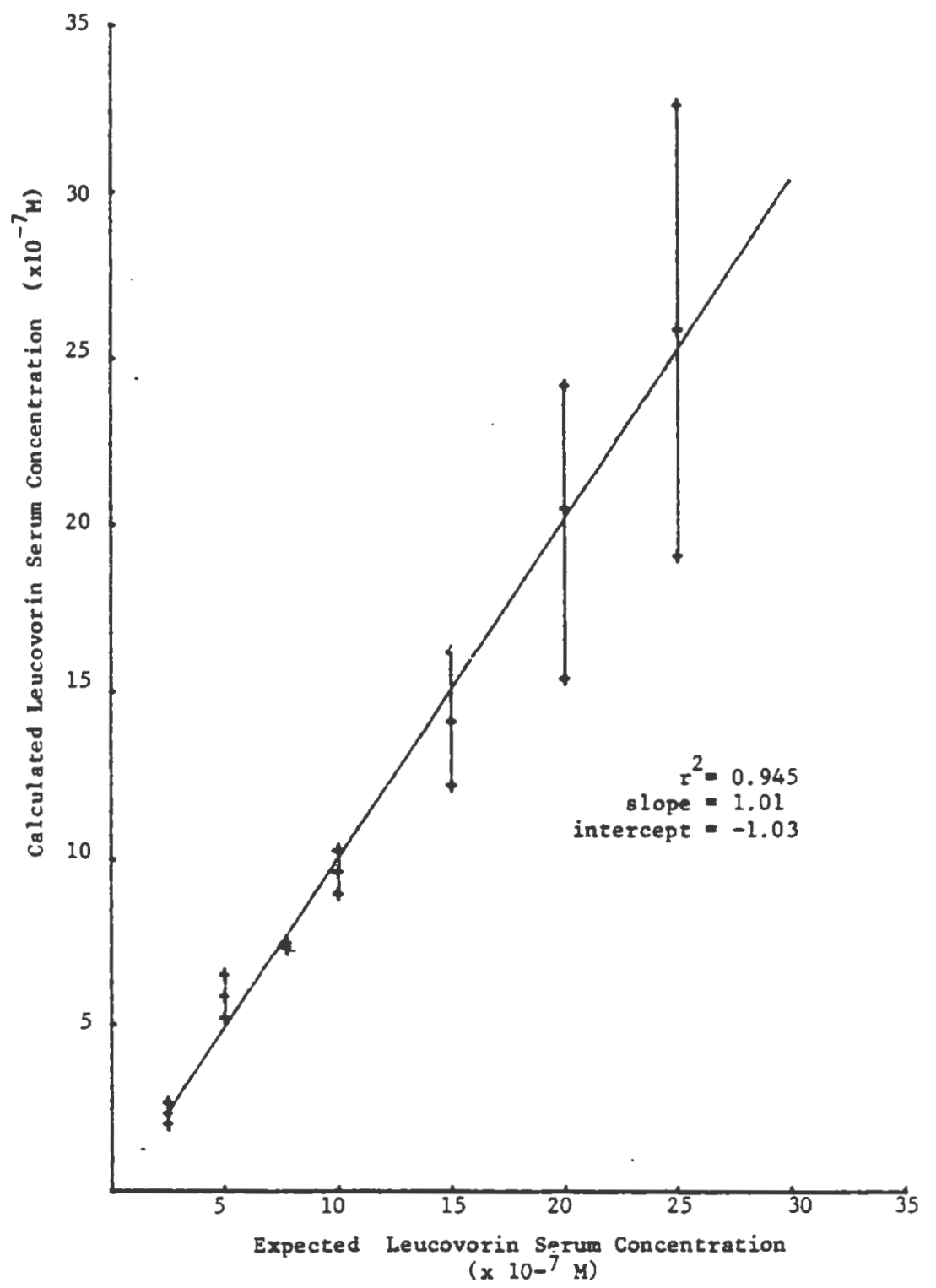

Figure 21: Leucovorin Recovery from Serum Observed vs Expected Leucovorin Concentration 
page 142

to analyze serun saples were calculated to be less than 5 percent.

\section{b. Sample stability}

The stability of IEl in the sampling dishes vas evaluated in order to determine the maxinum length of tine that samples could be stored in this condition.

Leucovorin was added to $20 \mathrm{~m}$. of pooled buman serun to yield a final concentration of $1.07 \times 10^{-6} \mathrm{E}_{\text {. Nine. } 1 \mathrm{~N}}$ seru. samples vere then extracted and evaporated as previously dercribed. The samples were randonly assigned to 3 groups of 3 samples each, which were then frozen until assayed. The first group was assayed the dap following extraction: the second. 2 days after extraction: and the third was assayed on the fifth day after extraction. The Iesults of these assays vere combined with the results of 3 assays performed innediately after the extraction process, and appear in Table VII.

The calculated IEO concentration following the extraction procedure was conpared with the LEU concentration in the serua samples prior to extraction. No statistical differences vere noted when samples vere assayed the same day. one day. or two days follouing the extraction procedure (Duncans unltiple Range test, p<0.05). However. when the samples were stored for 5 days, there was a significant decrease in the calculated IEO concentrations. Proe these data is was concluded that 
page 143

although analysis of seru samples following the extraction procedure need not be done imediately, two days was the maximu acceptable time between the extraction and analysis of IEJ serum samples. Serua samles from all cancer patients and all normal subjects were assayed the day of extraction or within 24 hours.

3. Separation of Leucororin in Serun

Pollowing the characterization of several of the important RCSS operating parameters, a mobile phase was dereloped wich effectirely separated IEO from the oxidizable, extracted seru componts (Table III).

Figure 22 shows representative chromatograms for LEU and METHF, wich vere obtained using the parameters detailed in Table VIII. The capacities, selectivity. resolution, and efficiency of the chromatographic syster is given in Table vII.

The capacities calculated for LEO and METBP fall in the range which is generally considered to be optinal. 1.e.. 2 to 10 .

Resolution is a means of measuring the degree of separation of any two conponents in a chromatogram and is usually definpd as the difference between the peak centers of two peaks, dirided by the arerage base width of the peaks (Equation 18).

$$
r=\left(v_{t}^{2}-v_{t}^{1}\right) / 0.5 *\left(w_{1}+w_{2}\right)
$$


TABLE VII

STABILITY OF FROZEN LEUCOVORIN EXTRACT

$\begin{array}{ccc}\text { Days } & \text { Initial Concentration } & \text { Calculated Concentration } \\ \text { Frozen } & \text { (Moles/Liter) } & \text { After Reconstitution*a } \\ & \text { (Mean } \pm \text { S.D.) }\end{array}$

0

1.00

$0.96 \pm 0.07$

1

1.07

$1.05 \pm 0.18$

2

1.07

$1.14 \pm 0.10$

5

1.07

$0.82+0.07$

$* \mathrm{n}=3$

$a=x 10^{6}$ 
page 145

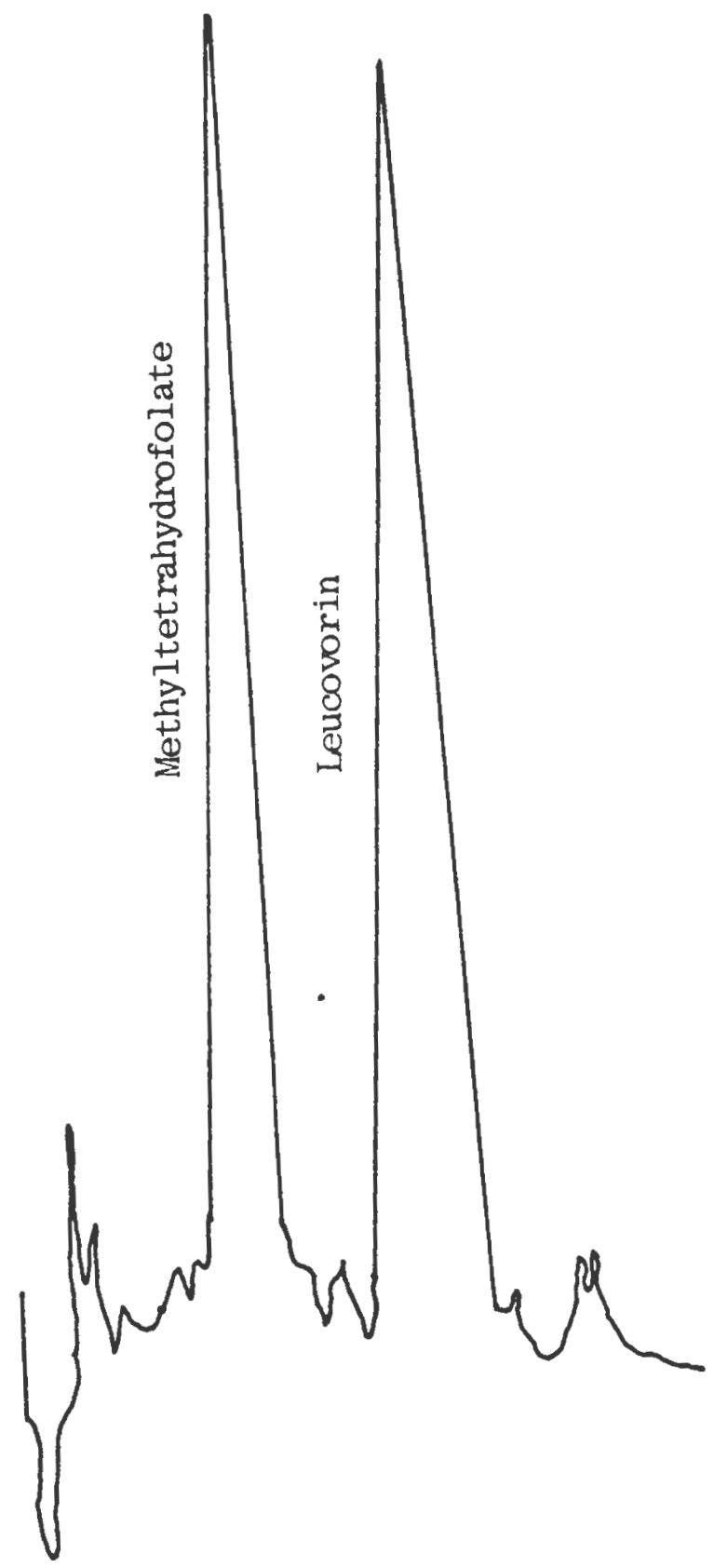

Figure 22: Separation of Leucovorin and Methyltetrahydrofolate Using Radially Compressed Colum 
TABLE VIII

CHROMATOGRAPHIC PARAMETERS DESCRIBING

THE SEPARATION OF LEUCOVORIN FROM

SERUM COMPONENTS

$\left(\mathrm{NH}_{4}\right)_{2} \mathrm{HPO}_{4}$

92.00

Me thanol

4.50

Acctonitrile

3.50

Sodium EDTA

$10.00 \mathrm{MM}$

$\mathrm{pH}$

3.50

Column: Radial Pak A

Elow Rate: $3.0 \mathrm{ml} / \mathrm{min}$

Column Temperature: $40^{\circ} \mathrm{C}$

Leucovorin Retention

8.05 Min.

Leucovorin Capacity ( $\left.\mathrm{K}^{\prime}\right)$

7.13

Resolution: (Leucovorin from the Closest Eluting Peak):

1.61

Colum Efficiency (Leucovorin):

530.00 Plates 
a resolution of 1.5 or greater indicates that two components are completely separated. The calculated resolution between the reduced folates was 2.07 indicating conplete baseline resolution of these components.

Efficiency is the measure of band spreading of a peak throughout a chronatographic peak. Bigh efficiencies generally produce sharper peaks than do low efficiency systens. The efficiency calculated for the reduced folates under the systen caployed in this work, is substantially lorer than the manufacturers clain for the system (5000 plates). Chronatography of folate compounds generally results in low efficiencies uhich can best be explained by the anphoteric nature of the compounds. Because the compounds ay exist in more than one ionic forn during the separation. the relative retentions will differ. The net result of this effect is band broadening. A second explanation is the use of high buffer concentrations uhich are necessary for optinan electrochemical detection, and nay adrersely effect resolution and hence efficiency (Rausch, 1980).

Figure 23 is a chronatogran obtained fron the injection of the reconstituted serun sample obtained from subject $\mathrm{KB}$ immediately before IEU adninistration. This chromatogran is representative of the 'serua-blank' obtained fron all nornal rolunteers and patients who received MTX. Several peaks were found to elute before 
page 148

LEU, and a single peak followed the drug. No additional peaks were observed wen similar chromatograms vere allowed to continue for 30 minutes. The serul peaks evident in Figure 23 were present in all samples chromatographed at approrimately the same anounts in all extracted serua samples. These peaks, which vero not identified, did not interfere with the quantification of LEO, although IETBF, was asked with the unknown peak having a retention time of 4.6 minutes (versus 4.37 minutes for HETHF)

Figure 24 shows the presence of LEO after adinistration of a $10 \mathrm{mg}$ - intravenous dose to subject $\mathrm{K} B$. This chromatogran was taken from the volunteers 6 hour serum sample. The resolution between $I E 0$ and the unidentified peak eluting at 6.12 minutes vas calculated from this chrowatogran. The resolution of 1.61 indicates complete resolution of LEU fron the closest unknown peak in extracted serua samples. When the resolution between these two peaks declined to 1.25 or less, the chromatographic colunn was regenerated or replaced as necessary. 
page 149

Pin

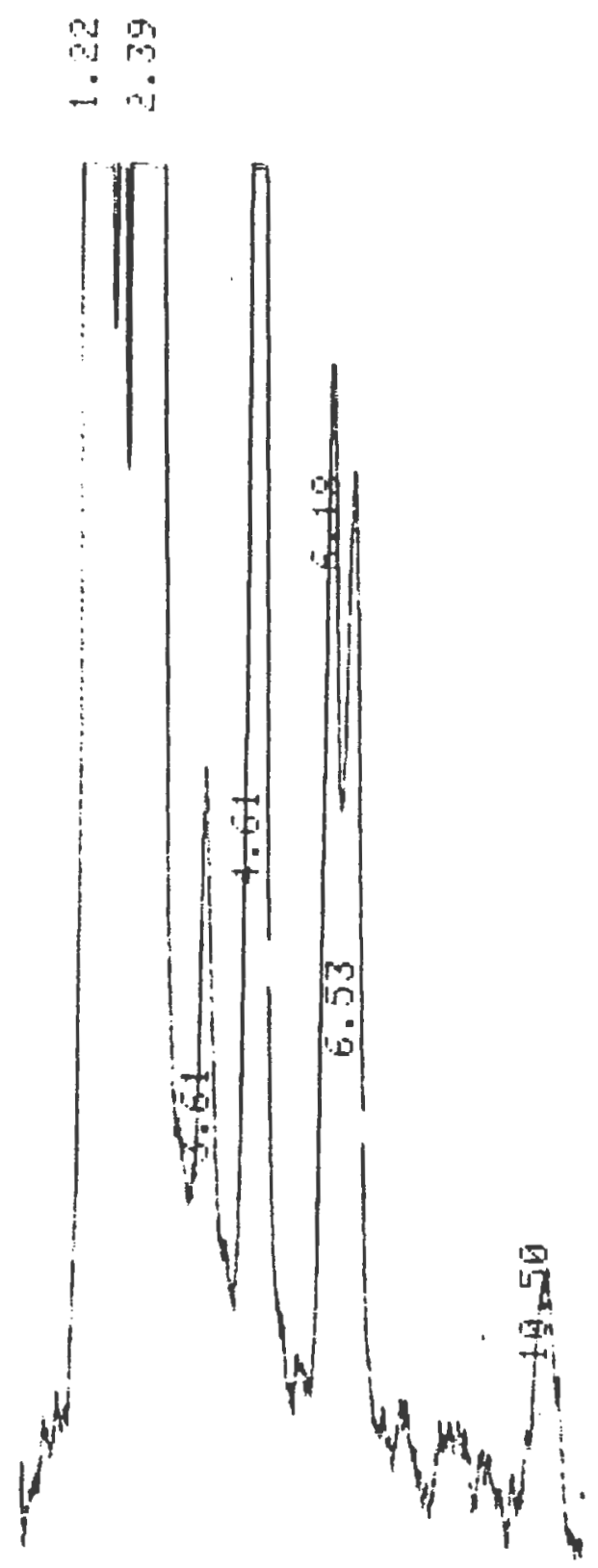

Figure 23: Serum Blank; Subject KB 
page 150

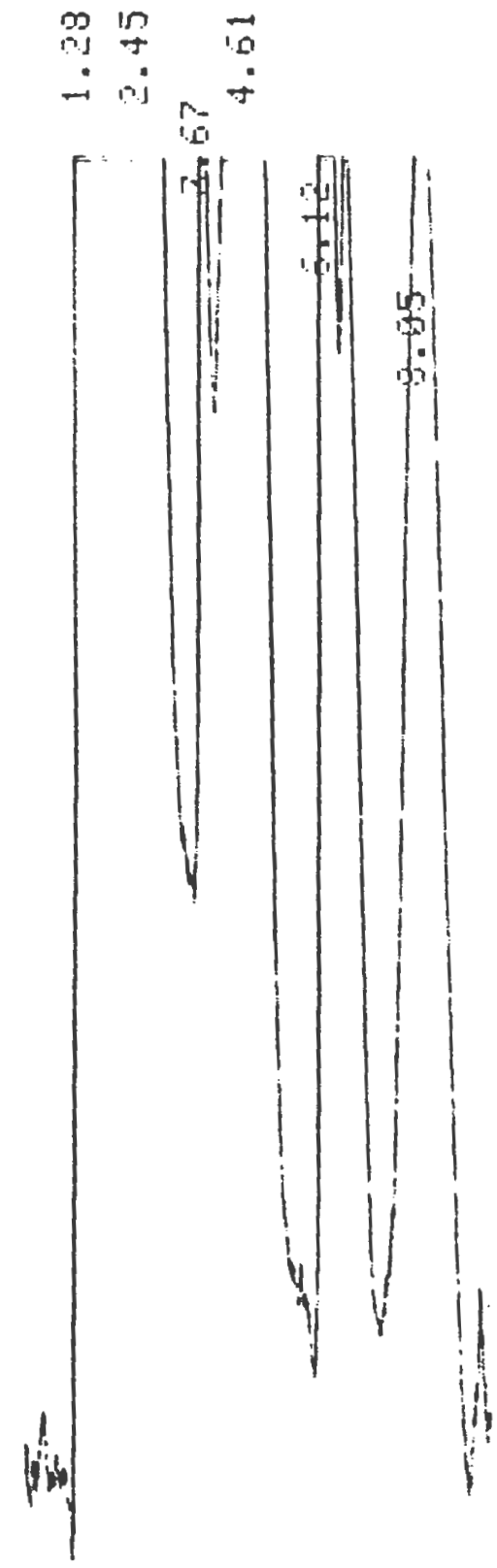

Figure 24: $\begin{aligned} & \text { Leucovorin in Serum; } \\ & \text { Subject } \mathrm{KB}\end{aligned}$ 


\section{Protein Binding}

1. Non-Specific Binding

Non-specific binding of either LEO or METHF to the components of the ultrafiltration cell or membrane was negligible. Filtered samples of the drug solutions showed no significant difference (student's t, p<0.05) when conpared to sanples taken from the ultrafiltration cell before being filtered.

2. Analysis of Albumin solution

Samples obtained from the direct altrafiltration of both dialyzed and non-dialyzed albuin were chromatographed. The samples obtained from the non-dialyzed albumin were shown to have a component or components which interfered with the quantification of both leacovorin and 5-methyl THP. The ajor interfering peak had a retention of 5.69 minutes ard produced an input signal greater than 2.0 volts. Chlorofora, toluol, and decanol. which may be used to induce crystallization of albunin, have heen inplicated as possible contaninants of connercially prepared albumin (Chignell, 1977). Dialysis of the albunin solution orernight at $4{ }^{\circ} \mathrm{C}$ against a large rolume of water or buffer has been suggested as a neans of romoring such contaninants (Chignell, 1977).

albumin used for the protein binding determinations was obtained from one source (Calbiochem Inc.. Palc Alto. 
page 152

CA.1. However, two different lots of albumin were received. Lot No. 600638, used for the first two leucovorin binding experinents, was not dialyzed and nothing in the filtrate interfered with the drug analysis. Praction V Human Serun Albumin Lot Yo. 903635, used for the Einal leucororin binding study produced sereral peaks which interfered with the chromatography of both leucovorin ard UETHF. Dialysis successfully remored the contaminant(s) and no difference in IEJ protein binding was observed using either dialyzed or non-dialyzed albunin.

Calbiochea Inc. confirmed (1980) that two different manuacturing processes had been used to prepare the tyo lots of albumin. Although the methods of preparation were not revealed, it seems likely that contaninant(s) such as those described by Chignell (1977) were present. The fact that dialysis of the protein solution readily remored the contaminants responsible for the interfering peaks is further evidence for this explanation.

\section{Leucovorin Protein Binding}

The protein binding of leucororin was deternined over a total drug concentration range of $5 \times 10^{7}$ to $1 \times 10^{-3} \mathrm{H}$. The lower limit of binding deteraination was governed by assay sensitivity. the upper linit by leucororin solubility.

Leucororin binding to human serum albumin is essentially constant, $69.95 \% \pm 4.70 \%$, orer the clinically significant concentration range. Figure 25 shows the 
page 153

percent of leucororin bound plotted as a function of total drug concentration. It is apparent fron this figure that saturatios of the protein had not occurred at the highest arug concentration examined. Horeover, binding did not decline appreciably witb increasing drug concentration.

The limited solubility of leucororin prevented the deteraination of binding at higher concentrations and also prevented the calculation of scatchard parameters for IEU. Figure 26 represents a scatchard plot for LED. a set of data is considered adeissible for scatchard analysis if it meets the criterion of having an "everywere negative slopen (Pletcher, 1973). The degree of scatter evident in Figure 26 prevents the conclusion that this condition has been net. Therefore, the scatchard nodel is not applicable for analysis of these data.

Values for affinity constants and numbers of binding sites can be estimated by steprise computer analysis using iteratire techniques (Fletcher, 1973). These technigues rely on reasonably accurate starting estimates, which are usually obtained by graphical methods. such estinates are not available either by scatchard, Scott, or klotz plots because of the scatter in the leucororin binding data and the limited range orer which binding was deternined.

4. Leucoforin Binding to Borine Albunin Albumin from various animal species can vary greatly in their drug binding characteristics (King, 1973). 
Page 154

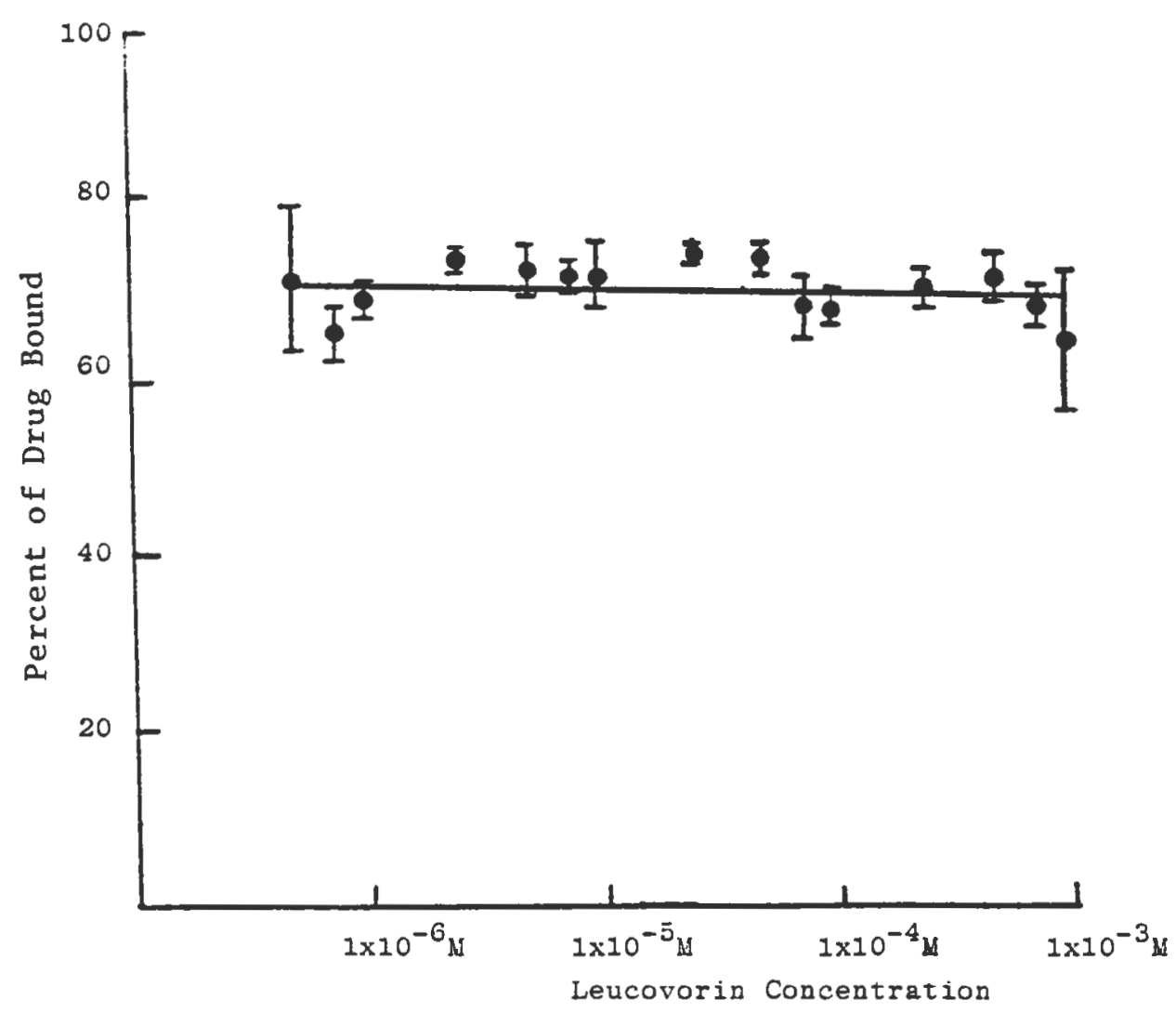

Figure 25: Percent of Leucovorin Bound to Human Serum Albumin as a Function of Concentration 


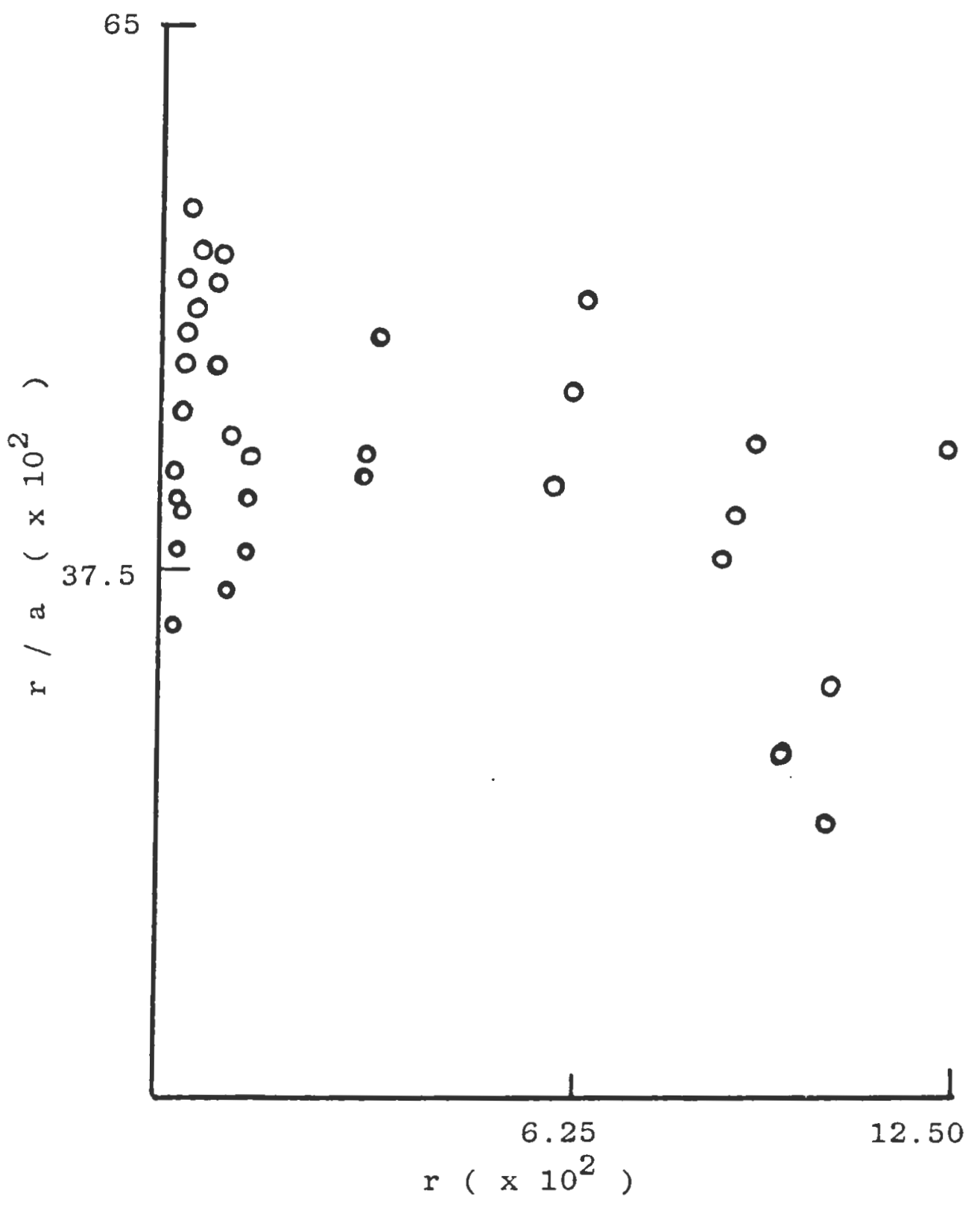

Figure 26: Scatchard plot for Leucovorin ( $r / a$ as a function of $r$ ) 
page 156

Leucovorin binding to four percent (w/w) bovine serum albumin was deternined over a drug concentration range of $2.5 \times 10^{-6}$ to $1.0 \times 10^{-4} \mathrm{H}$. Figure 27 . The binding was constant over the range studied $(69.37 \% \pm 8.67)$ as was the case vith buman serun albumin. A two way arora was performed on these data, and it showed that no significant difference $(p<0.05)$ existed between leucovorin binding to the two types of albunin.

\section{LETHF Protein Binding}

METHF protein binding was determined over the drug concentration range of $5 \times 10^{-1}$ to $1 \times 10^{-3}$. The binding of METF, unlike leucororin, did not remain constant. Figure 28 is a plot of percent drug bound as a function of total drug concentration. While saturation of the protein does not appear to have been reached, it is clear that the percent of drug bound to albumin decreased appreciably with increasing concentration. At $5 \times 10^{-7} \mathrm{~B}, 86.24 \%$ of the drug was bound, at $1 \times 10^{-3}$ binding had decreased to $64.11 \%$. In other vords, the percent of free drug had increased 2.5 tines orer this concentration range.

Figure 29 is a scatchard plot for METHF. As with leucovorin, the scatter in the data makes it impossible to assume that the criterion of an "everyubere negative slope" has been met. These data cannot be described in terms of a Scatchard nodel. voreover, graphical techniques cannot yield reliable first estimates of $\mathrm{Ka}^{\prime} \mathrm{s}$ or $\mathrm{n}^{\prime} \mathrm{s}$, and no final 


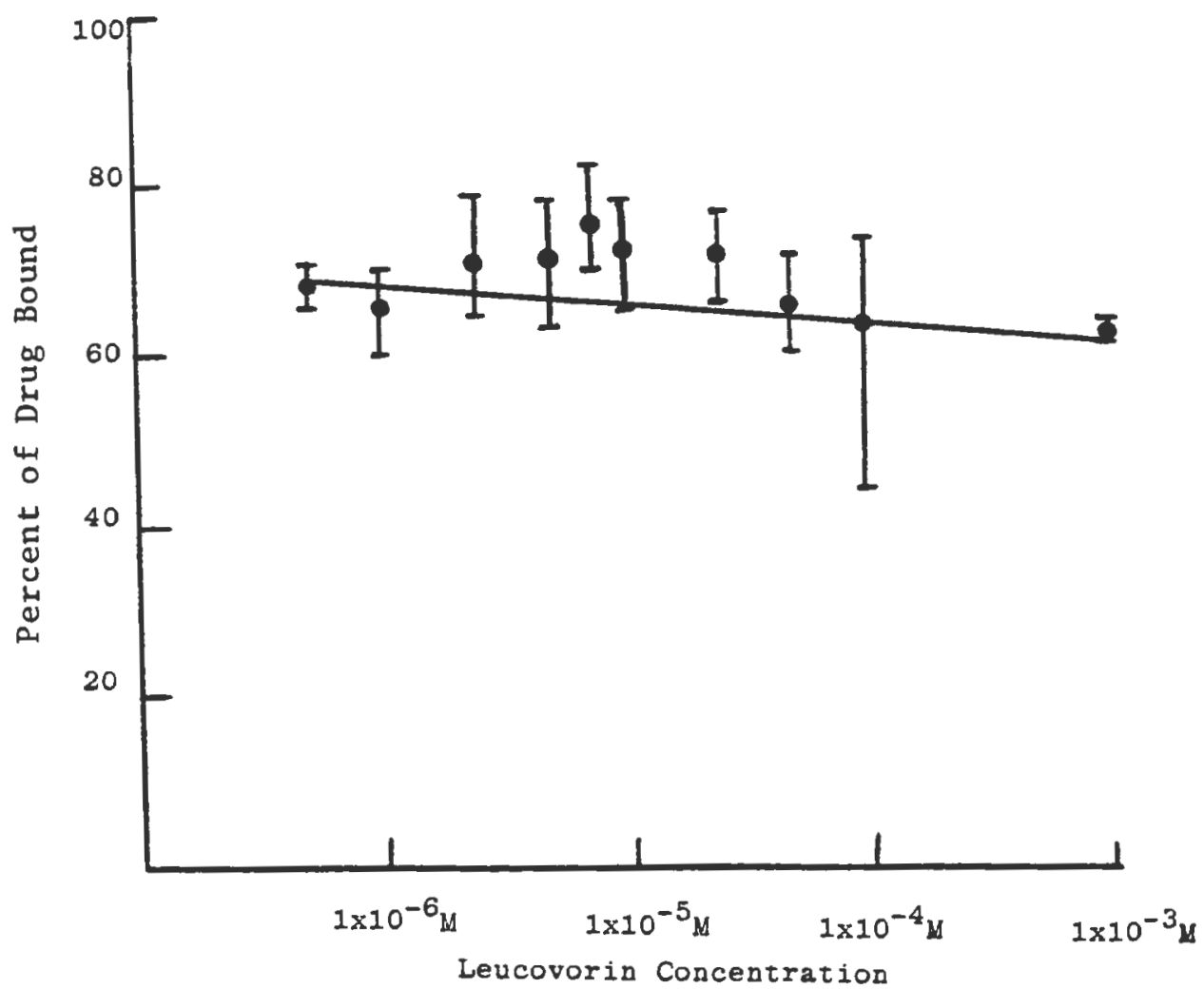

Figure 27: Percent of Leucovorin Bound to Bovine Serum Albumin as a Function of Concentration 


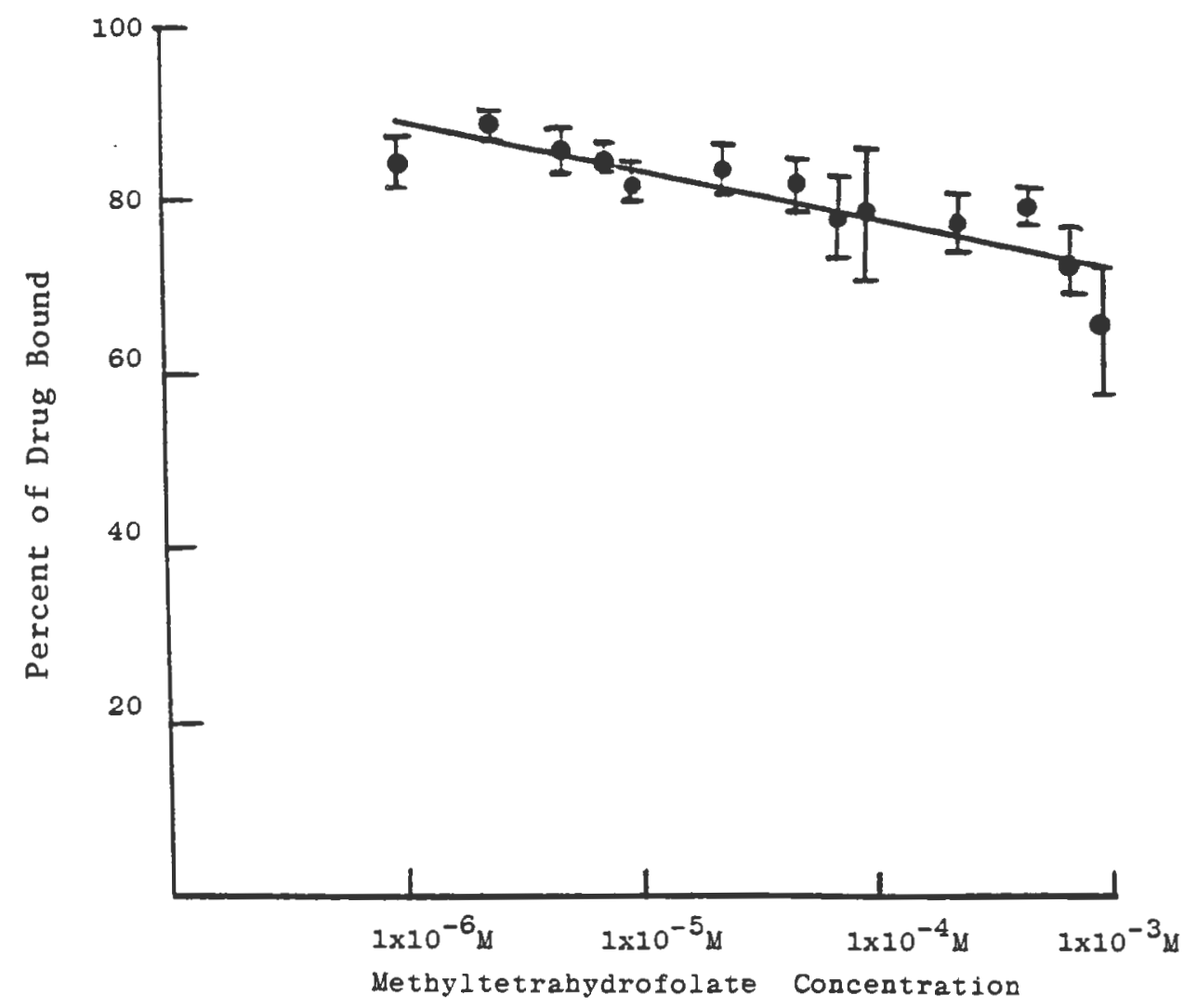

Figure 28: Percent of Methyl tetrahydrofolate Bound to Human Serum Albumin as a Function of Concentration 


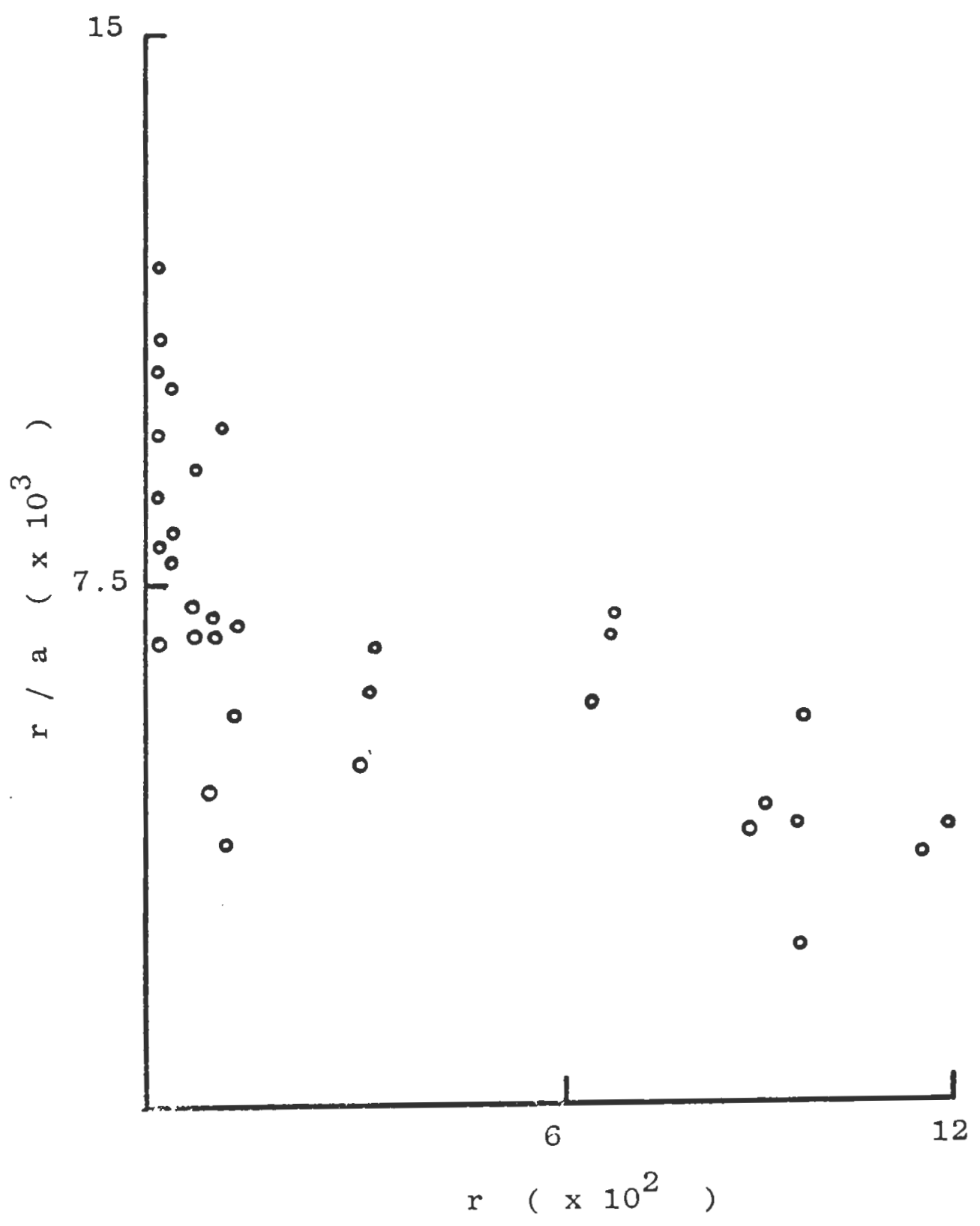

Figure 29: Scatchard Plot (r/a vs. $r$ ) for Methyl tetrahydrofolate 
values for affinity constants or numbers of binding sites can be obtained.

\section{LEO, METHP Protein Binding Interactions}

Since IEU and HETAP coerist in plasma, there is the possibility of competition for a common binding site, which nay alter the binding characteristics of one or both drugs. To investigate this potential interaction, the two drugs vere ultrafiltered together and the protein binding deternined. Four conbinations of drug concentrations were evaluated: Eirst, equinolar concentrations of IEO and uETHF $\left(5 \times 10^{-5} \quad\right.$ and $5 \times 10^{-6}$ H) : in addition, LEO was prepared in excess of HETHF $\left(5 \times 10^{-5}\right.$ and $5 \times 10^{-} \quad 4$. Iespectively): the concentrations vere then reversed so that METHP was in excess.

The effect of uethr on the binding of IEO is shown in Table Ix. The decrease in LED binding in combination with UETHF was significant at all levels tested (two way MNOVA, p<0.051- The greatest change ocurred with METHF present in ten fold excess of IED. The percent of IEO bound to albumin decreased from a mean value of $72.49 \% \pm 2.62 \%$ to a mean of $31.36 \% \pm 4.94 \%$.

The same result was obtained wen the effect of IEU on the binding of METHF was examined. A significant decrease in aETHF binding is observed witb all combinations of LEU, Table IX. The greatest decline in binding, approximately 20. is observed when both drugs are conbined at $5 \times 10^{-5} \mathrm{M}$. 
page 161

in comparison to HETHF alone at this concentration.

The study of the protein binding interactions between IEU and Metrif yields several conclusions. First, it is apparent that, since the degree of binding decreases for both drugs wher they are present simultaneously. IEd and UETHF appear to share a comon binding site (or sites). secondly. since METHP binding is influenced to a lesser degree by LED than is LEO by METHF, it is reasonable to conclude that uETHF has a stronger affinity for the site than does IEO. Finally, it is erident that deternining the protein binding of any of the reduced folates for folir. acid) alone ing_ritzo does not reflect the physiological state in which folates exist. The differences in the degree of folate binding reported in the literature. particularly with respect to folic acid. way be attributable to the presence (or absence) of other folate forms at the time of assay. as vell as to the method used to determine binding. 


\begin{abstract}
TABLE IX
LEUCOVORIN - 5-METHYL THF

PROTEIN-BINDING INTERACTIONS
\end{abstract}

LEU

CONCENTRATION

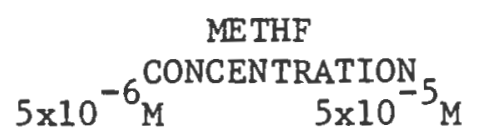

$$
\text { (\% BOUND } \pm \text { S.D. })
$$

$85.45 \pm 2.0081 .13 \pm 2.42$

$66.04 \pm 1.6471 .68 \pm 3.86$

$67.72 \pm 4.9060 .58 \pm 2.75$

$$
\begin{aligned}
& 5 \times 10^{-6} \mathrm{M} \\
& 5 \times 10^{-5} \mathrm{M}
\end{aligned}
$$


TABLE X

LEUCOVORIN - 5-METHYL THF

PROTE IN-BINDING INTERACTIONS

5-METHF THF
CONCENTRATION

LEU
CONCENTRATION

CONCENTRATION $5 \times 10^{-6} \mathrm{M} \quad 5 \times 10^{-5} \mathrm{M}$

$(\%$ BOUND \pm S.D. $)$

0

$72.49 \pm 2.6273 .83 \pm 1.43$

$5 \times 10^{-6} \mathrm{M}$

$42.53 \pm 4.19 \quad 64.74 \pm 4.46$

$5 \times 10^{-5} \mathrm{M}$

$31.36 \pm 4.94 \quad 50.75 \pm 1.81$ 
page 164

\section{LEO and BETHF ETX Binding Interactions}

Leucororin is clinically adeinistered to patients following the infusion of atx. Current protocols at Roger Dilliams General Hospital, require that the IEU administered result in a plasma concentration ten times higher than the corresponding Mr concentration. To deternine the effect of uTX on the binding of IEU the two were ultrafiltered simultaneously using two combinations of arug. In each case lEo was present in ten fold excess: first at $1 \times 10^{-6}$ in the presence of $1 \times 10^{-1}$. then at

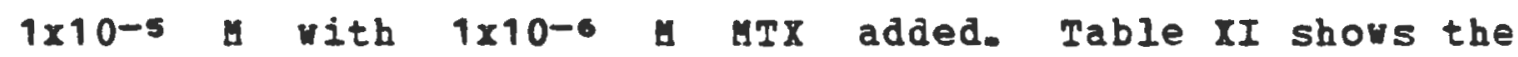
effect of UTX on the binding of LED. No significant difference ( $t$ test. $p<0.05$ ) was observed in IEO binding with MTX.

Since METHF is the predoninant circulating folate the interaction with MI vas also deternined. The same schene of concentrations as described above was used. The effect of methotrexate on the binding of neTHF is shown in Table XII. The degree of EETHF binding at $1 \times 10^{-5}$ a did not change significantly (t test, $p<0.05$ ) in combination with aTX.

Hethotrerate had a significant effect (t test, $p<0.05$ ) on the binding of ETHF with concentrations of $1 \times 10^{-7}$ and 1×10-6. Iespectively. Howerer, Iather than displacing HETHF fron a binding site, thereby decreasing the extent of binding. the binding actually increased. The increase in binding was from $84.20 \% \pm 2.67 \%$ to $97.19 \% \pm 2.11$, which is 
TABLE XI

LEUCOVORIN

PROTEIN-BINDING INTERACTIONS

WITH METHOTREXATE

\begin{tabular}{|c|c|c|}
\hline $\begin{array}{c}\text { MTX } \\
\text { CONCENTRATION }\end{array}$ & $\begin{array}{r}I \\
\text { CONCEI }\end{array}$ & URATION \\
\hline & $1 \times 10^{-6} \mathrm{M}$ & $1 \times 10^{-5} \mathrm{M}$ \\
\hline & (\% BOUI & \pm S.D. ) \\
\hline 0 & $68.44 \pm 0.72$ & $71.94 \pm 3.54$ \\
\hline $1 \times 10^{-6} \mathrm{M}$ & $-\cdots-\cdots$ & $66.85 \pm 1.50$ \\
\hline $1 \times 10^{-7} \mathrm{M}$ & $69.23+3.95$ & - \\
\hline
\end{tabular}


Page 166

TABLE XII

METHF

PROTEIN-BINDING INTERACTIONS

WITH METHOTREXATE

\begin{tabular}{|c|c|c|}
\hline $\begin{array}{c}\text { MTX } \\
\text { CONCENTRATION }\end{array}$ & $\begin{array}{r}\text { ME I } \\
\text { CONCENT }\end{array}$ & $\begin{array}{l}\text { HF } \\
\text { RATION }\end{array}$ \\
\hline & $1 \times 10^{-6} \mathrm{M}$ & $1 \times 10^{-5 M}$ \\
\hline & (\% BOUn & $D \pm$ S.D.) \\
\hline 0 & $84.20+2.68$ & $81.00+1.71$ \\
\hline $1 \times 10^{-6} \mathrm{M}$ & --ー- - & $78.73 \pm 3.89$ \\
\hline $1 \times 10^{-7} \mathrm{M}$ & $97.19 \pm 2.11$ & - - - \\
\hline
\end{tabular}

*Significant at 0.05 Level 
page 167

highly significant. An increase in the percent bound under these conditions is unexpected and cannot be readil: explained. The increase may be the result of assay error since the deterninations of free concentrations of METHF with total concentrations of 5x10-7M requires measuring between $1 \times 10^{-7} \mathrm{M}$ and $5 \times 10^{-6}$, the lover linit of detection.

These results indicate that, since no differences in binding vere found. HI does not share a binding site with LEO. The same conclusion can be reached for HETHF even though the degree of binding ras signficantly increased in the presence of $M T X$ at one concentration. If a binding site vere shared, the degree of binding ight logically be expected to decrease, not increase as vas the case. Moreover, the binding of METHF did not change vith MTX at higher concentration. It is therefore unlikely that uIx and METHF share a comon binding site.

\section{E. IEO Pharmacokinetics}

1. Nornal subjects

The disposition of intravenously administered LEU has been characterized in 6 healthy volunteers: 3 males and 3 fenales. Figures 30 and 31 shor the serum clearance of the drug following the administration of $10 \mathrm{mg}$, to the male and female subjects respectively. In both groups the disappearance of LE was characterized by an initial rapid distribution phase folloved by a considerably slover elimination phase. 


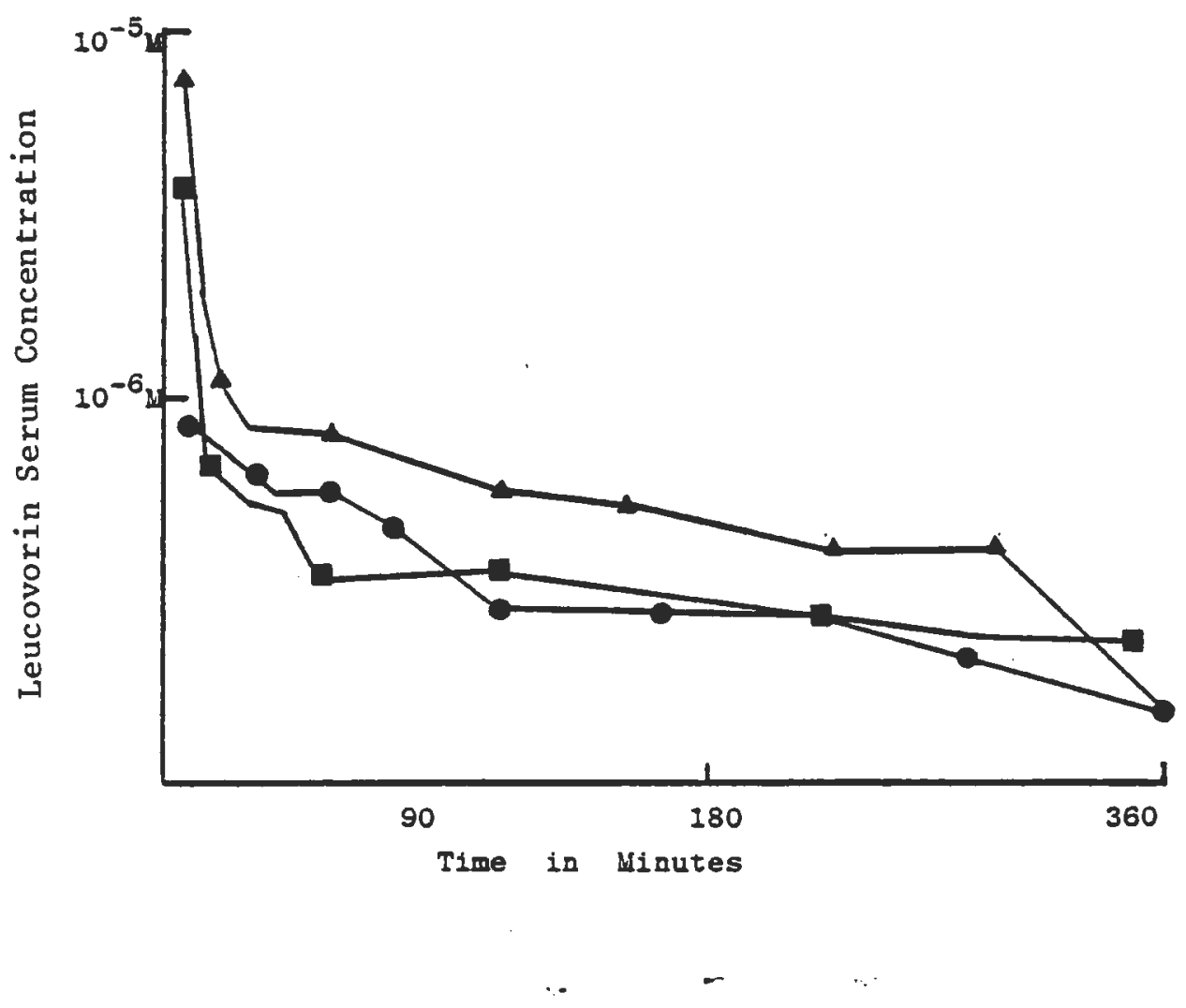

Figure 30: Leucovorin Serum Concentration as a Function of Time; Normal Males

$$
\text { D- } \mathrm{EM}, \quad \mathrm{O}=\mathrm{BB}, \quad \square=\mathrm{KM}
$$


Page 169

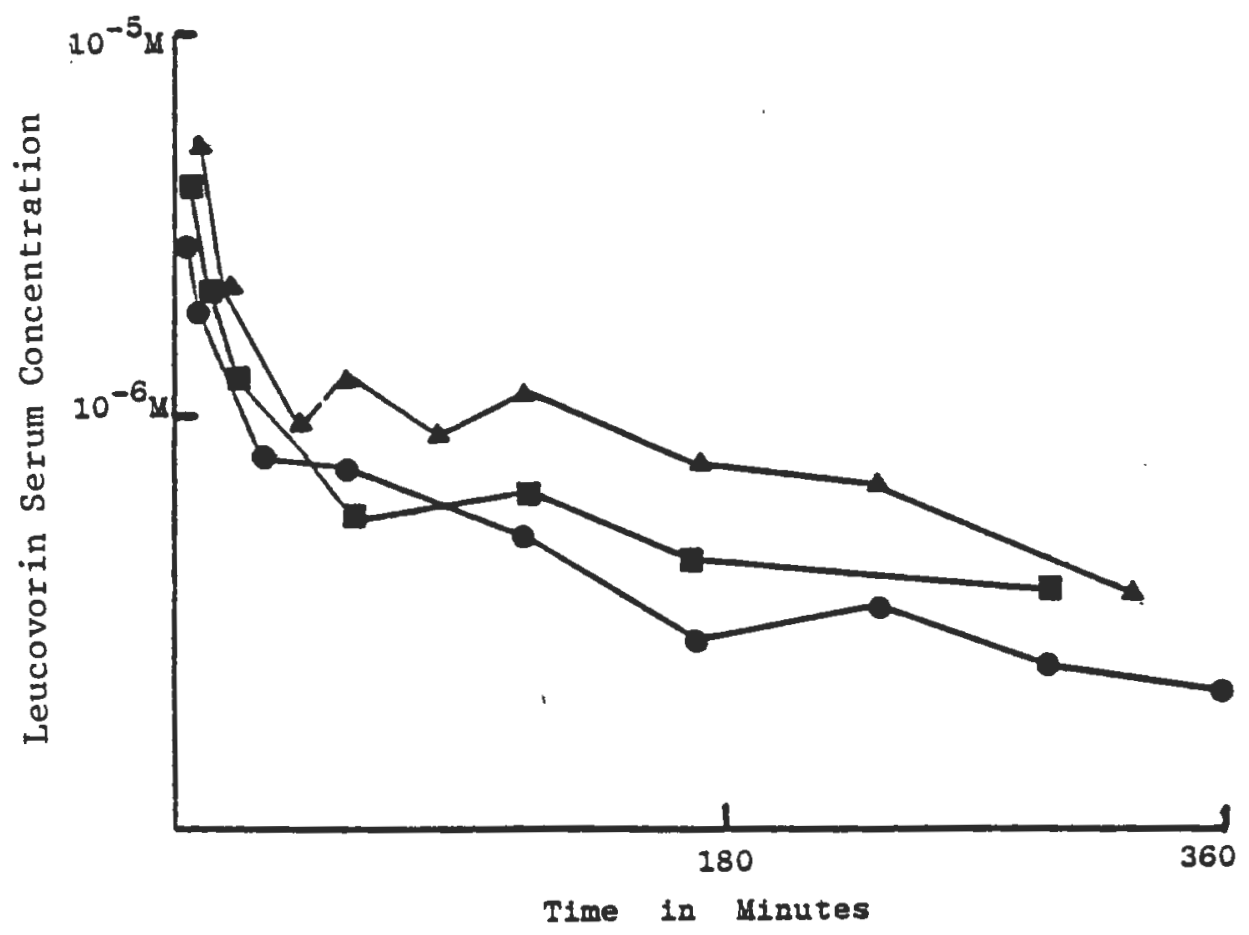

Figure 31: Leucovorin Serum Concentration as a Function of Time; Normal Females
$\Delta=L G$,
$D=G M$,
$=L B$ 
page 170

LEO data for the serua concentration as a function of time was first analyzed using an ITEL AS/5 Computer systen and a decision-making pharmacokinetic computer program: AOTOAN (Sedman and Nagner, 1974). This program assunes a first order elinination rate constant and exanines the fit of a one, two, or three compartment open model to the data. The numer of terms in the polyexponential equation is deternined, an appropriate model is selected, and the microscopic rate constants, and rolume of distribution are estimated. (Sedman and nagner, 1974). The serum data for the concentration as a function of time for all 6 subjects was deternined to be best described by a two compartment open model with elimination occuring solely from the central compartment (Figure 32). The biexponential equation which describes the plasma concentration as a function of time is:

$$
C p=A e^{-\alpha t}+B e^{-\beta t}
$$

(Equation 19)

Where $A$ and $B$ are pre-exponentiaj. terms and alpha and beta represent the rate constants for distribution and elimation respectively (Curry. 1974).

These values may also be expressed in terms of the micro-constants k12, kel, and k21. These expressions as well as their derivations have been describea in detail (Gibaldi and Perrier. 1975). 
page 171
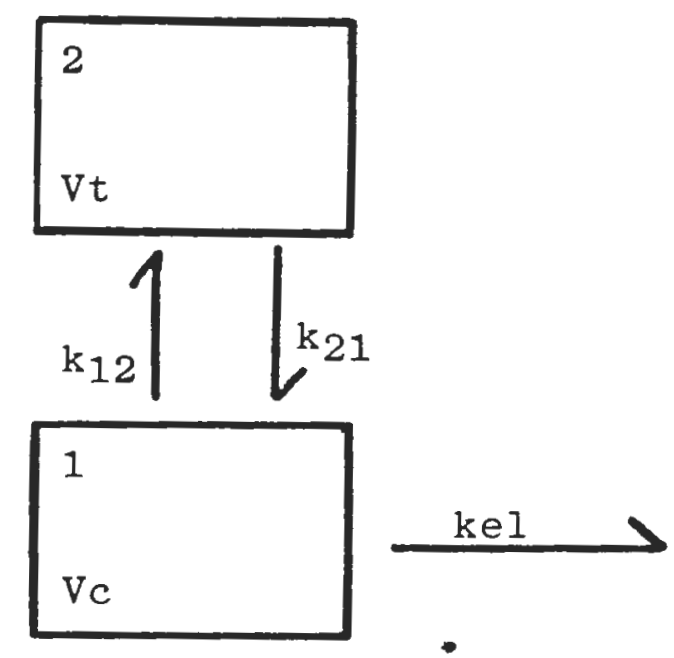

Figure 32: Two Compartment Open-Model 
page 172

The initial estimates provided by nOTOAN vere further Iefined using a second computer program, MOHLIN (HetzleI. Elfring, and McEwan, 1974)- The pharmacokinetic model, in this case the two comparment open-model, is specified and those values of the pertinent parameters are chosen wich give the best fit of the experimental data to the model. The fitting process vich is employed in roNLIy is an iteretive technique using non-linear least squares regression (Hetzler, Elfrin, and DCEwan, 1974). Pour weight specifications for the concentration function vere evaluated: the weighting schere which provided the best fit of the model to the data was used to obtain the final values of the pharnacokinetic paraneters. In addition, a subroutine program, DFUNC, was uritten to provide the necessary equations to fit the data was witten and appears in Appendix IV.

The pharmacokinetic parameters describing the dispositiion of intravenously adninistered IEU in all six subjects are given in Table IV. Although the aicroconstants have relatirely small standard deriations associated with them, the rolumes of distribution shov a great deal of variability. This can most likely be attributed to the large difference in the weights of the normal rolunteers, e.g. $45 \mathrm{~kg}$ to $100 \mathrm{~kg}$. Because the helght of the 6 subjects also raried greatly lover a $31 \mathrm{~cm}$. range) the surface areas calculated for the volunteers shoved a related variability: $1.37 \mathrm{~m}^{2}$ to $2.28 \mathrm{~m}^{2}$. 
TABLE XIII

LEUCOVORIN

PHARMACOKINETIC PARAMETERS CALCULATED

FROM NORMAL VOLUNTEERS

Parameter

\begin{tabular}{|c|c|c|c|c|}
\hline \multicolumn{2}{|c|}{ Parameter } & \multicolumn{3}{|c|}{$\begin{array}{l}\text { All Volunteers } \\
\text { (Mean } \pm \text { S.D. })\end{array}$} \\
\hline $\operatorname{Kel}{ }^{a}$ & Min. - 1 & 1.54 & \pm & 0.88 \\
\hline $\mathrm{K} 12^{\mathrm{a}}$ & Min. - 1 & 0.93 & \pm & 0.29 \\
\hline $\mathrm{K} 21^{\mathrm{a}}$ & Min. - 1 & 1.96 & \pm & 0.50 \\
\hline Vcl & ml ᄎMin. - 1 & 6.21 & \pm & 0.21 \\
\hline Vd (Cen.) & Liters & 5.49 & \pm & 3.53 \\
\hline Vd (ss) & Liters & 8.44 & \pm & 5.73 \\
\hline Vd (Beta) & Liters & 21.12 & \pm & 8.95 \\
\hline Vd (Extrap) & Liters & 24.10 & \pm & 9.39 \\
\hline Vd (Tiss) & Liters & 2.95 & \pm & 2.23 \\
\hline $\begin{array}{l}\text { Half-Life } \\
\text { (Alpha) }\end{array}$ & Minute & 8.79 & \pm & 4.44 \\
\hline $\begin{array}{l}\text { Half-Life } \\
\text { (Beta) }\end{array}$ & Minute & 231.46 & \pm & 31.76 \\
\hline
\end{tabular}

Mean $\pm S D, \quad(n=3)$

$a=x 10^{2}$ 
page 174

Mormalizing the volumes of distribution by expressing these terms as either $1 \mathrm{Kg}^{-2}$ or $\mathrm{I} \mathrm{m}^{-2}$ Iather than as $\mathbf{l}^{-2}$ greatly reduces the effects of subject variability in these parameters.

The description of a biexponential decay in LEO serun concentration as a function of time is in agreenent with the report of Rothenberg et ale (1979) in which a "rapidn decline was followed by a second prolonged elimination phase wich approaches a "plateau" in appearance. A similar rapid distribution phase lalpha half-life $8.79 \pm$ 4.44 minutes) and a "slow elinination phase ( beta half-life $231.46 \pm 31.76$ minutes) have been characterized in the present study. Rothenberg et $\underline{\text { al }}$ = (1979) have suggested that the platea results fron the selective elimination or tissue uptake of orly the active form of IEO, leaving the inactive diastereoisomer in the systemic circulation for prolonged periods. The present rork can neither confirm or refute such a suggestion since the assay method does not distinguish between forms of folinic acid. nor was the active diastereoisoner available for administration to the subjects. The total body clearance of the drag was calculated as 62.1 nin-1 $\pm 21.3 \mathrm{nl}$ min-1. Clearance has been calculated according to the following equation :

$$
\mathrm{V}_{\mathrm{cl}}=\beta * \mathrm{Vd}_{\beta}
$$


page 175

The large standard deviation evident in this parameter is nost likely caused by the previonsly. described rariability in rolumes of distribution.

Iiterature values reported for the percent of IEO excreted unchanged ay be used to approximate the renal and netabolic clearance of IEJ. spray and Vitts (1953) reported that an arerage of $15 \%$ of the adninistered drug was excreted in the urine in two hours. Rothenberg et al. (1979) calculated a value of approxinately $18 \%$ for the amount excreted nnchanged. In arerage value obtained fron these two reports, 16.5. was used to estinate a renal and a netabolic clearance for IEU. The total body clearance for LEO (FCl) was calculated to be an arerage of $62 \mathrm{ml} \mathrm{min}^{-2}$. The renal excretion can be calculated according to Equation 21:

$$
\mathrm{Cl}_{(\text {renal })}=\mathrm{GFR}+\mathrm{AS}-\mathrm{TR}
$$

(Equation 21)

The renal clearance of LEO was calculated to be $10.23 \mathrm{ml}$ nin-2. Subtracting this ralue frov ral fields the netabolic clearance: 51.77 nin-1.

The 6 nornal subjects vere assumed to have a nornal glonerular filtration rate of 120 al win- only the free. non-protein bound. fraction of circulating drug is subject to glomerular filtration. 
page 176

LEO. The contribution of glomerular filtration for LEO, assuming the fraction free to be $30 \%$ was calculated as 36 min-2. Since IEU's calculated renal clearance. 10.23 il min-2, is less thar the calculated maximu glomerular filtration rate, there is assuned to be tubular reabsorption of LED. The extent of reabsorption can be obtained from the difference between glomerular filtration and renal clearance. The net tubular reabsorption rate for LEO was calculated to be approxinately 26 m min-1.

A conparison of the pharmacokinetic parameters derived from the male and female volunteers is presented in Table 3. No statistical differences ( $P$ <0.05) vere observed in any of the pharmacokinetic parameters calculated.

\section{Cancer Patients}

The disposition of IEO was folloved in 4 patients undergoing High-Dose ETX therapy at Roger Dilliams General Bospital. One patient. I. H.. received 2 courses of treatment approximately 1 month apart and LE disposition was characterized following both courses. Three patients received the drug intravenously, the fourth was given IED by intramuscular injection.

In 3 of the data sets the diappearance of IEU following intravenous administration was characterized by an initial rapid distributive phase followed by a slower elinination phase. Figures 33 and 34 show the clearance of the drug in patient F.F and I. M. The biexponential decay 
page 177

was in agreement with the pattern observed in normal subjects. The seru. concentration-time data for these patients vas analyzed first using AOTOAN then NoNLIN to provide the final values of all parameters. Table $X \nabla$ shows the values of the pharmacokinetic paraneters derived from the cancer patients and normal male subjects. No statistical differences ( $p$ <.05) were found between parameter estimates in the normal subjects versus cancer patients.

lacking pharmacokinetic parameters for IED, the rescue protocol at Roger Dilliams General Bospital was dereloped assuming that its disposition is sinilar to that of ET. Leucororin rescue has been dosed to provide an initial plasma concentration ten-fold higher than the projected MTX concentration in the patient 30 hours after the termination of the atX infusion. Table XVI is a comparison of the expected LEO seru concentration and the calculated initial serun concentration determined by electrochenical assay. The calculated seru concentration averaged 6.67 times (range 3.5 to 11.8 ) greater than the expected concentration. Although the excess IRO will not result in toxicity. the net effect is to reduce the effectiveness of MrI therapy. The disparity between observed and expected serue concertrations may be largely attributed to the differences in volume of distribution between IEO and MTX. Table XVII shows a comparison of the half-lives and rolumes 
TABLE XIV

A COMPARISON OF

LEUCOVORIN

PHARMACOKINETIC PARAMETERS CALCULATED

FROM FEMALES VS. MALES*

\begin{tabular}{|c|c|c|c|c|c|c|c|}
\hline \multicolumn{2}{|c|}{ Parameter } & \multicolumn{3}{|c|}{$\begin{array}{c}\text { Males } \\
(\text { Mean } \pm \text { S.D. })\end{array}$} & \multicolumn{3}{|c|}{$\begin{array}{l}\text { Females } \\
(\text { Mean } \pm \text { S.D. ) }\end{array}$} \\
\hline $\operatorname{Ke} 1^{a}$ & Min. -1 & 1.14 & \pm & 0.43 & 1.93 & \pm & 0.11 \\
\hline $\mathrm{K} 12^{\mathrm{a}}$ & Min. -1 & 1.12 & \pm & 0.23 & 7.33 & \pm & 0.20 \\
\hline $\mathrm{K} 21^{\mathrm{a}}$ & Min. -1 & 2.25 & \pm & 0.49 & 1.68 & \pm & 0.39 \\
\hline Vd (Cen.) & Liter & 7.41 & \pm & 3.48 & 3.58 & \pm & 2.85 \\
\hline Vd (SS) & Liter & 11.31 & \pm & 5.62 & 5.51 & \pm & 5.08 \\
\hline Vd (Beta) & Liter & 26.40 & \pm & 9.24 & 15.97 & \pm & 5.77 \\
\hline Vd (Ext.) & Liter & 29.23 & \pm & 9.78 & 18.97 & \pm & 6.76 \\
\hline $\operatorname{Vcl}{ }^{a}$ & Ml/Min. & 7.49 & \pm & 1.94 & 4.94 & \pm & 1.64 \\
\hline Vd (Tiss) & Liter & 3.90 & \pm & 2.16 & 2.00 & \pm & 2.26 \\
\hline$t 1 / 2$ & Min. & 8.66 & \pm & 2.98 & 8.93 & \pm & 6.36 \\
\hline$t 1 / 2$ & Min. & 240.48 & \pm & 44.03 & 222.43 & \pm & 18.41 \\
\hline
\end{tabular}

*No Statistical Differences $(p<0.05)$

$a=\times 10^{2}$ 


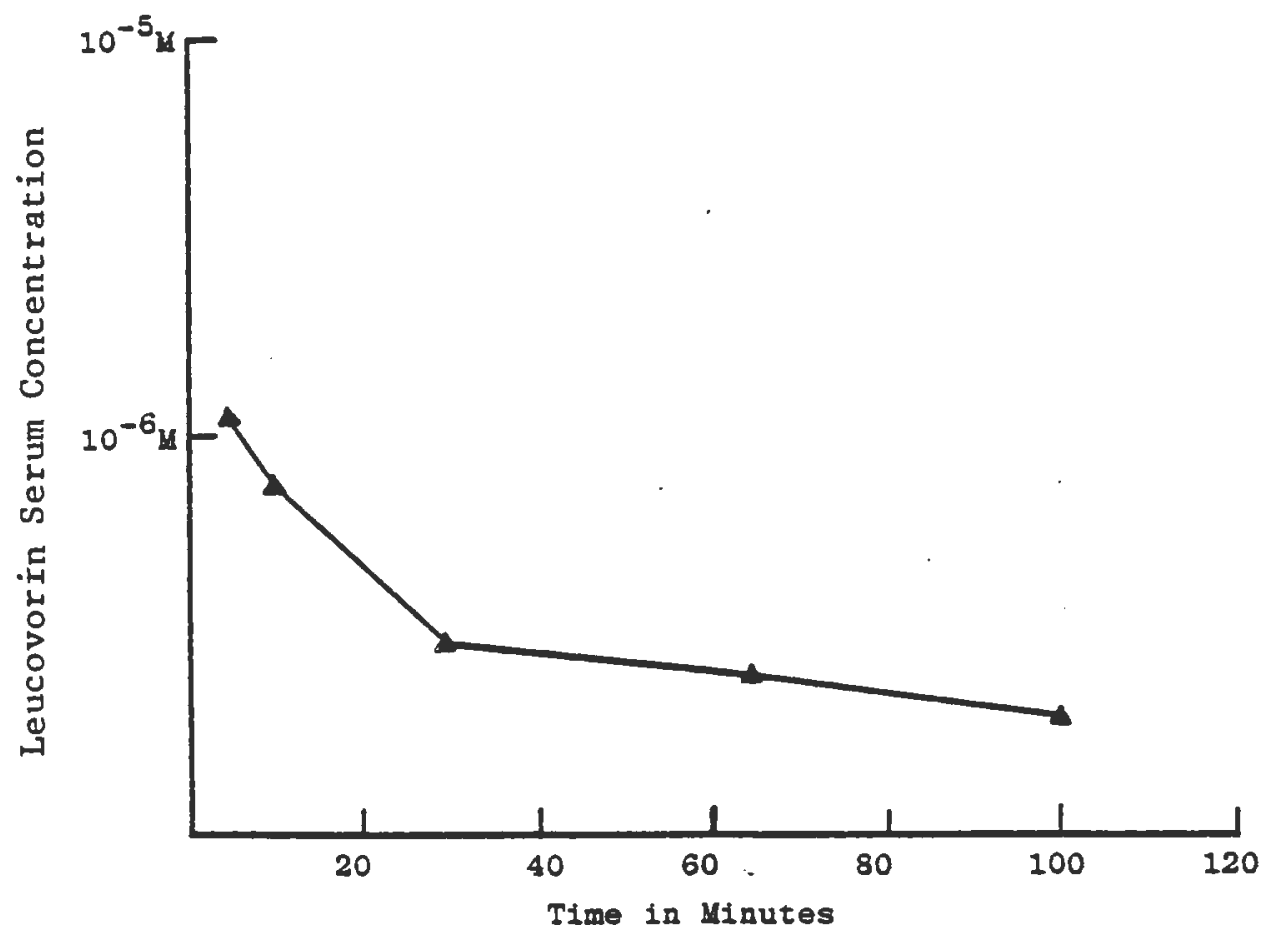

Figure 33: Leucovorin Serum Concentration as a Function of Time; Patient F.F. 


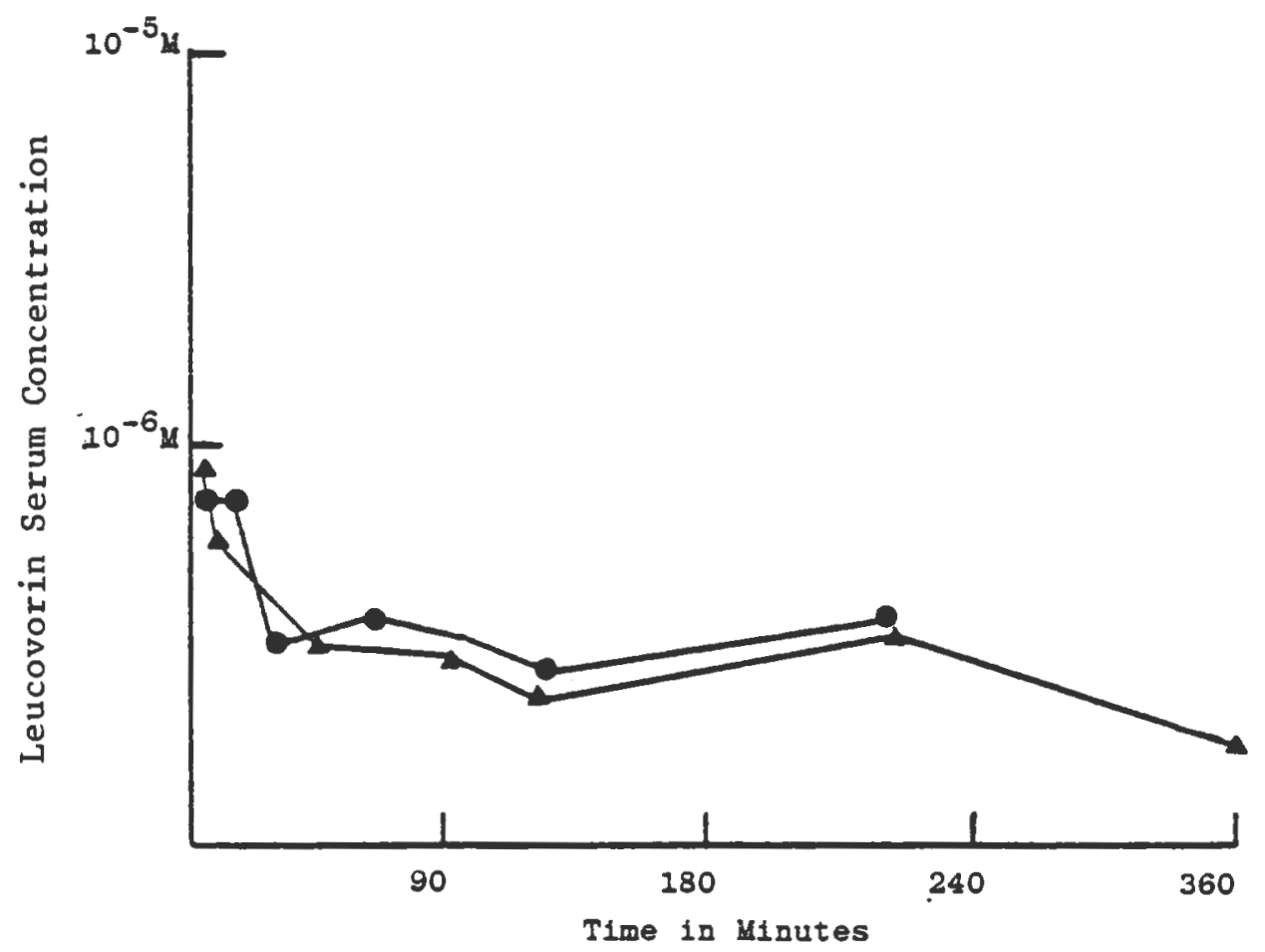

Figure 34: Leucovorin Serum Concentration as a Function of Time; Patient L.M.

Treatment Period 1

Treatment Period 2 
TABLE XV

A COMPARISON OF LEUCOVORIN PHARMACOKINETIC

PARAMETERS DERIVED FROM NORMAL SUBJECTS

AND CANCER PATIENTS

\begin{tabular}{|c|c|c|c|c|c|c|}
\hline \multicolumn{2}{|c|}{ Parameter } & \multicolumn{3}{|c|}{$\begin{array}{l}\text { Normal Volunteers* } \\
(\text { Mean + S.D. })\end{array}$} & \multicolumn{2}{|c|}{$\begin{array}{l}\text { Cancer Patients* } \\
\text { (Mean } \pm \text { S.D.) }\end{array}$} \\
\hline $\mathrm{Kel}^{\mathrm{a}}$ & Min. -1 & 1.14 & \pm & 0.43 & 1.20 & 0.69 \\
\hline $\mathrm{K} 12^{\mathrm{a}}$ & Min. -1 & 1.12 & \pm & 0.23 & 1.16 & 0.21 \\
\hline $\mathrm{K} 21^{\mathrm{a}}$ & Min. -1 & 2.25 & \pm & 0.49 & 2.90 & 0.60 \\
\hline Vd (Cen.) & Li ters & 7.41 & \pm & 3.48 & 4.06 & 0.73 \\
\hline Vd (SS) & Liters & 11.31 & \pm & 5.62 & 5.69 & 0.96 \\
\hline Vd (Beta) & Liters & 26.40 & \pm & 9.24 & 17.51 & 2.26 \\
\hline Vd (Ext.) & Liters & 29.23 & \pm & 9.78 & 19.07 & 2.68 \\
\hline Vd (Tiss.) & Liters & 3.90 & \pm & 2.16 & 1.63 & 0.24 \\
\hline Clearance & $\mathrm{Ml} / \mathrm{Min}$ & 74.9 & \pm & 19.4 & 46.4 & 20.4 \\
\hline$t^{\frac{1}{2}}(A 1 p h a)$ & Min & 8.66 & \pm & 2.98 & 5.62 & 0.59 \\
\hline$t^{\frac{1}{2}}($ Beta) & Min & 240.48 & \pm & 44.03 & 2.68 & \pm 131.43 \\
\hline
\end{tabular}


TABLE XVI

COMPARISON OF EXPECTED INITIAL LEUCOVORIN SERUM

CONCENTRATIONS TO CALCULATED LEVELS

Patient Expected Concentration

(Moles/Liter)

Calculated Concentration

(Moles/Liter)

$\begin{array}{lllll}\text { F.F. } & 1.50 \times 10^{-7} & 1.77 \times 10^{-6} \\ \text { L.M. }-1 & 3.50 \times 10^{-7} & 1.65 \times 10^{-6} \\ \text { L.M. }-2 & 4.20 \times 10^{-7} & 1.47 \times 10^{-6}\end{array}$


Page 183

TABLE XVII

COMPARISON OF PHARMACOKINETIC PARAMETERS

FOR LEUCOVORIN AND METHOTREXATE

\begin{tabular}{|c|c|c|c|}
\hline Parameter & $\begin{array}{r}\text { LEL } \\
\text { (Mean }\end{array}$ & \pm S.D.) & $\begin{array}{c}\text { MTX } \\
(\text { Mean } \pm \text { S.D. })\end{array}$ \\
\hline Half Life (Alpha) (Min.) & 8.79 & 4.44 & $44 \mathrm{~min} . \pm 6.6$ \\
\hline Half Life (Beta) (Min.) & 231.46 & \pm 31.76 & 120 min. -240 \\
\hline Half Life (Gamma) (Min.) & -- & $-\infty-\infty$ & $624 \min .-1620$ \\
\hline Vd (Central) (Liters) & 5.49 & 3.53 & \pm 1.09 \\
\hline Vd (SS) (Liters) & 8.44 & 5.73 & \pm 15.6 \\
\hline Binding to HSA & & $70 \%$ & $60-87 \%, 45 \%$ \\
\hline
\end{tabular}


page 184

of distribution reported for MTr. and the values obtained for IEO in the current study. It is evident from these data that MTX pharmacokinetic paraneters differ greatly fron those of IEO and therefore cannot be used to correctly predict its disposition. Two patients fron whon serum samples were obtained showed patterns of IEU disposition distinctly different from other subjects. Patient P.P. receired IEO, $1.1 \mathrm{~g} \mathbf{m}^{-2}$. Intravenously 36 hours after the end of mTX infusion. A plot of the serum IEd concentration as a function of tine is shown in Figure 35. Rather than the biphasic disposition evident in the other cancer patients and all normal subjects, an essentially constant level of IEU was detected in the patients serum. During the period of sample collection, hour 36 to 42 post infusion, a change in the elinination of MTX in this patient was observed. The half-life (beta) had increased fron the normal value of 2 to 4 hours to approxinately 22 hours indicating a significant decrease in the rate of ITX clearance. No indication of changes in P.F.'s renal or hepatic function vere observed during the change in ITX clearance and the event has been unexplained. It is possible hoverer, that the cause of decreased $1 \mathrm{TX}$ clearance observed in this patient ay also be responsible for the change in the disposition of LEO which was observed in P.F. 
page 185

Patient F. I. received $12 \mathrm{gg}$ - of LEO intranuscularly 48 hours following the end of urx infusion. This was the fourth dose adninistered to the patient. Figure 36 is the plot of the IEU serum concentration as a function of time for F. I. The serum concentration resained essentially constant over the 2 hour sampling period. This may be explained by the release and or absorption characteristics of the drug from the intranuscular injection site. vore data would be required to be able to characterize the intramuscular route of administration as providing a slow release rate of IEO and acting as a slow-infusion.

3. Comparison of Leucovorin Pharmacokinetics derived from Microbiologic Versus Electrochenical Assay Hethods

Spray and ritts (1953) described the utilization of intravenously administered IEO in normal subjects. LEU vas assayed using the microbiologic disc method of sauberlich and Baumann (1948). Recently Rothenberg et al. (1979) published a radiochemical assay for IEO in serum and urine. The disposition of LEU characterized by the two nethods are very much different. The early work describes a rapid derline in serum concentration whereas Rothenberg et al= (1979) found a second slow elinination phase after the initial distributive phase. A comparison of pharmacokinetic paraneters derived from the two methods was 
Page 186

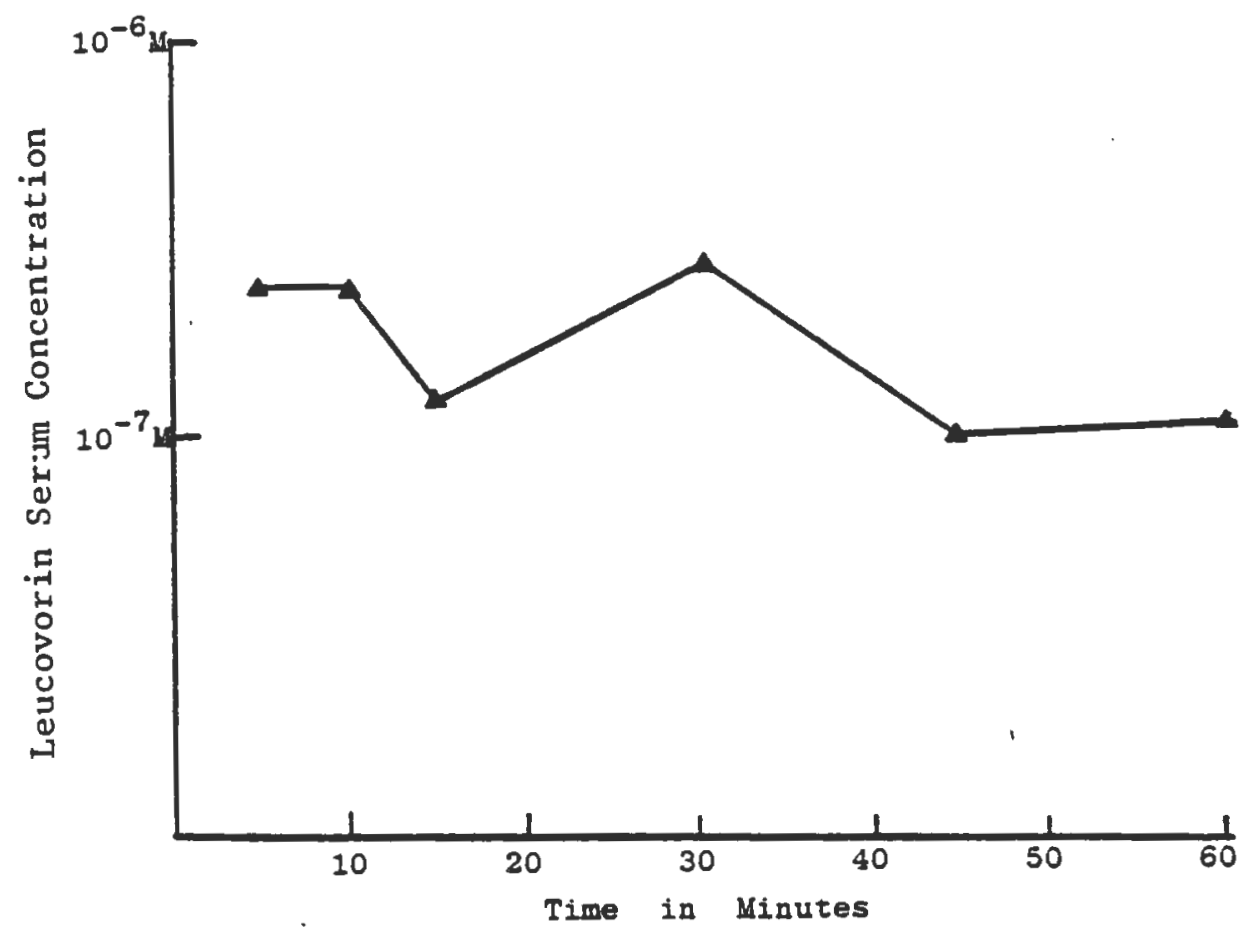

Figure 35: Leucovorin Serum Concentration as a Function of Time; Patient P.F. 
Page 187

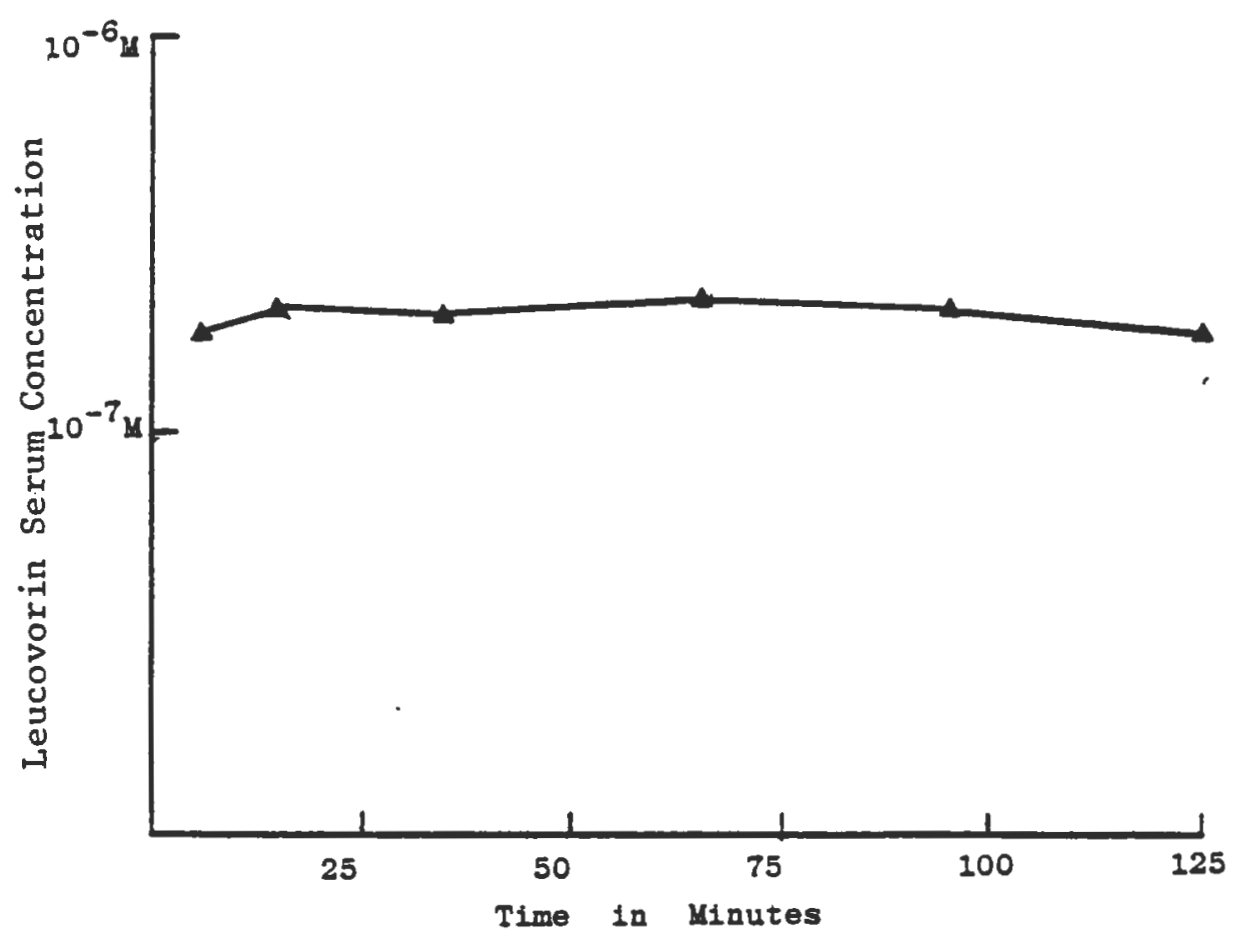

Figure 36: Leucovorin Serum Concentration as a Function of Time; Patient F.Y. 
page 188

performed using the plasna concentration-time data published by spray and iitts (1953).

The data obtained from three normal male subjects given $1 \mathrm{mg}$. of IEO intrarenously (Spray and Ritts. 1953). were first analyzed using atToAn to yield initial estimates of the aicroconstants. The data appears to be best described by a two compartnent open nodel as was the case in the current work. These estimates vere then used to obtain final values for the pharmacokinetic paraneters using NOHIIN as previously described.

Table XVII shows the parameters derived from each assay method in 3 nornal male subjects. statistical differences ( $p$ < 0.05 ) vere found in sereral of the parameters; kel, k12, alpha, beta, Vd (extrap.). clearance and half-life (beta). Figure 37 is a computer generated graph of serun concentration as a function of time using the paraneters derived fron the IEJ serun analyses. The y-axis intercepts are different because the studies used different doses in the subjects. Evident in Figure 37 is the apparently faster rate of elinination described by the nicrobiologic methoa. The half-life (beta) is $32.03 \pm 3.82$ min versus $231.46 \pm 31.76$ min when neasured by the electrochemical method. Rothenberg et als (1979) attributes the difference in elinination rate evident between the nicrobiologic and radiochemical methods to the inability of the latter to distinguish between the active and inactive diastereoisoners of IEU. They have further 
page 189

speculated that the sustained elevated seran IEO

concentration is caused by a preferrential excretion of the active isomer. conclusions regarding the excretion of only the active form of IEO are not possible from the current work. Howerer. these data are in agreenent with Rothenberg et al. (1979) in describing a prolonged elinination phase. 
TABLE XVIII

A COMPARISON OF

PHARMACOKINETIC PARAMETERS CALCULATED

FROM MICROBIOLOGIC ASSAY

VS. ECD METHOD

Parameter

Microbiologic

Electrochemical

(Mean \pm S.D.)

(Mean \pm S.D. $)$

\begin{tabular}{|c|c|c|c|c|c|c|c|}
\hline $\operatorname{Ke} 1^{* a}$ & Min. -1 & 6.15 & \pm & 4.60 & 1.14 & \pm & 0.43 \\
\hline $\mathrm{K} 12^{* \mathrm{a}}$ & Min. -1 & 1.79 & \pm & 0.37 & 1.12 & \pm & 0.23 \\
\hline $\mathrm{K} 21^{* a}$ & Min. -1 & 3.20 & \pm & 0.28 & 2.25 & \pm & 0.49 \\
\hline Vcl & *Min. -1 & 56.10 & \pm & 12.70 & 7.49 & \pm & 1.94 \\
\hline Vd (Cen.) & Liters & 9.14 & \pm & 2.07 & 7.41 & \pm & 3.48 \\
\hline Vd (SS) & Liters & 14.20 & \pm & 2.12 & 11.31 & \pm & 5.62 \\
\hline Vd (Beta) & Liters & 25.48 & \pm & 3.56 & 26.40 & \pm & 9.24 \\
\hline Vd (Extrap) & Liters & 62.18 & \pm & 10.18 & 29.23 & \pm & 9.78 \\
\hline Vd (Tiss) & Liters & & & & & & \\
\hline $\begin{array}{l}\text { Half-Life } \\
\text { (Alpha) }\end{array}$ & Min. & 7.81 & \pm & 0.68 & 8.66 & \pm & 2.98 \\
\hline $\begin{array}{l}\text { *Half-Life } \\
(\text { Beta) }\end{array}$ & Min. & 32.08 & \pm & 3.82 & 240.48 & \pm & 44.03 \\
\hline
\end{tabular}

*Statistically Different $(\mathrm{p}<0.05)$

$a=x 10^{2}$ 
Page 191

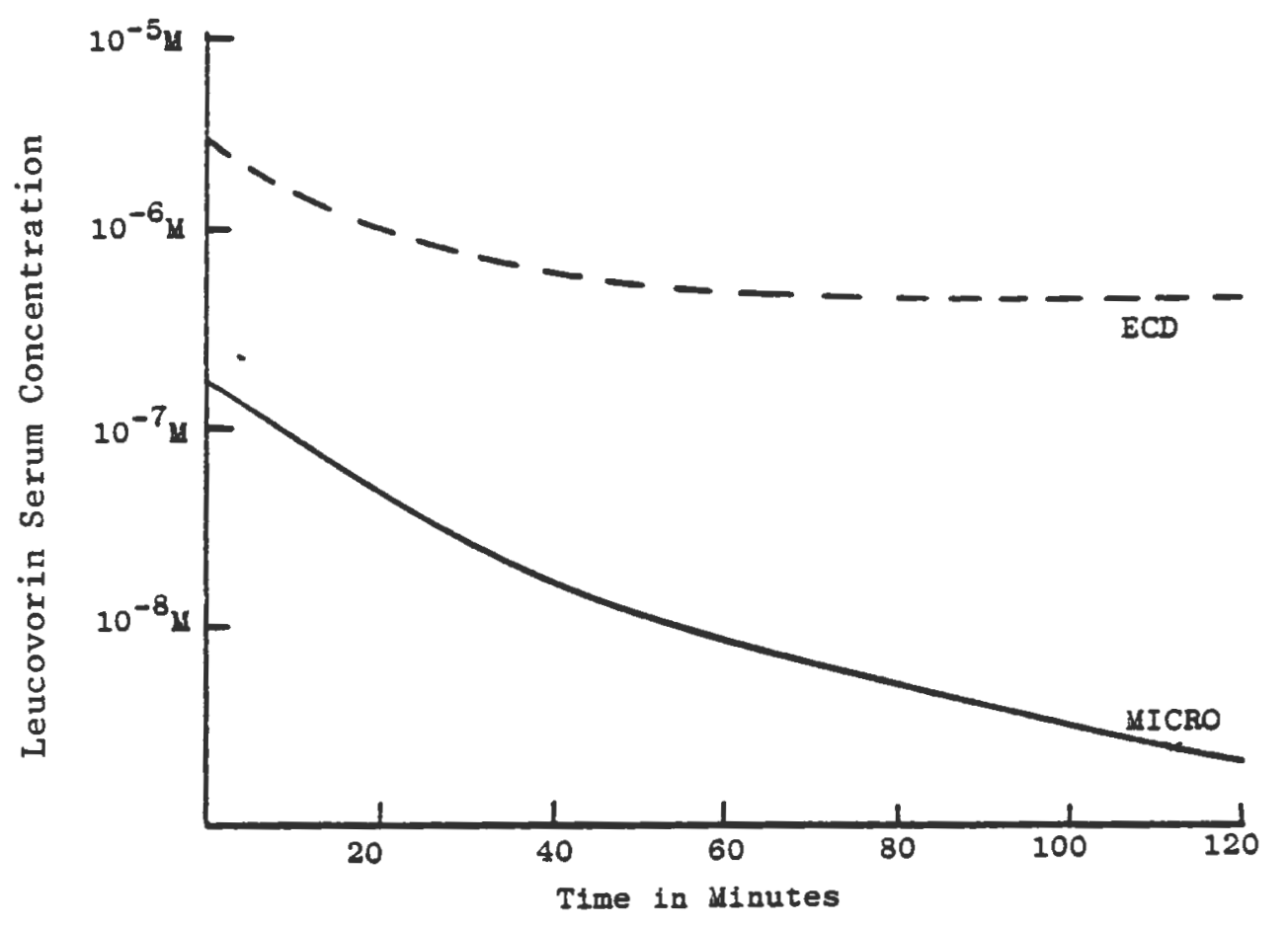

-

Figure 37: Leucovorin Serum Concentration as a Function of Time. A Comparison Using Pharmacokinetic Parameters Derived from Two Assay Methods. ECD = Electrochemical; Micro = Microbiologic. 
page 192

\section{COHCLUSIONS}

1. High pressure liquid chromatography was coupled with electrochemical detection and a sensitive, selective, and reproducible assay for LEU and UETHF was developed.

2. The electroanalytical detection of reduced folates relies on the oxidation of the electroactive species at a surface electrode. The rate of oxidation, and therefore the generated current, can be affected by the electrode naterial. the buffer strength of the supporting electrolyte, and the strength of the applied potential. Oil-based, wax-based, and solid electrodes were investigated; solid glassy carbon electrodes were found to provide the optimum balance of durability and sensitivity. anonium phosphate, dibasic, was determined to be a suitable supporting electrolyte over a wide $\mathrm{pH}$ range, with which low background current and adequate sensitivity was achieved. Raising the applied potential increased, up to a limit, the background current and the current produced ria oxidation of electroactive species. An applied potential of 0.8 rolts produced adequate sensitivity for the reduced folates and mininized the oxidation of interfering conpounds from serum samples. METHF vas more easily oxidized than LEO. With a limiting current of 0.3 rolts 
page 193

compared to 0.8 rolts for LEU. The lower limit of detection for these folates was approximately $12 \mathrm{ng}$ -

3. Eeverse-phase paired-ion chromatography was used to effect the separation of LEO and METHF in aqueous systems and the separation of LEV from the extracted components of human serun. Bowever, this method was not of adequate efficiency to separate METHF from all conponents of serum. The restraints upon the chromatographic conditions imposed by electrochemical detection severely limited the efficiency of octadecyl silane stationary phases (C-18 columns). In order to effect separation of LEU fron other plasma constituents it was necessary to use the recently developed RCSS methodology- This technique was evaluated in considerable detail and found to offer several significant advantages orer conventional reverse-phase columins.

4. A wethod for the extraction and essentially complete recovery of IEU from human serum has been developed. The applicability of this technique to other forms of reduced folates would depend upon their aqueous and orgaric solubilites, ability to form a paired-ion complex, and stability during evaporation and storage.

5. The binding of LEO and METHF to huan serun albumin was determined. Binding was not saturated over the drug 
page 194

concentration range investigated. The presence of both LEO and HETHF in the albumin solution significantly reduced the degree of binding for both arugs. Since other forms of folates are found to varying degrees in human blood, it is possible that in riro binding of the reduced folates is substantially less than was determined from in vitro experinents.

The addition of arx to albuein solutions containing IED or Hetrip had no significant effect on the degree of binding of the reduced folates. Thus, it is concluded that MI and the two reduced folates studied probably do not share a common binding site. The apparent absence of a protein binding interaction is important clinically. From these data it may be concluded that the administration of LEO following high-dose MTX therapy would not likely alter the equilibrium between free and bound plasma MT anounts or cause a redistribution of intracellular or extracellular HTX. Ho conclusions, hoverer, can be draun regarding the possible interaction between LEO, AETHF, and ATX for proposed active transport mechanisms into cells.

6. The pharmacokinetics of IEO vere characterized in 6 normal subjects and in 5 patients undergoing high-dose MTX therapy- No significant differences in pharmacokinetic parameters betveen the two groups were observed. IEU dosing protocols ai for concentrations that are ten times higher than are necessary for effective rescue. The current work 
page 195

suggests that such protocols for LEO dosing, based on MIX pharmacokinetics, result in plasma or serum LEU

concentration in excess of even these guidines. Although high serum IEO concentration pose no threat of toxicity. and can effectively reduce atx related toxicity. the effectiveness of the high-dose MTX therapy may be reduced.

It may be concluded that IEO concantrations achieved in cancer patients are higher than necessary for effective rescue and, most importantly. mu decrease the effectiveness of MIX. Based on the pharmacokinetic parameters calculated from cancer patients, a reduction of $50 x$ in LEO doses ma be possible and would be expected to: 1. improve the efficacy of MTX therapy and; 2. maintain the effectiveness of LEO rescue regimens.

\section{Future Dork}

Several possibilites for further investigation have resulted from this work:

1. The electrochenical requirement for relatively high ionic stresgth buffers may substantially reduce the efficiency of some high pressure liquid chromatographic systems. In the current work calculated colunn efficiencies were reduced by approximately $80 x$ from the claimed column efficiencies.

The use of post-colum addition of supporting 
page 196

electrolyte may represent a solution to this problem. In this manner, chromatographic conditions may be optimized uith fever concessions to electrochemistry than are currently possible. Such an approach might be expected to produce greater resolution asd efficiencies in HPLC and most likely lower the limits of sensitivity.

2. The renal clearance of IEU has received littie attention. Furthermore, published reports have not adeguately performed arine sampling with regard to proper pharmacokinetic analysis. Therefore, reliable estimates of the total amount of IEO excreted in urine are not available. The current assay method could be applied to an adequately designed pharnacokinetic study. resulting in the characterization of the renal and netabolic clearances of IEO.

3. The extraction procedure described in the current vork was not suitable for the analysis of IETHF. METHF can be quantitatively deternined at an oxidation potential of 0.3 volts. rather than the 0.8 Volts necessary for the oxidation of LED. BY decreasing the applied potential, the oxidation of serun constituents is expected to be reduced considerably. Onder this condition it may be possible to derelop an extraction process for METHF that would allow for the determination of its pharmacokinetics in hunans. 
page 197

4. There is considerable interest in qualitative and quantitative analysis of reduced folates (monoglutamates) and various polyglutanates within cell. The concentrations of these conpounds is below the limit of sensitivity achieved for the reduced folates. Modifications in the electrochenical cell, including increased electrolyte cell surface, repositioning of the auxiliary electrode, and decreasing the diffusion distance within the cell way be expected to provide greater levels of sensitivity- Coupled with the improved chromatographic technigues suggested above, this approach may lead to the derelopment of a system suitable for the detection of intracellular folates and polyglutamates. 
REPERENCES

1. Acute Leukenia GIoup B.. J.A. H. A. 194, 187 (1965).

2. Alerander, M. and Greenberg, j-: J. of Biol. Chem. 214, 821 (1955).

3. Alter, H.J., Zvaifler, H.J., and Rath C. E.: Blood 38. 405 (1971).

4. Anonyous, Amicon Product Literature (1977).

5. Anonymous, A.S. B. P. Leucororin Honograph (1980).

6. Anonymous, + SIGMA Product Iiterature (1980).

7. Atuma, S. and lindquist, J: Analyst $\underline{9}_{2}$ 886 (1973).

8.. Baker. B.. Frank. O.. and Feingold, J.; An. J. Clin. Natr. 17e 88 (1965) -

9. Bardos, T. et alee J. Am.

Chem. Soc. II. 3852 (1949).

10. BendeI, J.F., Grove, R.R, Partner, C.I.; An. J. Hosp. Pharm. . $34_{2} 961$ (1977).

11. Benhold. Ho. in Transport Function of Plasma Protein; P. Desgres, P. M. Detraverse, Ed., Elsevier, Amsterdam. Hetherlands, 1 (1966).

12. Bernbaun H.C.., and Brown, I. H.; Inmunol. 8. 251 (1965).

13. Birminghan, B.K., Stoller, R.G., Kaplan, H.. Cunnings. F.., and Greene. D.S.; AACB Proceedings $2 \underline{2} 209$ (1979).

14. Bishoff, R.B., Dedrick, R.I, Zaharko, D. S.. : J. Phara. Sci.. 59 (2) 1761 
15. Bischoff, K. B., Dedrick, R L., Zaharko, D.S., and Longstreth, J.A.; J. Pharn. Sci.. 6므. (8) 1823 (1971).

16. Blacow, M. H.. Bd., Martindale Extra Pharmacopeia (1980)

17. Blair, J. .., and Saunders, V. J.: Analyt. Biochen.. 344376 (1970).

18. Blakely. R.L.: Biochew. J. 58, 448 (1954).

19. Blakely. R.L.; Biochen. J. 65. 331 (1957.

20. Blakely. R.I.. The Biochenistry of

Folic Acid and Related pteridines, in Frontiers of Biologye Bd. by A. Neuberger and E.L. Tatu. N. Bolland Publishing Company. Amsterdaw, (1969).

21. Blyer. M.A.; Ca. Treat. Rer., 487 (1977).

22. Borga, O., zarnoff, D.I, Fonshell, G.P.. Sjogrist. F.: Biochem. Pharmacol., 18 2135 (1969).

23. Borsa, J.. Mhitmore, G.F.: Mol. Pharmacol.. $5_{2}$ 318 (1969).

24. Brockman, J. et ales J. An. Chen. Soc.: 72, 4225 (1959).

25. Brown, J.P., Davidson, G. E., Scott, J. H..; J. of Chromat.. 19, 195 (1973).

26. Buchta, R-C., Papa, I. J.; J. Chron, Sci.. $14(5), 213(1976)$.

27. Burchenal. J.H.: Proc. Soc. Exper. Biol. ned. I1, 559 (1949).

28. Burchenal. J.H.; Proc. Soc. Exper. Biol. Med. 74. 735 (1950).

29. Burchenal, J.H. . Maring, go, Hellson, G.. Reilly. H.C.A: Proc. Soc. Exp. Biol. Med., 78. 603 (1951).

30. Bush, H-T., and AIvin, J.D., N-I, Acad. Sci, 226 36 (1973). 
31. Calabresi, P.., and Parks, R. E.: Chemotherapy of Neoplastic Diseases in. A Pharnacologic Basis of Therapeutics, Ed. by. A. Goodman, and L. Gillman, Eds. (1970).

32. Calbiochen Inc., personal comunication. (1980).

33. Capizze, R-L., Deconti, R-C., Marsh, M-C., and Bertino, J.R.; Ca. Resch., 30. 1782 (1970).

34. Chabner, B-A-, and Young, R-C.; J. Clin. Invest 52. 1804 (1973).

35. Chabner, B.A... et ale; H. E.J.H, 292 1107 (1975).

36. Chanarin, I. Anderson, B. B, and vollin, Do L.; Brit. J. Haemat.. 4 156 (1958) -

37. Chanarin, I., Perry, A.; Biochenical J. 105 $633(1967)$.

38. Chanarin, I., Perry, A-: Brit. J. Haemt., $1 \underline{B}_{2} 691$ (1970).

39. Chanarin, I., Hclean, A-; Clin. Sci.. 32. 57 (1967).

40. Chapman, S-K., Greene, B-C, Streiff, R-R-: J. of Chromat. 14 $\underline{5}_{\text {, }} 302$ (1978).

41. Chigne11, C. F-; in Drug Pate and vetabolism, E. Garrett, J. L. Birtz, Eds, Vol. 1.. Darcell Decker, New York. (1979).

42. Chignell, C.P.: Concepts of Biochemical Pharmacology, Spring, 8. Y.. 137 (1971).

43. Condit, P.T., and Grob, D.; Cancer, Philad. 11. $525(1958)$.

44. Conti, V.J., Suter, H., and Bidler, R; Helretica. Chimica. Acta $\underline{5} \underline{z}_{\text {\& }} 161$ (1974).

45. Cosulich, D.: J. A. Chem, Soc., 글. 3252 (1952).

46. Creaven, P.J., Nanse, H-H., Alford, D. A, Allen, - L. A.; Br. J. Ca., 28, 559 (1973). 
47. Curry, S.H.: J. Pharm- Pharmac., 22. 753 (1970).

48. Dayton, P.G. Israili, 2. H., and Perel, J.H.; H. Y. Acad. Sci. 226. 172 (1973).

49. Dedrick, R-I., Zaharko, D.S., and Lutz, R.J.: J. Pharm. Sci.. 62. (6) 287 (1973).

50. Denko, C.S.; J. Appl. Physiol. $\underline{3}_{2}$ 559 (1951).

51. Dixon, R.C.; Fed. Proc.. 24454 (1965).

52. Djerassi, I.: Clin. Pediatr. S, 502 (1966).

53. Djerassi, I., et al $\underline{1}_{\text {i }}$ Cancer $\underline{2}_{2}$ 233 (1967).

54. Djerassi, I. ; Cancer Res.. 27, 2561 (1967).

55. Djerassi. I. et allei Proc. An. Assoc. Ca. Res.. 9. 18 (1968).

56. Djerassi, $I_{\mu}$ et $\underline{\text { l }}=i$ Cancer, 20 , 22 $(1970)$.

57. Djerassi, I. . Roninger, C. J., and Kima, J.S.: Cancer 30 , 22 (1972).

58. Djerassi. Io : Ca. Chemo. Rept. Pt. 3. $6(1), 3(1975)$.

59. Donaldson, K. O., and Keresztesy, J. C.; J. Biol. Chemo 23보. 3235 (1959).

60. Donaldson, K, $0_{-}$, and KeresztesY, J-C.: Fed. Proc. 20. 453 (1961).

61. Donaldson, K, O.., and Keresztesy, J.. C.; J. Biol. Chem. ; 237 e 1298 (1962).

62. Duggan, D.E., Bowman, R. L, and Brodie, B. B.; Arch. Biochen. Biophys., $\underline{6} \underline{8}$

1 (1957).

63. Elsborg, I.; Acta. Haematol., 48 207 (1972). 
64. Farber. S., et allei M.E.J.H.. $238787(1948)$.

65. Pellick, G.J., and Raushc, C. I.: An_ Lab.. 11. 87 (1979).

66. Flanent-Durant, Ketlebant-Balasse, Haus P. et alle:

67. Fleet, B., and Little, C.J.; J. Chrom. sci.. 12(12) 747 (1974) .

68. Fletcher, J.E., and Ashbrook, J.D.; Ann. N.I. Acad. Sci.. 2266. 69 (1973).

69. Fosdick, M.L.: Hed. Clin, D. Am-; 52. 747 (1968).

70. Freewan. H. . J. Pharmacol. Exper. Ther.. 122 . 154 (1958).

71. Gillette, J.B.; Ann. A.I. Acad. Sci., 51, 660 (1973).

72. Gilpin, R. R., and Sisco, H.R.; J. Chromato 194, 285 (1980).

73. GIOOI, R., and Johnson, E.L.; J- Chrom. Sci.. 15, 413 (1977).

74. Goldin. A-: J. Hatl- Ca. Inst. 11. 203 (1956).

75. Goldin, A.: Ca, Treat, Rep. . 62/2Le 307 (1978).

76. Goldin, A.: Inunol. $\underline{8}_{2} 251$ (1965).

77. Goldin, A., Et alli Ca. Rsch., 13 843 (1953)

78. Goldin, 1.: et als Ca Rsch. 14. $43(1954)$.

79. Goldin. A. ett allei Ca Rsch $1 \underline{5}_{2}$ 742 (1955).

80. Goldin, A. et ale: Nature 212 1548 (1966).

81. Goldin, A., Mantel, M., Greenhous, S. D. ets allei Ca. Rsch. . 13 $=843$ (1953). 
82. Goldin. A.. Vendetti. J.H.. Klein, k., et al=i Nature 212 , 1548 (1966).

83. Goldman, I.D.: Ca. Chemother. Rep., $6_{2}$ 51 (1975).

84. Goldman. I.D.: Eol. Pharmacol.. 10, $257(1974) \ldots$

85. Greenspan, E. . Goldin, A., and Schoenbach, E. B.: Cancer. 3856 (1950).

86. Greenberg. Ho S., And Hayer, H.J.; J. of Chromatog.. 169, 321 (1979).

87. Grossovicz, N, et alei Blood, 20, (5) 609 (1962).

88. Gupta, V.S., and Huennekens, F. H.: Arch. 'tbiochem. Biophys.. 120, 712 (1967).

89. Ball, I. C., Roberts, D., and Kessel, D. H.: Europ. J. Ca., 2, 135 (1966) -

90. Harrison's Principles of Internal Medicine Ed. by H. H. Dintrobe, 7th Ed.. Mcgrav Hill. New Iork (1970).

91. Hashimoto, H.. and Maruyama, I.; J. of Chroma. 152 387 (1978).

92. Henderson, E.S., Adanson, R. H., and Oliverio, V.T.; Ca. Rsch, 25, 1018 (1978).

93. Herbert, V.. Larrabbe, $A-R$, and Buchanan, J.H.: J. Clin. Inv. 41 , 1134 (1962).

94. Horvath, C.. and Melander, M.: J. Chron. sci.. 15, 393 (1977).

95. Horvath, C., and Melander, H.: Am. Lab. . 10, 27 (1978).

96.. Boward, G.A.., and Martin, A.J., P.. Biochen. J. 느, 532 (1950).

97. Hughes, W.1.: The Proteins of Blood Plasma in "The Proteins". Neurath, H.. and Bailey. K., Eds.. Vol IIB, Chap. 21, Acadenic press. H. I. (1954).

98. Huffman, D.H., Man, S. H., Azarnoff, D. I.. and Hoostraten, B.: Clin. Pharm. Therp. 


$$
\text { 14. } 572 \text { (1973). }
$$

99. Hutchison, D.J., and Burchenal, J.H.;

100. Jaffe, N., Chu, H.B.B., Prei, e. et ale; N.E.J.H. 291119Le 994 $(1974)$.

101. Johanson. I. H. Mahlond, K.G., and Schill, G.: J. Chromat., 14툐 281 (1978).

102. Jacobs. S.A.. Stoller, R.G.. Chabner. B-A.- and Johns, D.G_; J. Clin. Invest. $5 I_{-}$ 534 (1976).

103. Johns, D.G., Sperti, S., and Burgen, A.S. V.: J. Clin. Invest.. 40 $1684(1961)$.

104. Johns, D.G.. Hollingsworth, J.. et al J. Clin. Invest. . 43. 621 (1964).

105. Kamen, B. A., and Caston, J.D., J. Lab. Clin. Med.. 83(1) 164 (1964).

106. Kastru, E.K.. and Boyd, I. R.; Pacts and Conparisons, (1980)

107. Reller, R, Oke, A.. Mefford, I., and Adams, R.N-: Iife Sci-. 19. 995 (1976).

108. Kenula. M.. Rocz. Chen. 26,281 (1952). in Kissinger. Clin. Cher. 992 (1974).

109. Reresztesy. J.C.. Silverman, H.; J. Am. Chen. Soc.. 13. 5510 (1951).

110. ReresztesI. J.C.. and Donaldson, R. . : Biochen. Biophys. Res. Com., Se (4), 286 (1961).

111. Reresztesy, J. C., and Donaldson, K. O.; Biochen. Biophys. Res. COm.. 5e(4), 289 (1961).

112. King. T.P.; N.I. Acad. Sci 226. (1973)

113. Kisliuk, R.L., and Sakami, M.: J. Biol. Chem. 214, 821 (1955).

114. Kissinger, P.T. et al. Anal. Let. 6 (5Lle 465 (1973).

115. Kissinger, P.T., Clin., Chem.. 20. 
992 (1974).

116. Kissinger. P- T. : Anal, Chem., 46(5). 15 (1974).

117. Kissinger. P. T.: Anal. Chen., 49. 447 a (1977).

118. Kissinger. P. T. et alei J. Chrom. Sci. . 1Ie 137 (1979).

119. Kissinger, P.T-; Bioanalytical Systens product Iiterature, to be published.

120. Klotz, I. A.; arch. Biochen,. If $109(1946)$.

121. Klotz, I,H_; H.I. Acad. Sci_, 226 18 (1973).

122. Knox, J.H.; J. Chrom. Sci., $1 \underline{5}_{2}$ 352 (1977).

123. Kunin, C.H.: H. Y. Acad. Sci., 145 282 (1967).

124. Langone. J.J., and Levine, I. : Anal. Biocheme. 95 e 472 (1979).

125. Lange, Current Diagnosis and Treatment (1973).

126. Lankelma, J. and Poppe, H.: J. Chromat.. 125. 375 (1976).

127. Lankelma a.. J. and Van der Kleijn, E;

a. of Chrovat, 182, 35 (1980) -

128. Larrabbe, A. B., and Rosenthal, S.;

Fed. Proc.. 20, 9 (1961) -

129. Larrabee, A. R.. Rosenthal, S. and Cathou, Bo; J. An. Chem. Soc., 83 e $409 a(1961)$.

130. Lefkowitcz, E., Papac, R.J., and Bertino, J.R.; Ca. Chem. Rept., 51, 305 (1967) .

131. Lehninger, d.I., Biochemistry; North Publishing House N. 1.. (1970).

132. Levitt, H.. Mosher, B. B., and Deconti, R. C.: Cancer Res.. $33_{2} 1729$ (1973). 
133. Lery, G.. ana Yacobi, A. B.: J. Pharm. Sci.. 63, 805 (1974).

134. Liegler. D.G.. Henderson, E, S, and

Hahn. H. A-; clin. Pharm- Therap.. 10, $819(1970)$.

135. Little, J.N. , Cotter, R-I., Prendergast, J.A. MacDonald, P.D.: J. Chronat, 126 e 439 (1976).

136. Innd, I., Lunde, P-K., Krane, A. Borga, O.. and Sjogrist, F.; Anal. N. I. Acad. sci.. 179, 723 (1971).

137. MacDonald, A... and Duke, P.D.; J. Chroma. 83 , 331 (1973).

138. Darkannen, T., and Pelota, j-; Acta. Haenatol, 43. 272 (1970).

139 Markkannen, T; Life Sci, I, 887 (1968).

140. Markkannen, T., Virtanen, S.. Himanen, ;P.. and Pajula. R.I.: Acta Haem. $\underline{4}_{\underline{6}}$ $213(1972)$.

141. MaY, H.. Bardos, T.J.. and Barger, F. L. ; J. An. Chen. Soc., 73. 3067 (1951).

142. HCLean. A. and Chanarin, I.: Blood. 27. 383 (1966).

143. Mehta, B.M., Conti, M. H., and Gisolfi, H-;

Ca. Treat. Rpt. 62 (3) 345 (1968).

144. Uehta, B.B., and Hutchinson, D.J.; Ca. Treat. Rpt. 61(9) e 1657 (1977).

145. Methotrexate Product Literautre, Lederle Laboratories. (1980).

146. Hetz, J.. Zalusky, R, and Herbert, V.: Amer. J. Clin. Nutr. 21, 289 (1968).

147. Hetzler, C.. Elfring, G.L, and MCEwen, A. J.; Bionetrics 30 (3) (1974).

148. Heyer, H.C., and Guttman, D.E., J. Phara. Sci.. 5 工 895 (1968). 
149. Hontgomery. et als in Adrances in Chromatography. J. Calvin Dgidding, Ed. (1975).

150. Horselli. P. L.: Biochen. Pharaacol. : 19e $1846(1970)$.

151. Dosher. F.: Personal Communication (1978).

152. Munson, J.M.. Meiersta11, R.. and KostenbaudeI. H.B.: J. Chromat. $145_{\ell} 328$ (1978).

153. Nea1, G. E., and Dillians, D.C.: Biochen. Pharmacol, 14e 903 (1965).

154. Nichol, C. A. and Relch, AnDo; Proc. Soc. Exper. Biol. and Hed.. 74, 403 (1950).

155. Nixon, P-P.; Clin. Exp. Phare. Phys. suppl 5,35 (1979).

156. Nixon, R.F., and Bertino, J.R., Blood, 36. 857 (1970).

157. Nixon, P.F., and Bertino, J.R-, M. E.J. .... 286ㅛ 175 (1972).

158. Papac, R.. Lefkowitcz, E.. and Bertino, J. R-: Ca- Chemo. Rpt.: 51(2) 467 (1967).

159. Patek, A. Jo, Schiff. I.N.: in Diseases of the Liver. 3rd. Ed.. Iippincott 689 (1969).

160. Penta, J.; Ca. Chemo. Rpt.. 6(1). 7 (1975).

161., Perkins, B.L., Saith, E.J., and Saslaw. S.; Amer. H. Hed. Sci.. 25그. 116 (1969).

162. Perry. J. and Chanarin. I-: British J. Haenatol.. 18, 329 (1970) .

163. Plenderheith. I.H.. and Bertino, J. R.; N.E.J.H.. 2요, 112 (1975).

164. Pohland, A.. Plyna, E. H.. Jones, R. G, and Shive, R.; J. An. Chen, Soc., I $\underline{3}_{2}$ $3247(1951)$..

165. Ponte, L, O.. Cheung, A. P. K., and Lim, p-: in nalytical Profiles of Drug substances. Academic Press. (1980). 
166. Pratt, R.F., and Cooper, B. A-; J.

clin. Invest.. 50, 445 (1971).

167. Baso, V.: Cancer. Treat. Rept.. 61(4)L

585 (1977).

168. Reed, I. S., and ArcheI, H. C.; J. Chrom.. 121 \& 100 (1976) .

169. Reich, S. D., Bachur, H. B., Boebel, R. H., and Berman, M-; J. Biopharn. and Pharmaco.. 5 (5) $(1977)$.

170. Reif, V.D., Reaner, J.T., and Grady. Lo T.; J. Pharn. Sci., 66 $(8)$ le (1977).

171. Riggen, R.t. Schnidt, A. L., and Kissinger, P.T. ; J. Pharm. Sci.. 64 (4) $680(1975)$.

172. Ritchell, M. A-: Bandbook of Basic Pharmacokinetics. (1975) Drug Intelligence

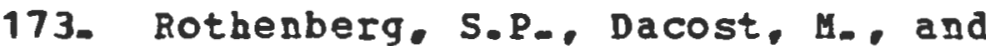
Rosenberg. A: Anal. Biochem., 93.484 (1979).

174. Roth, B.: J. Am. Chen, Soc.. I4, 3247 (1952).

175. Sacks, M.S.; Anal. Int. Hed.., 32 $80(1950)=$

176. Sadee, H.. and Beele. G.; Drug Level Monitoring Analytical Techniques, Metabolisa, and Pharmacokinetics, Riley and sons, M. I. (1980).

177. Sauberlich, H-E., and Baumang, C. A.;

J. Biol. Chew. 176. 165 (1948) -

178. Scatchard, G.; Anal. H.I. ACad. Sci.. 51. $660(1949)$.

179. Schill, G., Borg, K. O., Lodein, R., Persson. B.: in Progress in Drug Hetabolism Vol. 2. Lo R. Chasseaud and Jo H. $_{\infty}$ Bridges, Eds. Biley, London. N. I... 219 (1977).

180. Schoenbach, J.; J. A, H. A.. $144(18 \mathrm{~L}$. 1558 (1950).

181. Schrinker, H.; Amer. Lab.. 111 (1978).

182. Schwartz. P.; Doctoral Thesis, Oniversity 
of Rhode Island. (1979).

183. Scott, R-Im, Rec. Trav, Chim.. I $\underline{3}_{2}$ 787 (1965).

184. Sednan, A. J., Magner, J.G.; AOTOAN

Manual Publication Distribution, 615 East Onir. Ave.. Ann Arbor. Hichigan (1974).

185, Sellers, E.t., Koch-nesser, J., Clin. Pharm. Ther.. 11, 524 (1970).

186. Settle, N.. Hegeman, S., and Featberstone, R. M. : Concepts of Biochem Pharmacol.. 28(1) 175 (1971) -

187. Shapiro, M.R.. Young. D. F.. and Mehta. B. H... H.E.J.H. 293 (4Le 161 (1975) .

188. Shoup. R.: Bioanalytical systens. Product literature, to be published.

189. Shoup. R.. personal comnunication (1977).

190. Silverman. ... and Keresztesy. J.C.; J. Am. Chen. Soc., I3/ 1897 (1951).

191. Sirotnak, F. Hoccio, D., and Dordick, D.; Cancer Rsch.. $36_{2} 345$ (1976).

192. Spector, R.. Lorenzo, A. ... and Drum, D. E.: Biochen. Pharmacol, 24. 542 (1975).

193. Spray, G. B., and gitts, L-J.; Clin. Sci.. $2_{2} 273$ (1952).

194. Spray, G.H., and Mitts, I. J.: Clin. Sci.. 12. 391 (1953).

195. Steele, R.H., Lawrence, J.I., Stuart, J.F.B.. and McNeill, C. H.; Eur. J. Clin. Pharnacol., 15, 353 (1979).

196. StolleI, R.G., Jacobs, S. A.. Drake, J. C.. Lutz, R.J., and Chabner, B.J.; Ca. Chemo. Ther. Rept.. $\underline{3}_{2}(1975)$.

197. Stoller, R-G_: R.E.J.H., 297 . 630. (1977).

198. Stoller. R.G.. Cumings, F.. and

Calabresi, P.: Proc. Aner. Socm Clin. Oncol., 19, 344 (1978). 
199. Stoller, R.G., personal comunication (1978).

200_ Stout, R- R-. Coward, J-K., Horrath, C.G., Bertino, J.R-: Analy- Biochen., I1, 119. (1976).

201. Strauss, 0.8., Goldstein, A-: J- Gen.

Physiol.. 26, 559 (1943) -

202. Sullivan, H. V.; N.E. J. H.. 272. 340 (1965).

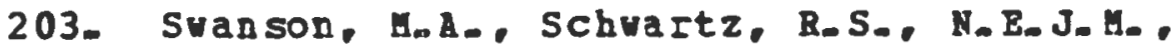
163. (1967).

204. Takata, Y., and Muto, G.; Anal. Chem-, 45 (11) 1865 (1973).

205. Tanford, C., Swanson, $M_{\infty} \mathbf{A}_{-}$, and Shore, S.; J. Am. Chem。 Soc., II, 6414 (1955).

206. Tauro, G.P., M.E.J.H., 294 (9l, 466 (1976).

207. Taylor, J-R., and Halprin, K, K-; Arch. Dermatol.. 11 $\underline{3}_{2} 585$ (1977).

208. Tyeda, K, and Rabinowitz, J.C.; Anal. Biochems. 6, 100 (1963). in Ponte, (1979)..

209. Vanscott, E. J.. Auerbach, R.., and Weinstein, G. O., Arch. Derm-, $899_{2} 550$ (1964).

210. Hagner, C., lusty, S.H., Kung, H., and Rogers, H.L_; J. Biol. Chem 241, $1923(1966)$.

211. VagneI. J.: Fundamentals of Clinical

Pharmacokinetics, Drug Intelligence, (1977). - nl

212. Han, S. B., Huffman, D.h., Azarnoff, D. L.. Stephans, R.. and Hoogstraten, B.C.: B. Can. Rsch. 34 . 3487 (1974).

213. Maxnan, J., and Herbert, V.; H. E. J.M., 28을 $1316(1969)$.

214. Thithead, V. H.. Pratt, R., Viollet, A., and Cooper. B.; BIit. J. Baen., 22, 63 (1972).

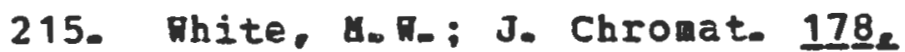
229 (1979).

216. Mightman, R. H., Paik, E. C., Borman, S., 
and Dayton, Mo 1410 (1978).

217. Millard, H. H., Herrit, I.I., and Dean, J.., Eds. Instrumental lethods of Analysis. Var Norstrand, (1976).

218. Zakrzeuski, S.F.. Sanson, A. H.;

Preparation of Folinic Acid in Methods in

Enzyology, Vol. 18, Part B, Edited by

Eccorncick, D.B., and Rright, Lo..

Acaderic Press. M. Y.. 731 (1971).

219. zettner, A., and DulY, P.E.; Clin.

Chem.. 20(10) 1313 (1974). 
TITLE OF PROPOS LL: "Pharmacokinetics of Leucovorin in Normal Subjects" PRIIICIPAL INVESTICATOR: D.S. Greene

This is to certify that the application identified above has been revietyed by the Board approved to revielv proposals for research and other activities involving human suhjects.

DATE OF REVIE!: $\quad$ February 19, 1980

COMPIITTEE ACTIOI!: Approved.

COI: EENTS.

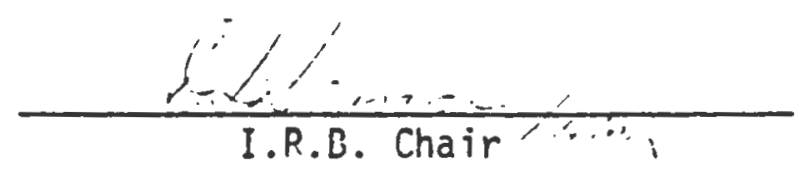

Cc: P.I. Dept. Chair Coordinator of Kesearch 
DOGEN YYIIIIAIYS

GENERAI HOSPITAI

page 212

S25 CHALRSTONE AV'ENUE

PROVIDENCE, RHODEISIAND OZ9OS

Nursing Instructions for High Dose Nethotrexzte-Ifucovortin Rescue Protocol

MIX Dose- Inftial course $1000 \mathrm{mg} / \mathrm{m}^{2}$ intravenously over 18 bours with $10 \%$ of the total dose by rapid intravenous infusion over 30 minutes. Subsequent courses ITIX dinse to be mrdifled In order to achieve a plasma level of $1 \times 10^{-4}$. M during. the MIX infusion.

\#ydration- Intravenous infusion of $3000 \mathrm{ml} / \mathrm{m}^{2} / 24 \mathrm{hrs}$. with $88 \mathrm{meg} \mathrm{HCO} / \mathrm{m}^{2} / 24 \mathrm{hrs}$. (2 amps) to be started 12 hours prior to the MIX infusion and to be continued until completion of leucovorin rescue (hour 42).

Urine PE-

MIX Infusion should not be started unless the patient's urinary pHI7.0. Urinarg $\mathrm{PB}$ should be monitored periodically-for-24hrs. following the start of IITX. The houseofficer shoul.d be notified immediately if the urinary $\mathrm{pH}$ falls below 7.0 .

Plasma MIX- Blood ( $2 \mathrm{ml}$ in 200units of heparin) should be drawn 9,18, $24,30,36,42$, and $48 \mathrm{hrs}$. following the start of MTX. Bloods should be clearly labelled with the pitient's name and hour drakn and should be stored in the refragexator on West-4.

Leucovoris - Leucovorin rescue will be given intravenously at 30,36 , and 42hrs. after the start of the MIXX infusion. Ieucovorin dose is to be calculated on the basis of the 9, J.8, and $24 \mathrm{hr}$. plasma MIXX levels. It is therefore crucial that these levels be drawn on time and that the laboratory be notiffed:. inmediately after the 24hr. MTX level. is drawn (X2087 JoAnn Aspry or Joyce Blaisdell). The Oncology fellow will notify the West-4 Unit once the leucovorin dose has been calculated. If no such notification has been recelved by hour 30 , contact Dr. Ron Stoller imediately.

Bloods- Pretreatment: CBC, platelet count, differential, BUN, sexum creatinine, creatfinine clearance, bilirubin, alkaline phosphatase, SGOT, and urinalysis.

Follow-up: Daily CBC, platelet count, BUN, serum creatinine, alkaline phosphatase, SGOT $x$ 3days.

If there are any questions please contact DE. Ron Stoller at X2055 or 2050. 
Providence, Phode Island

CONSENT FORM

page 213

THE FULL NATURE AND EXIENT OF YOUR DISEASE HAS BEEN'EXPLATNED TO YOU.

1. You are invited to particlpate in the following study: High-Dose Methotrexate with Leucovorin Rescue: A Clinical and Pharmacological Study.

You will receive the combination of high dose methotrexate and - leucovorin rescue.

2. If you decide to participate, the procedures to be followed are explained below:

These drugs will be administered by veln. It is understood that the therapy will be discontinued if severe toxicity develops or if the therapy is found to be ineffective. Also, periodic tests will be performed to neasure the effectiveness of this therapy.

3. Those procedures which are investigational have been identified as:

The investigational portion of this study involves the measurement of the effectiveness of these drugs and your tolerance to them.

4. As with any investigative procedure or medication, previously unreported or unforeseen complications may occur rarely. The following complications or risks have been reported, or are known, or may occur:

This combination of drugs has side effects wich may include any, all, or none of the following: nausea, vomiting,................... diarithea, a sore mouth and tinroat with or without sores similar to canker sores, lowering of the white blood count and/or red blood count and/or platelet count, increased risk of infection and possible kidsey damage.

5. The benefits which can be expected have been describsd as:

It is possible that your disease may be controlled by a decrease in the growth of ralignant tissue in an effective and safe manner. It is not possible to predict whetiner or not any personal benefit will result from the use of this trcatment program. 
page 214

6. The alternate procedures, if any, which would be possibly advantageous to you have been described as follows:

Other treatment programs which may include the drugs in this program or other combination of drugs similar to those in this program are avallable, but there is no clear evidence that other combinations would. provide an increased chance of controling your disease and the side effects would be sigilar to the drugs proposed in this study.

7. Feel free to ask any questions you have about the study and we will be happy ,to answer them. If you have any additional questions later, Dr. _ may be contacted through the nurse if you are hospitalized or by calling $456-2100$ if you are an out-patient.

8. Any information that is obtained in connection, with this study and that could identify you will remain confidential and will be disclosed only with your permission. If you give us your pernission by signing this document, we plan to disclose data about you, which does not identify you by name, for medical and other scientific purposes, including publications.

9. You are making a decision whether or not to participate in this study. Your decision whether or not to participate will not prejudice your future relationship with the Foger Williams General Hospital. If you decide to participate, you are free to withdraw your consent and to discontinue your participation at anytine without prejudice.

10. Please give us an indication of your having read this document by placing your initials next to each numbered item described above.

11. Your sigitature on this document indicates that you have decided to participate having read the information provided above.

PATIENT:

DAIE: TISE:

SIGNER OTHER THAN PATIENT: RELATIONSHIP :

PERSON EXPIAINING THE STUDY: DATE: IINE: PRINCIPAL INVESTIGATOR: 


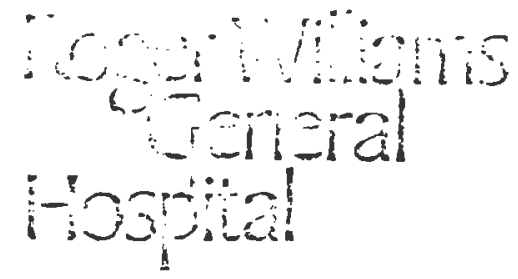

page 215

February 8,1980

Douglas S. Greene, Ph.D.

University of Rhode Island

Department of Pharmacy

Kingston, Rhode Is land 02881

Dear Dr. Greene:

As Secretary of the Ethics and Clinical Investigations Committee, I am pleased to advise you that your Progress Report of your Grant Application, Roger Williams General Hospital \#80-248-46 titled "Pharmacology of Leucovorin in Cancer Chemotherapy" ivas reviewed and approved by the Ethics and Clinical Investigations Committee at their meeting on February $7,1980$.

Under Federal and Committee Regulations, this Grant will automatically be submitted for review in February of 1981. Prior to the next review, it will be necessary for you to submit a summary regarding the activities- of this Grant.

Cordially,

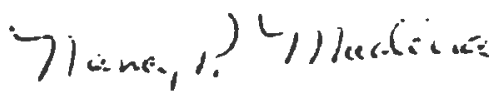

Nancy P. Madeira, Secretary

Ethics \& Clinical Investigations Committee

$\mathrm{NPM} / \mathrm{am}$

$\mathrm{CC} / \mathrm{Dr}$. F. Cummings

Mr. O. Bisbano 
page 216

Leucovorin is similar to folic acid, an essential vitamin normally contained in the diet. It is a drug normally used with methotrexate in cancer chemotherapy. Extemely large amounts have been adminfstered to normal subjects with no ill or toxic effects.

The objective of this research is to study the rate leucovorin is removed from your body and to attempt to determine the amounts of other compounds produced by your body in your blood as a function of time.

Subjects volunteering to participate in this project will be required to abstain from all drugs and alcohol for a period of 48 hours prior to each test. In addition, all volunteers will be required to fast for twelve hours before starting the test and for at least four hours after the test has begun. The drug, Calcium Leucovorin, will be prepared using commercially available intravenous preparations. A low dose ( $10 \mathrm{mg}$ ) of leucovorin will be administered to you directly into your arm vein by a physician using a hypodermic syringe. A catheter (‥e. a small tube) will be placed in the vein of your arm for the collection of blood. Ten milliliters (about two teaspoonfuls) will be collected before you receive the dose of leucovorin and thirteen ten milliliter blood samples will be collected at fifteen minutes, thirty minutes, forty-five minutes, one hour, one and one half hours, two hours, two and one half hours, three bours, four hours, five hours, six hours, seven hours and eight hours after drug administration. blood samples will be drawn by a physician.or appropriately trained personnel. 
page 217

Leucovorin has been reported to be completely free of toxic reactions except for a single report of an allergic reaction to the drug with no lasting ill effects. At the dose of leucovorin you will receive, the risk of any side effect is minimal.

Risks associated with the use of a catbeter for the collection of blood samples include: infection, hematoma (1.e. soreness. and/or "black and blue" mark) or bleeding.

Medical care for problems resulting from this study will be available at Roger Williams General Hospital for emergencies. You will not be compensated for injuries resulting from this study.

You are free to withdraw from participation in this study at any time during the investigation. You will not be identíied in any publication resulting from this work.

Feel free to ask any questions you have about the study and we will be happy to answer them. If you have any additional questions later, Dr. may be contacted through the investigators or by calling 456-2060.

I, stood the above and having been given the opportunity of asking questions regarding the above project now give my informed consent to participation in the study of Leucovorin Pharmacokinetics in Normal Subjects, University of Rhode Island.

Date : : Volunteer: $\therefore, \therefore, 1,1$

Person explaining the study: Principal Investigator: Witness: $1+1+1+\%$ Date: 
All those being considered for involvement in this study will be healthy volunteers between the ages of twenty and fifty with no known hypersensivity to folic acid or its derivatives. Any medical abnormality, which, in the opinion of the medical consultant or investigators, $:$ is likely to complicate the study or add further risk to the subject will result in the subject being excluded from the study. All subjects will be carefully interviewed and pertinent medical information gathered. All participants will be provided with the opportunity of reading and having carefully explained the Informed consent Form. In addition, participants will be provided the opportunity for further questioning of the investigators. Any subject may withdraw from the study at any time during the investigation. Medical care will be provided at Roger Williams General Hospital for medical energencies resulting fran this study. Subjects will receive no compensation for injuries received during this study.

Participants will be required to abstain from all drugs and alcohol for 48 hours prior to the test period. In addition, participants will be required to fast twelve hours before drug adninistration and for at least four hours after drug administration.

All drug administration and blood sarple collection will be under the direction of a physician at Roger Williams General Hospital in Providence, RI.

Calcium leucovorin will be administered intravenously using cormercially available preparations at a dose of $\$ 60 \mathrm{mg}$. Blood samples will be collected immediately before drug administration and at 0.25 , $0.5,0.75,1,1.5,2,2.5,3,4,5,6,7$, and 8 hours after drug administration through an indwelling cathetor. The test will require 
page 219

that ten milliliters of blood be taken at each interval. for a total of 140 milliters from each volunteer for each test. The risk to the subjects from the administration of the drug is judged to be minimal, doses of over $500 \mathrm{mg}$ have been administered to normal subjects with no toxic effects. Risks resulting from the collection of blood include the possibility of infection, hemotoma and scarring. The amount of blood collected in not excessive, this is less than one-third of a pint. 